Supporting Information for

\title{
Diacylfuroxans Are Masked Nitrile Oxides That Inhibit GPX4 Covalently
}

\author{
John K. Eaton, ${ }^{\dagger}$ Richard A. Ruberto,${ }^{\dagger}$ Anneke Kramm, ${ }^{\dagger}$ Vasanthi S. Viswanathan, ${ }^{*, \dagger}$ and \\ Stuart L. Schreiber ${ }^{*,+, \neq}$ \\ †Broad Institute of MIT and Harvard, Cambridge, Massachusetts 02142, United States \\ ‡Department of Chemistry and Chemical Biology, Harvard University, Cambridge, Massachusetts 02138, \\ United States \\ ${ }^{*}$ Corresponding Author \\ Email: vasanthi@broadinstitute.org (V.S.V); stuart_schreiber@harvard.edu (S.L.S.)
}

\section{Table of Contents}

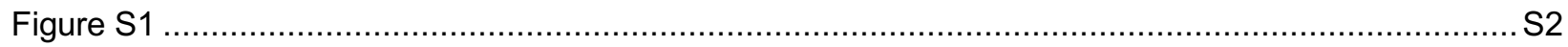

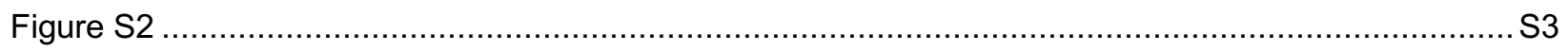

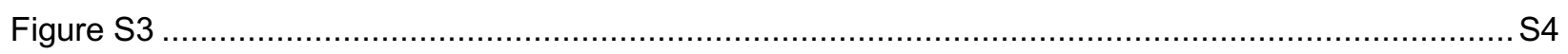

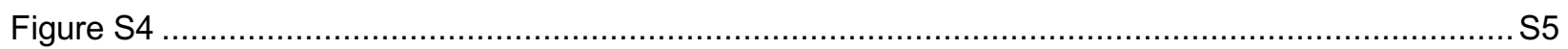

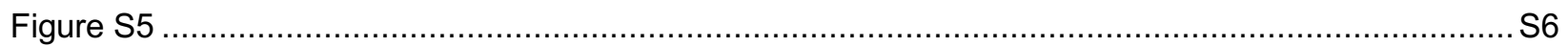

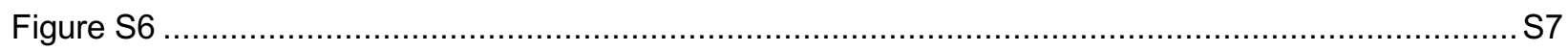

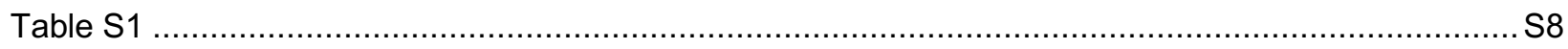

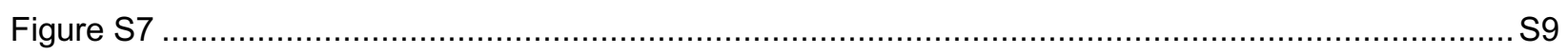

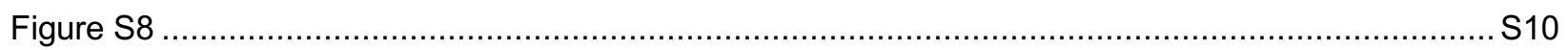

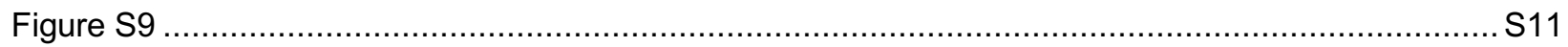

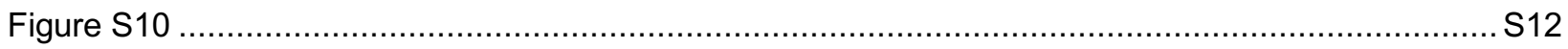

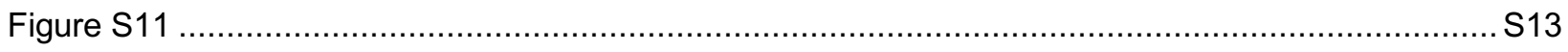

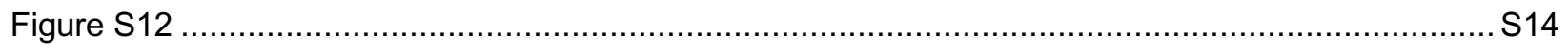

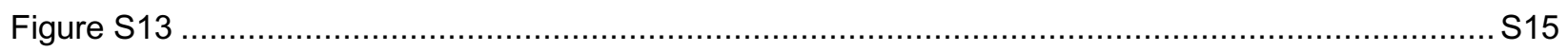

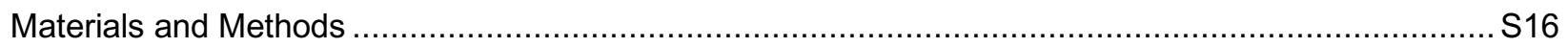

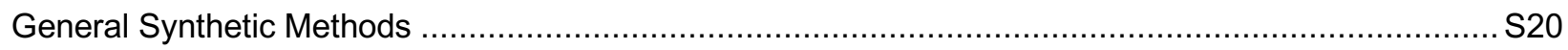

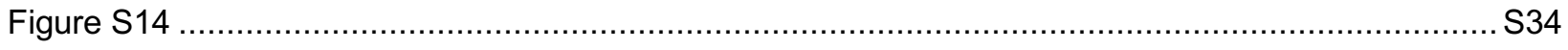

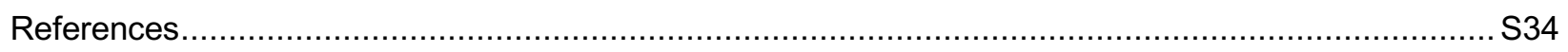

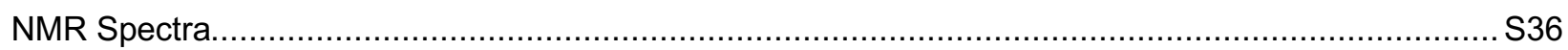




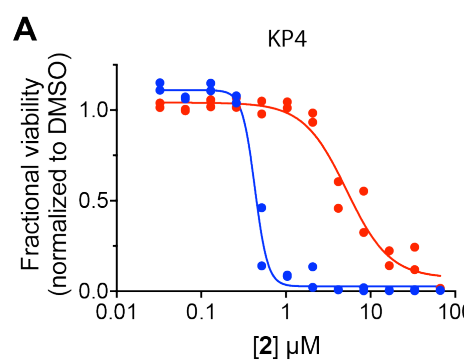

C

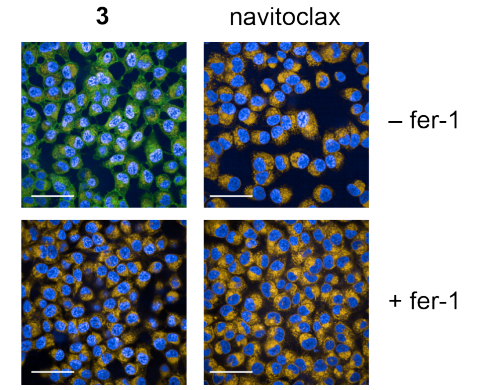

PANC02
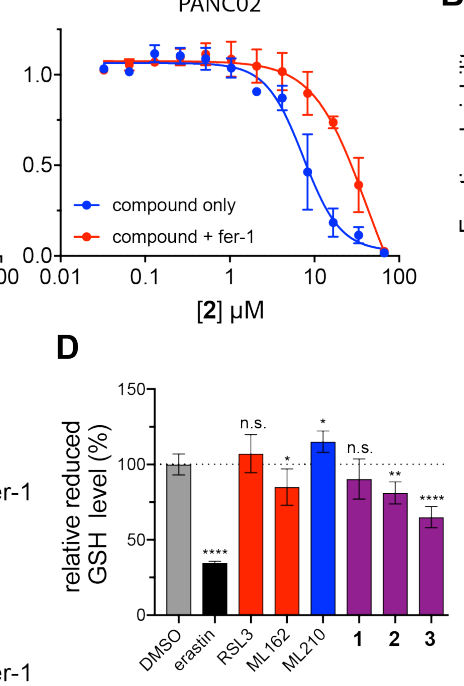

B

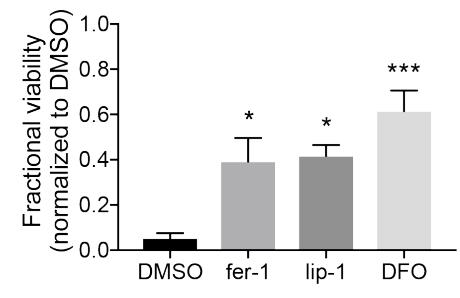

Figure S1: Characterization of diacylfuroxans as ferroptosis inducers. (A) Ferrostatin-1 (fer-1, $1.5 \mu \mathrm{M}$ ) suppresses the cell-killing activity of 2 in human KP4 and mouse PANC02 pancreatic cancer cell lines. EC 50 values for compound only (blue) and compound with fer-1 (red) are indicated in Figure 2C. KP4 data are plotted as two individual technical replicates; PANC02 data are plotted as mean \pm s.e.m., for $n=2$ biologically independent samples measured in duplicate. (B) The cell-killing activity of $2(10 \mu \mathrm{M}, 24 \mathrm{~h})$ is suppressed by the ferroptosis inhibitors fer-1 $(1.5 \mu \mathrm{M})$, liproxstatin-1 (lip-1, $1 \mu \mathrm{M})$, and deferoxamine (DFO, $50 \mu \mathrm{M})$. Data are plotted as mean \pm s.e.m., $\mathrm{n}=4$ technical replicates. ${ }^{*} P<0.05$; ${ }^{* * *} P<0.0005$. All $P$ values determined using one-way ANOVA. (C) Lipid hydroperoxides accumulate in LOX-IMVI cells treated with 1 or $3(10 \mu \mathrm{M}, 90 \mathrm{~min})$ and can be prevented by fer-1 cotreatment $(1.5 \mu \mathrm{M})$ as assessed by C11-BODIPY $581 / 591$ fluorescence in LOX-IMVI cells. Treatment of cells with navitoclax (10 $\mu \mathrm{M}, 90 \mathrm{~min}$ ), which does not induce ferroptotic cell death, does not generate lipid hydroperoxides. Scale bars, $50 \mu \mathrm{m}$. (D) Intracellular reduced glutathione (GSH) levels in LOX-IMVI cells treated with $10 \mu \mathrm{M}$ compound for $90 \mathrm{~min}$ ( $6 \mathrm{~h}$ for erastin). Chloroacetamides are plotted in red and diacylfuroxans in purple. Data are plotted as mean \pm s.d., $n=6$ technical replicates $\left(\mathrm{n}=12\right.$ for DMSO). ${ }^{\star} P<0.05$; ${ }^{* \star} P<0.005$; ${ }^{* * \star \star} P<0.0001$ versus DMSO control. n.s., not significant. All $P$ values determined using one-way ANOVA. 
A

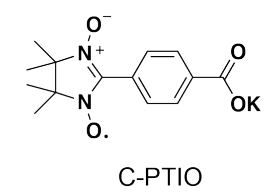

$\mathrm{C}_{\mathrm{M}}$

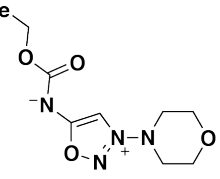

molsidomine

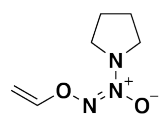

V-PYRRO/NO

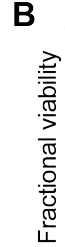

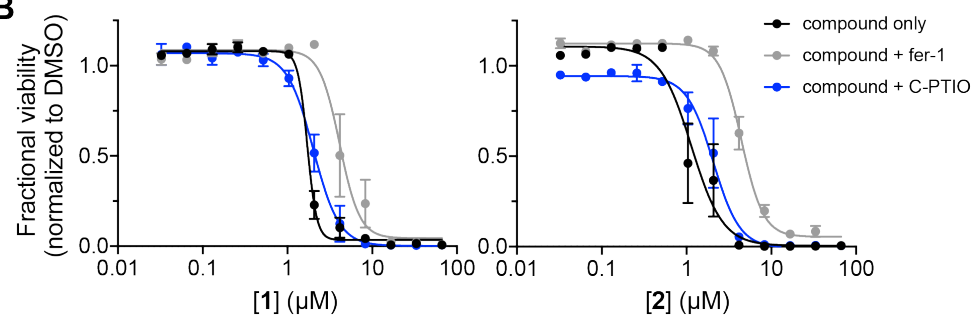

D<smiles>O=C(CCO[N+](=O)[O-])NCCOCCCO</smiles>

nicorandil

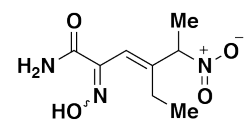

FK409

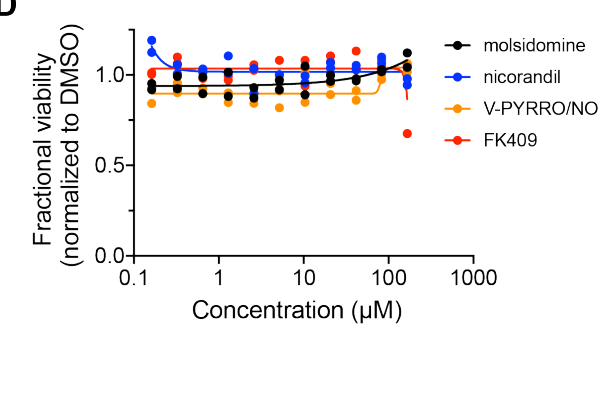

Figure S2: NO donation does not contribute to the ferroptosis-inducing activity of diacylfuroxans. (A) Structure of C-PTIO, a radical nitric-oxide scavenger. ${ }^{1}$ (B) C-PTIO $(50 \mu \mathrm{M})$ does not rescue LOX-IMVI cells from diacylfuroxans 1 (NSC144988) or 2. Data are plotted as mean \pm s.e.m., $n=4$ technical replicates. (C) Structures of commercially-available nitric oxide donors. (E) Small-molecule nitric oxide donors do not induce ferroptotic cell death at concentrations below $150 \mu \mathrm{M}$ in LOX-IMVI cells. Data are plotted as two individual technical replicates. 

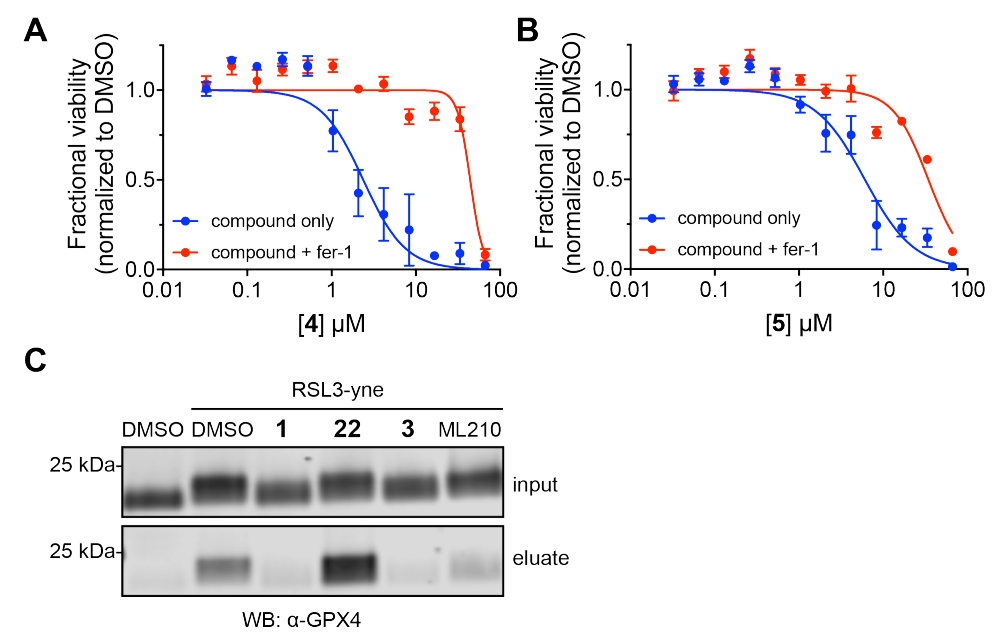

Figure S3: Characterization of diacylfuroxan binding in cells using affinity probe analogs. (A) The cell-killing activity of diacylfuroxan 4 is rescued by fer- $1(1.5 \mu \mathrm{M})$ in LOX-IMVI cells. Data are plotted as mean \pm s.e.m., $n=4$ technical replicates. (B) The cell-killing activity of diacylfuroxan 5 is rescued by fer-1 $(1.5 \mu \mathrm{M})$ in LOXIMVI cells. Data are plotted as mean \pm s.e.m., $n=4$ biological replicates. (C) Western blot of competitive GPX4 pulldown assay showing that treatment of LOX-IMVI cells with diacylfuroxans 1 and $3(20 \mu \mathrm{M}, 1 \mathrm{~h})$ prevents GPX4 enrichment by RSL3-yne (10 $\mu \mathrm{M}, 30 \mathrm{~min})$. An inactive isomer of 2, 4-nitroisoxazole analog 22 (see Figure S9), does not block GPX4 pulldown by RSL3-yne. 
A

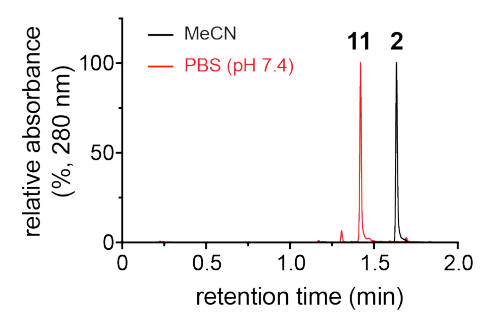

C

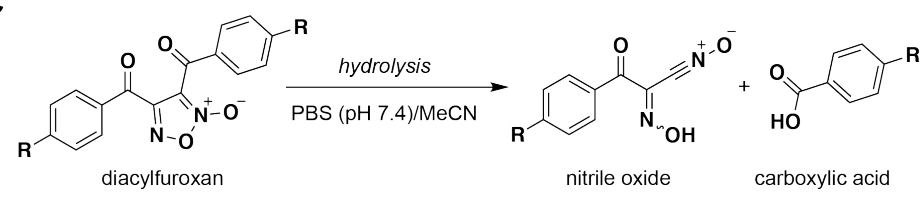

B

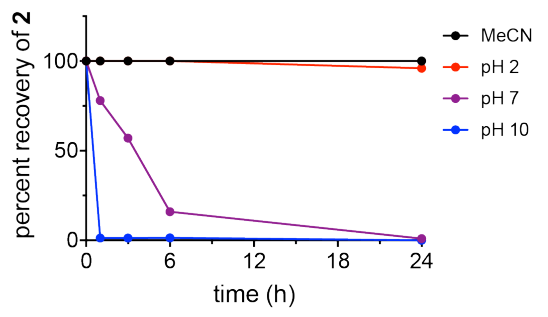
hydrolyzed into nitrile oxide 8 (retention time $=1.41 \mathrm{~min}$ ) after incubation in $\mathrm{PBS}(\mathrm{pH} 7.4) / \mathrm{MeCN}(7: 3)$ at ambient temperature for $4 \mathrm{~h}$. This transformation does not occur when 2 is incubated in $\mathrm{MeCN}$ under otherwise identical conditions. (B) Hydrolysis of $\mathbf{2}$ occurs more rapidly under basic aqueous conditions. Quantification of relative levels of 2 was accomplished by integration of the $280 \mathrm{~nm}$ UV peak at a retention time of $1.63 \mathrm{~min}$. (C) Diacylfuroxans incubated in PBS (pH 7.4)/MeCN (7:3) at ambient temperature for $3 \mathrm{~h}$ are hydrolyzed to yield a nitrile oxide and carboxylic acid. Hydrolysis products were detected by LCMS. 
A

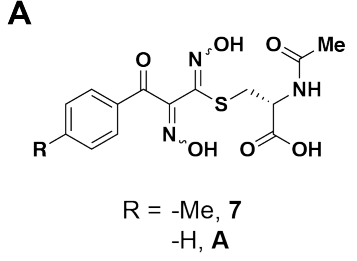

B

\begin{tabular}{ccccc} 
entry & $\begin{array}{c}\text { starting } \\
\text { compound }\end{array}$ & thiol & adduct & $\begin{array}{c}\text { adduct m/z } \\
\text { (ESI-) }\end{array}$ \\
1 & $\mathbf{2}$ & NAC & $\mathbf{7}$ & 366.12 \\
2 & $\mathbf{2}$ & Cys & B & 510.19 \\
3 & $\mathbf{2}$ & GSH & D & 324.17 \\
4 & $\mathbf{8}$ & NAC & $\mathbf{7}$ & 366.18 \\
5 & $\mathbf{8}$ & GSH & D & 510.20 \\
6 & $\mathbf{3}$ & NAC & A & 352.20 \\
7 & $\mathbf{3}$ & Cys & C & 309.91 \\
8 & $\mathbf{3}$ & GSH & E & 496.20 \\
9 & $\mathbf{2 2}$ & NAC & n.d. & n.a. \\
10 & $\mathbf{2 2}$ & GSH & n.d. & n.a. \\
11 & $\mathbf{2 2}$ & Cys & n.d. & n.a. \\
\hline
\end{tabular}

E

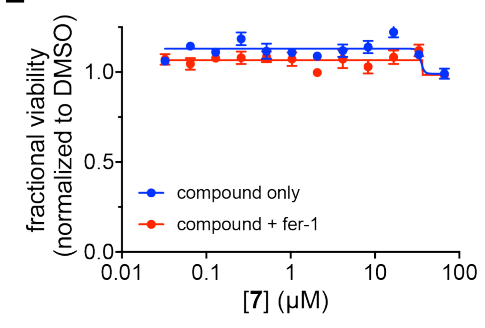

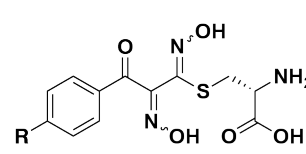

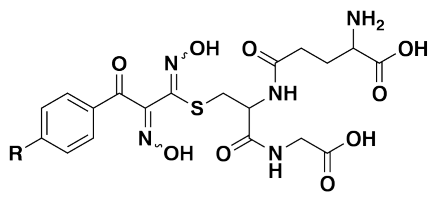

$$
\mathrm{R}=-\mathrm{Me}, \mathbf{B}
$$

$-\mathrm{H}, \mathrm{C}$

C

$-\mathrm{Me}, \mathbf{D}$

$-\mathrm{H}, \mathbf{E}$
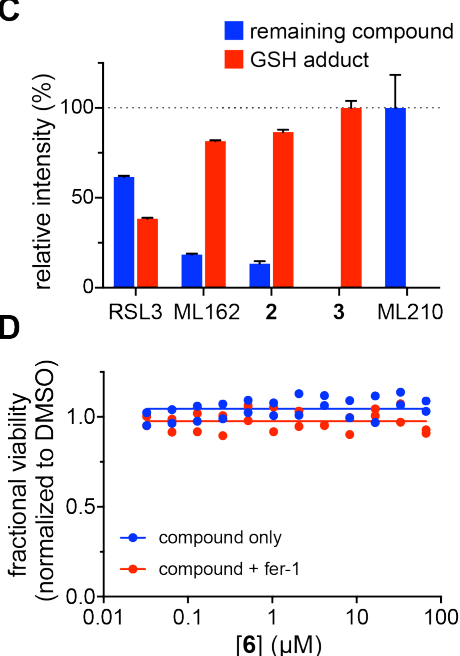

Figure S5: Characterization of diacylfuroxan reactivity with thiols. (A) Structures of adducts formed upon incubation of diacylfuroxans 2 or $3(100 \mu \mathrm{M})$ with thiols $(5 \mathrm{mM})$ in PBS $(\mathrm{pH} 7.4) / \mathrm{MeCN}(7: 3)$. Reactions were incubated at ambient temperature for $16 \mathrm{~h}$. (B) Summary of thiol reactivity studies. Diacylfuroxan 2 and nitrile oxide 8 give rise to identical thiol adducts. Diacylfuroxan 3 also forms similar thiol adducts while the inactive 4-nitroisoxazole 22 (see Figure S9) is unreactive. n.d., not detected. (C) Thiol reactivity of GPX4 inhibitors $(10 \mu \mathrm{M})$ with GSH $(5 \mathrm{mM})$ in PBS $(7.4) / \mathrm{MeCN}(7: 3)$ at ambient temperature for $24 \mathrm{~h}$. Blue bars indicate percent residual starting material remaining and red bars indicate percent GSH adduct formed. Relative levels of starting compounds and GSH adducts was determined by integrating UV chromatogram (210-400 nm) peaks. Upon reaction with GSH, RSL3 and ML162 form thioether adducts via displacement of chloride from their chloroacetamide groups, and diacylfuroxans 2 and $\mathbf{3}$ produce adducts $\mathbf{D}$ and $\mathbf{E}$, respectively. Data are plotted as mean \pm s.d., $n=3$ technical replicates. (D) Thiohydroximate 6 has no effect on LOX-IMVI cell viability. Data are plotted as two individual technical replicates. (E) Thiohydroximate 7 has no effect on LOX-IMVI cell viability. Data are plotted as mean \pm s.e.m., $n=4$ technical replicates. 
A

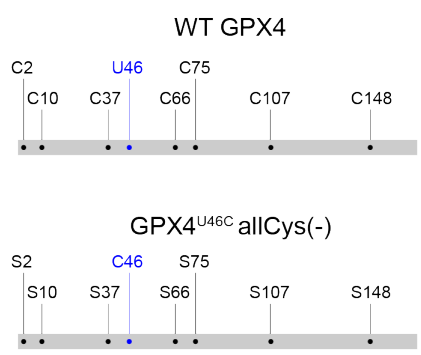

B

\begin{tabular}{ccc} 
compound & $\begin{array}{c}\text { adduct } \\
\text { mass (Da) }\end{array}$ & $\begin{array}{c}\text { fraction } \\
\text { bound (\%) }\end{array}$ \\
\hline 1 & +220 & 10 \\
2 & +204 & 17 \\
3 & +190 & 46 \\
8 & +204 & 48 \\
18 & +196 & 16
\end{tabular}

E

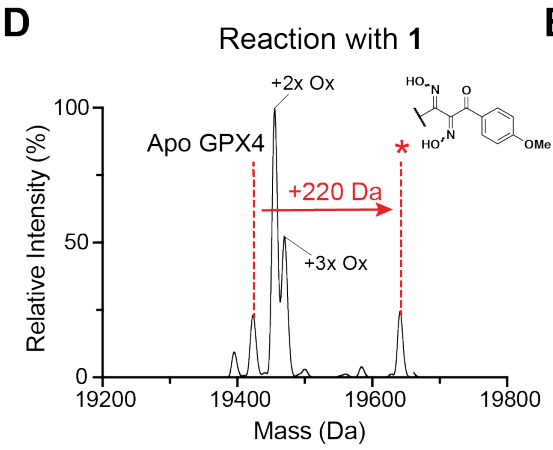

G

Reaction with 18
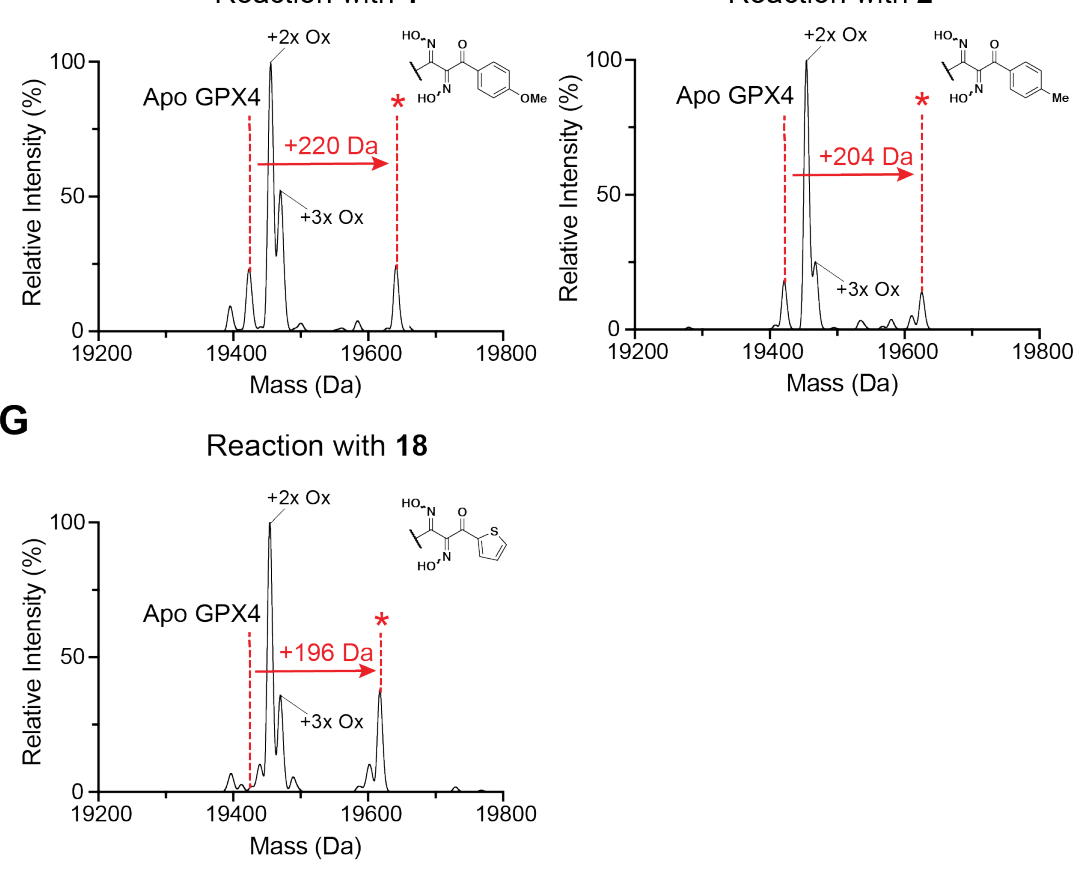

C

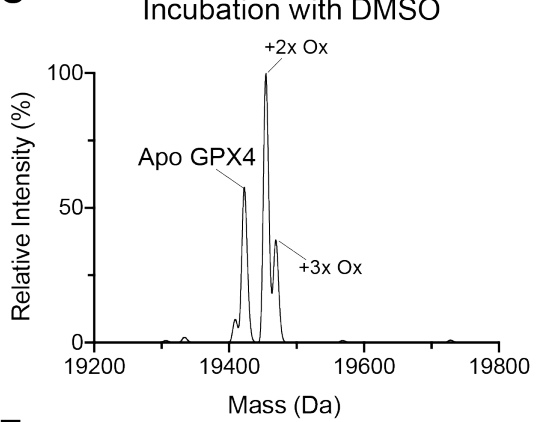

$\mathbf{F}$

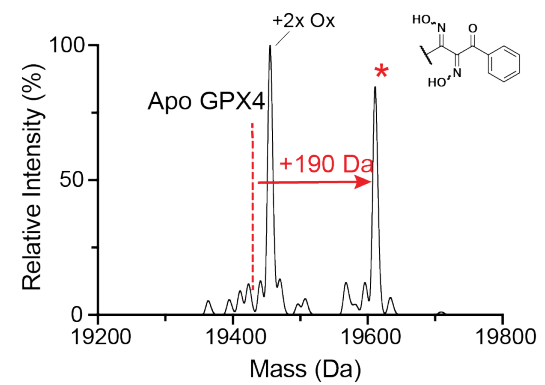

Figure S6: Characterization of diacylfuroxan-derived nitrile oxide adduct formation with purified GPX4 protein. (A) Diagram of WT GPX4 and GPX4 ${ }^{\mathrm{U} 46 \mathrm{C}}$ allCys(-) sequences with the catalytic (seleno)cysteine residue shown in blue. (B) Summary of intact protein binding results. $(C-G)$ Deconvoluted mass spectra of GPX $4^{\mathrm{U} 66 \mathrm{C}}$ allCys(-) after incubation with DMSO (1 vol\%) or the indicated compound $(50 \mu \mathrm{M})$ for $2 \mathrm{~h}$ in PBS (pH 7.4) at ambient temperature. (C) Incubation of the protein without compound results in protein oxidation, likely of the $\mathrm{C} 46$ thiol to sulfinic or sulfonic acid, which prevents the protein from binding inhibitors. (D) The observed 1-derived adduct (+220 Da; upper right) corresponds to the loss of a 4-methoxybenzoyl group from 1. (E) . The observed 2-derived adduct (+204 Da; upper right) corresponds to the loss of a 4methylbenzoyl group. This spectrum is a second independent replicate of the data shown in Figure 4E. $(F)$ The observed 3-derived adduct (+190 Da; upper right) corresponds to the loss of a benzoyl group. (G) The observed 18-derived adduct (+196 Da; upper right) corresponds to the loss of a thiophene-2-carbonyl group. 


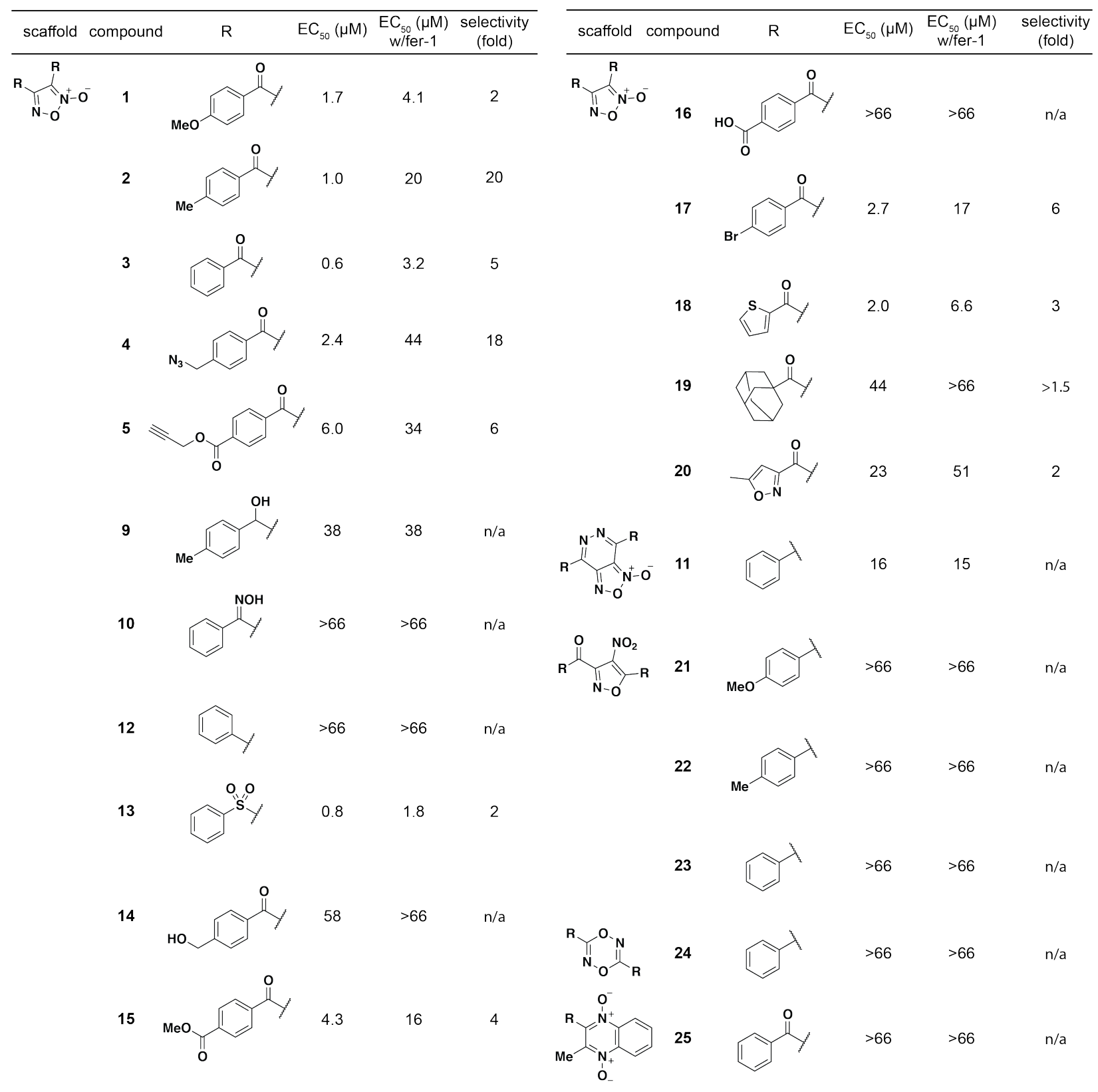

Table S1: Summary of structure-activity relationship (SAR) studies of diacylfuroxans. Cell viability and fer$1(1.5 \mu \mathrm{M})$ rescue experiments were performed in LOX-IMVI cells. EC 50 values were determined from $n \geq$ 2 technical replicates a 12-point dose-response curve. n/a, not applicable. 

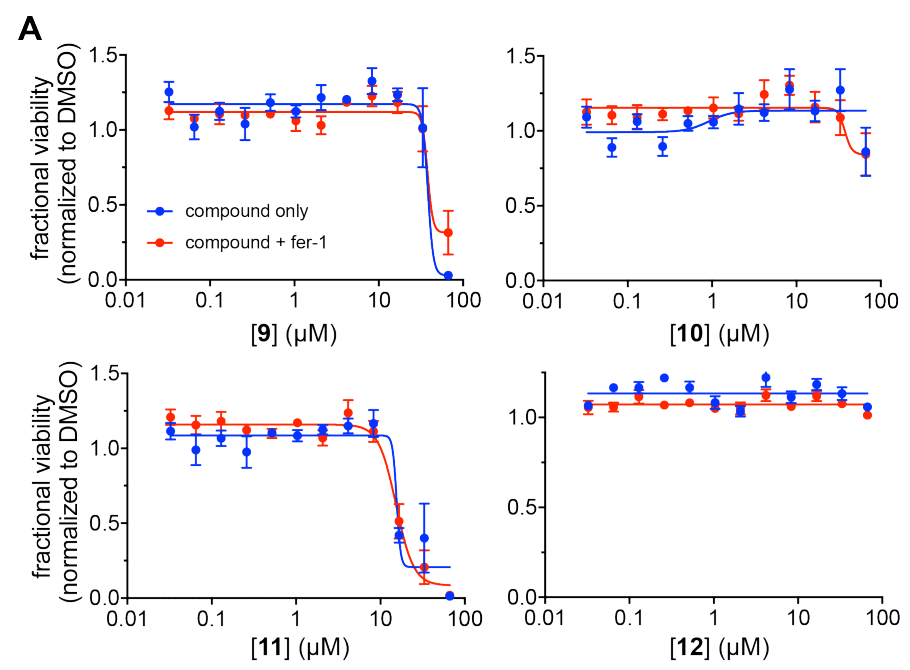

B

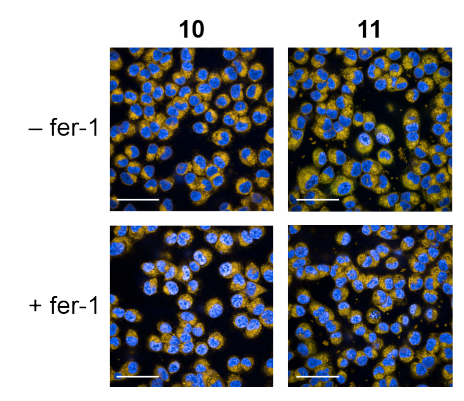

Figure S7: Characterization of furoxan analogs lacking acyl groups. (A) Cell viability and fer-1 (1.5 $\mu \mathrm{M})$ rescue data for analogs 9-12, related to Figures 5A and 5B. Data are plotted as mean \pm s.e.m., $n=4$ technical replicates. (B) Treatment of LOX-IMVI cells with 10 or $11(10 \mu \mathrm{M}, 1 \mathrm{~h})$ does not lead to the accumulation of lipid hydroperoxides according to C11-BODIPY measurements. Scale bars, $50 \mu \mathrm{m}$. 
A

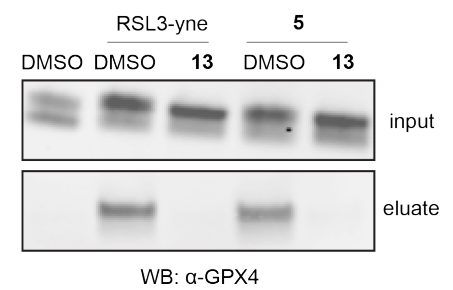

B

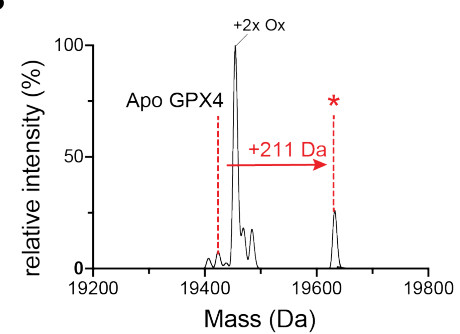

C

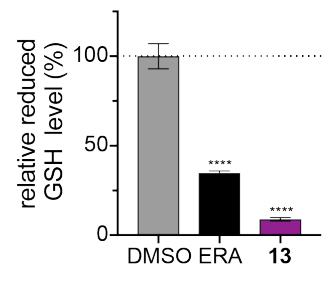

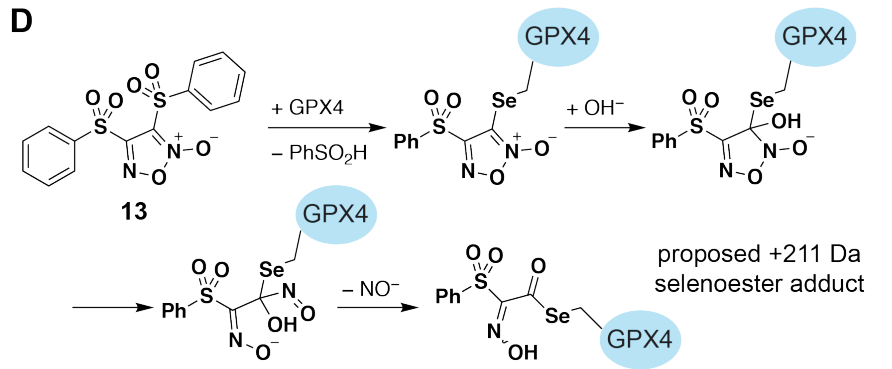

D

$\mathbf{F}$

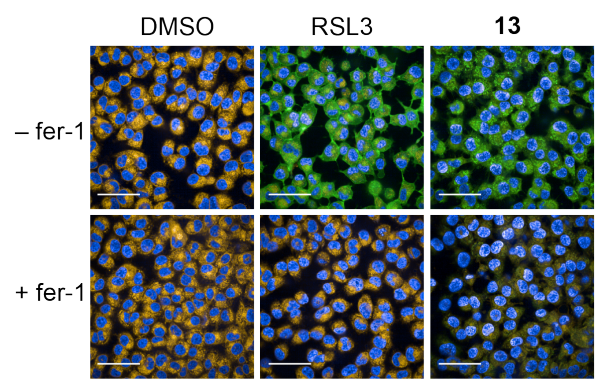

G

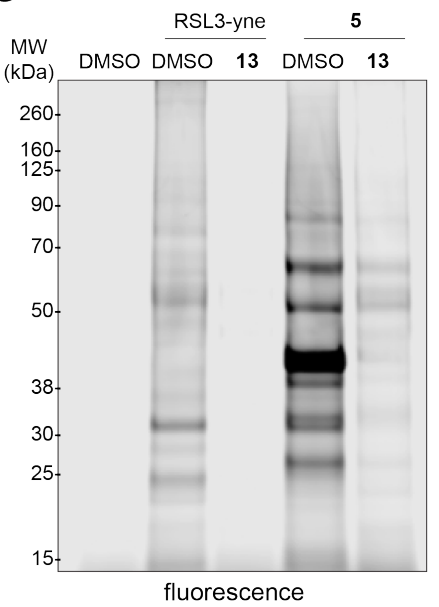

E

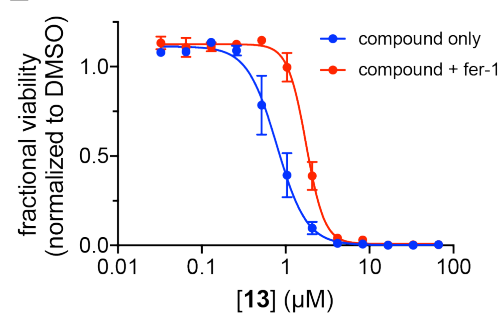

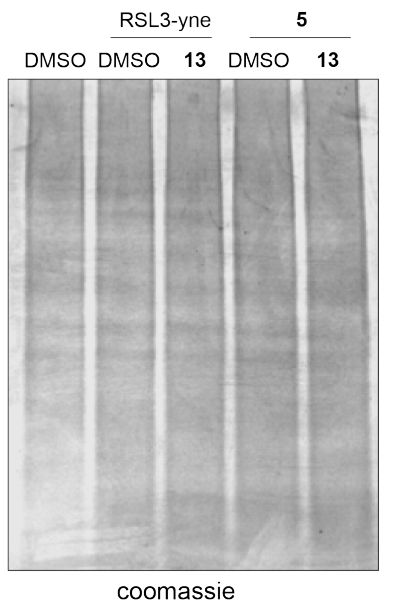

Figure S8: Disulfonylfuroxan 13 binds GPX4 in a manner distinct from that of diacylfuroxans. (A) Pretreatment of LOX-IMVI cells with $13(10 \mu \mathrm{M}, 30 \mathrm{~min})$ prevents GPX4 pulldown by RSL3-yne $(10 \mu \mathrm{M}, 30$ $\min$ ) or $5,(10 \mu \mathrm{M}, 30 \mathrm{~min})$, as assessed by western blot analysis. (B) Deconvoluted mass spectrum of GPX4 ${ }^{46 C}$ allCys(-) after incubation with $13(50 \mu \mathrm{M})$ in PBS (pH 7.4) at ambient temperature for $2 \mathrm{~h}$. (C) Disulfonylfuroxan $13(10 \mu \mathrm{M}, 90 \mathrm{~min})$ depletes levels of intracellular reduced glutathione (GSH) to a greater extent than does erastin (ERA, $10 \mu \mathrm{M}, 6 \mathrm{~h}$ ) in LOX-IMVI cells. Data are plotted as mean \pm s.d., $\mathrm{n}=6$ technical replicates $\left(n=12\right.$ for DMSO). DMSO and erastin data are reproduced from Figure $\mathrm{S} 1 \mathrm{C} .{ }^{* * * *} P<$ 0.0001 versus DMSO control, determined using one-way ANOVA. (D) Proposed mechanism by which 13 could bind GPX4 to yield a +211 Da adduct as observed in (B). (E) Cotreatment with fer-1 (1.5 $\mu \mathrm{M})$ partially rescues the cell-killing effects of 13 in LOX-IMVI cells. Data are plotted as mean \pm s.e.m., $n=4$ technical replicates. (F) Treatment of LOX-IMVI cells with $13(10 \mu \mathrm{M}, 1 \mathrm{~h})$ leads to the accumulation of lipid hydroperoxides as assessed by C11-BODIPY measurements. The C11-BODIPY dye emission shifts from orange to green upon oxidation. Cotreatment with fer-1 $(1.5 \mu \mathrm{M})$ does not fully prevent changes in C11BODIPY emission for 13. Scale bars, $50 \mu \mathrm{m}$. DMSO and RSL3 figures are reproduced from Figure 2D. (G) Pretreatment of LOX-IMVI cells with $13(10 \mu \mathrm{M}, 30 \mathrm{~min})$ suppresses proteome labeling by both RSL3-yne $(10 \mu \mathrm{M}, 30 \mathrm{~min})$ and $\mathbf{5},(10 \mu \mathrm{M}, 30 \mathrm{~min})$ as determined by in-gel fluorescence measurements. Samples are matched with pulldown samples in (A). 
A

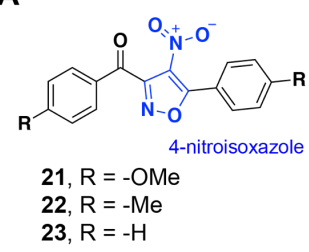

B
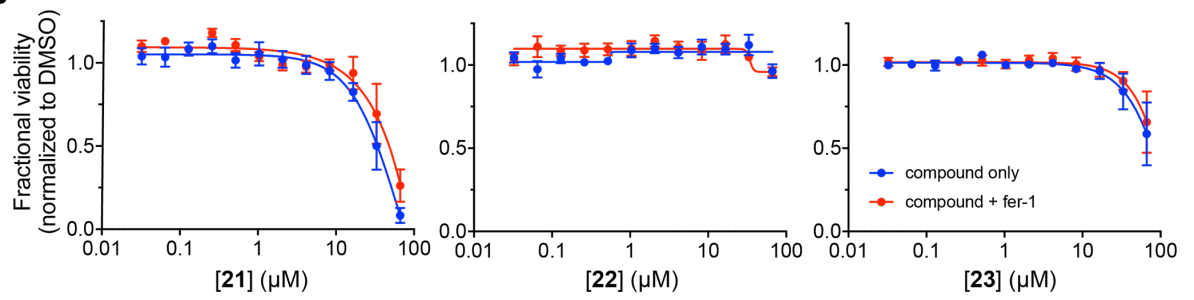

C

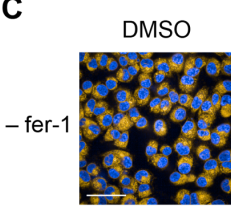

$$
\text { RSL3 }
$$
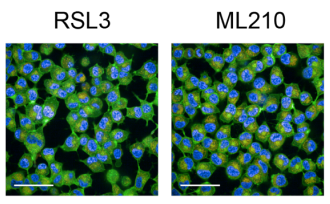

22

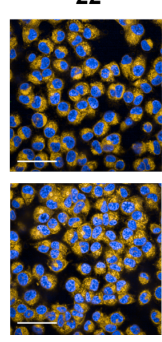

D

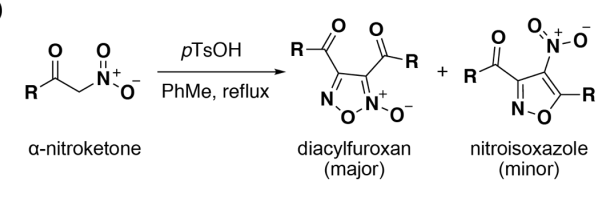

+ fer- 1
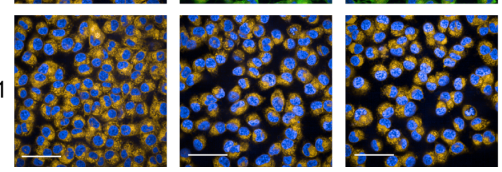

Figure S9: 4-Nitroisoxazoles that are isomeric with diacylfuroxans 1-3 are unable to induce ferroptosis. (A) Structures of 4-nitroisoxazoles 21-23. (B) Nitroisoxazoles 21-23 do not induce ferroptosis based on fer-1 $(1.5 \mu \mathrm{M})$ rescue experiments. Data are plotted as mean \pm s.e.m., $n=4$ technical replicates. (C) Treatment of LOX-IMVI cells with 22 does not generate lipid hydroperoxides as assessed by C11-BODIPY 581/591 fluorescence. Scale bars, $50 \mu \mathrm{m}$. DMSO, RSL3, and ML210 data reproduced from Figure 2D. (D) Scheme depicting the formation of 4-nitroisoxazole byproducts during the synthesis of diacylfuroxans. 
A

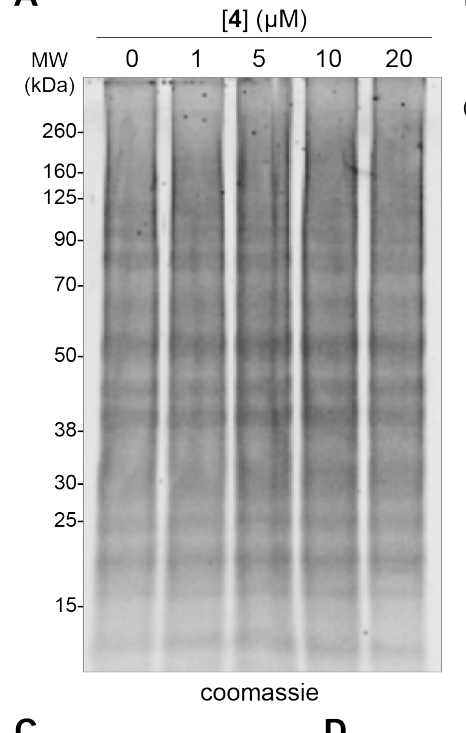

B

B

\begin{tabular}{|c|c|c|c|c|}
\hline \multicolumn{5}{|c|}{$[5](\mu \mathrm{M})$} \\
\hline 0 & 1 & 5 & 10 & 20 \\
\hline
\end{tabular}

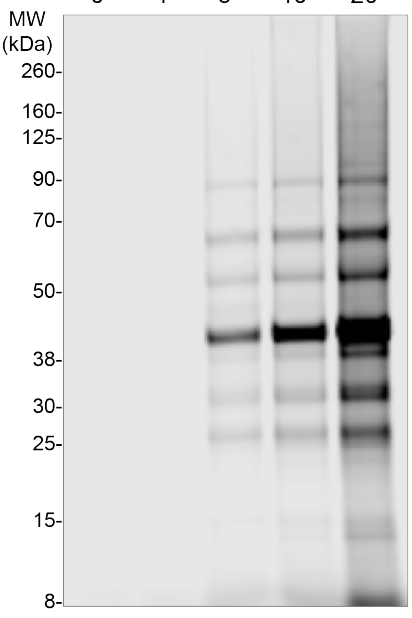

fluorescence

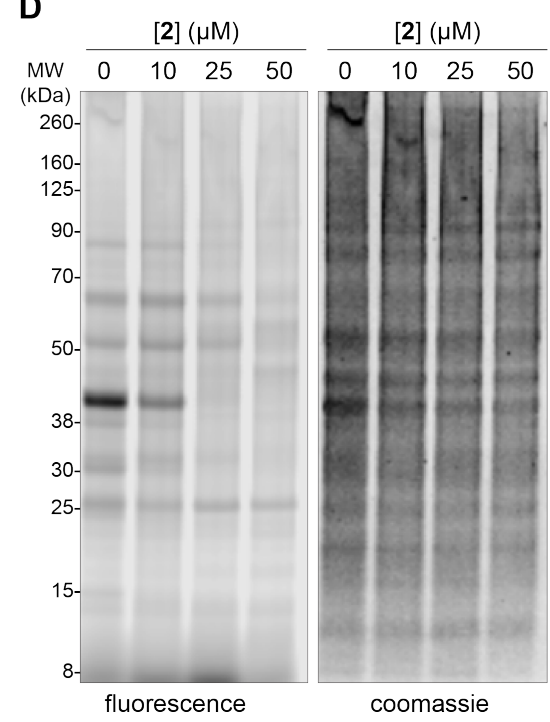

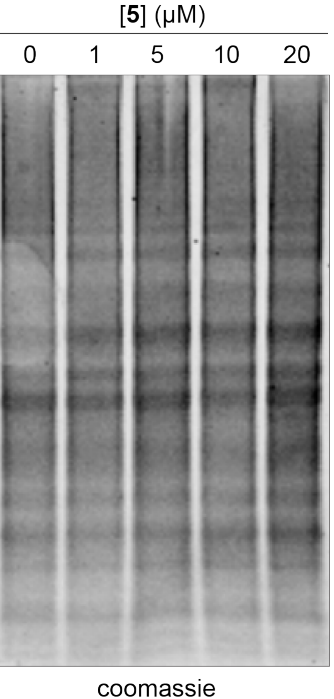

coomassie

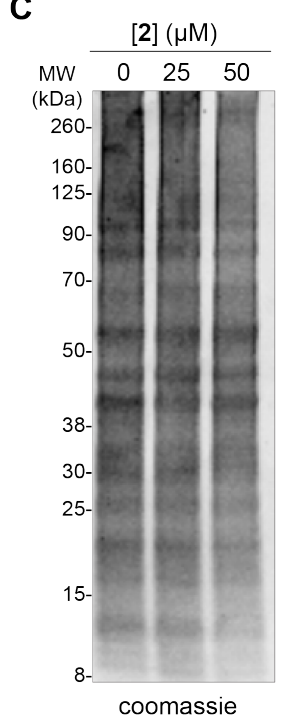

Figure S10: Activity-based protein profiling assessment of diacylfuroxan affinity probes 4 and $\mathbf{5}$. (A) Coomassie-stained gel corresponding to the fluorescence gel in Figure 6A. (B) Assessment of the dosedependent labeling of proteins in LOX-IMVI cells by 5 (1 h treatment). (C) Coomassie-stained gel corresponding to the fluorescence gel in Figure 6B. (D) Treatment of LOX-IMVI cells with 2 (30 min) blocks, in a concentration-dependent manner, the labeling of proteins by $5(5 \mu \mathrm{M}, 30 \mathrm{~min})$. 
A<smiles>C=CCOc1ccc(N(C(=O)CCl)C(C(=O)NCCc2ccccc2)c2ccco2)c(Cl)c1</smiles><smiles>C=CCOc1ccc(C(c2ccc(Cl)cc2)N2CCN(C(=O)c3noc(C)c3[N+](=O)[O-])CC2)cc1</smiles><smiles>O=C(CC(=O)N1CCN(C(O)(c2ccc(Cl)cc2)c2ccc(Cl)cc2)CC1)C(=O)NO</smiles>

B

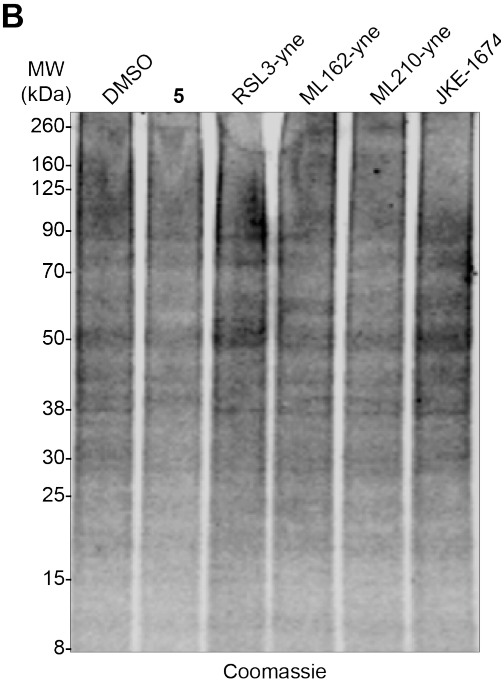

C<smiles>C1CCCCC1</smiles>
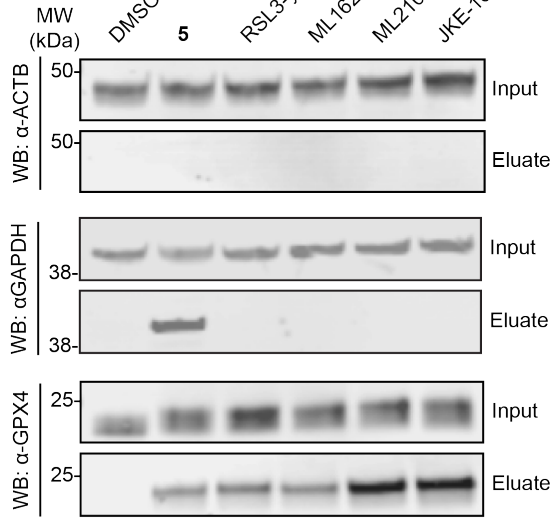

D
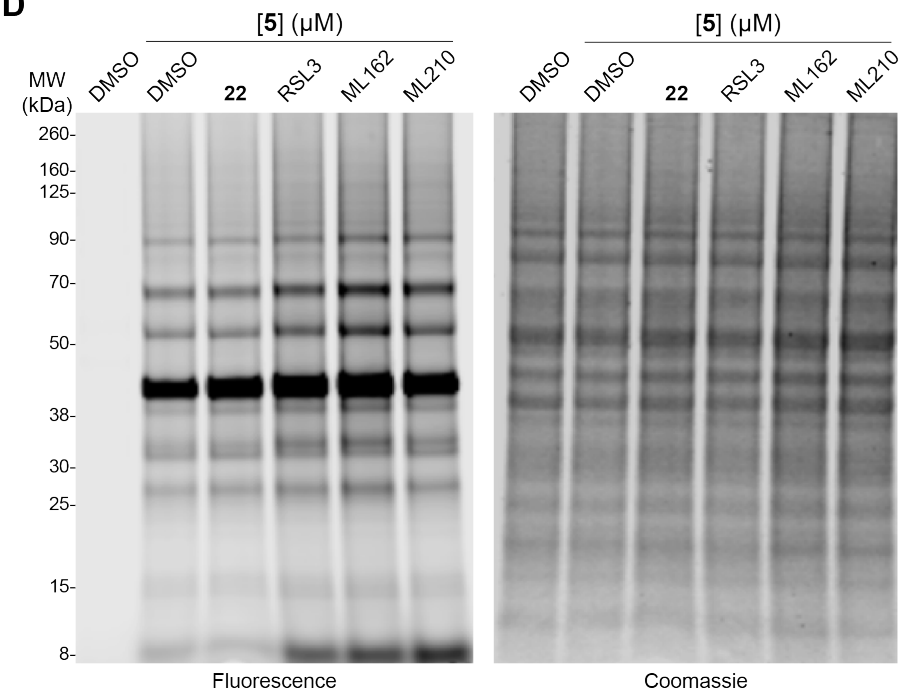

Figure S11: Comparison of the proteome-wide reactivity of diacylfuroxans and other GPX4 inhibitors. (A) Chemical structures of GPX4-inhibitor affinity probes with alkyne groups shown in blue. (B) Coomassiestained gel corresponding to in-gel fluorescence image in Figure 6C. (C) GPX4 is pulled down from LOXIMVI cells treated with the indicated affinity probes $(10 \mu \mathrm{M}, 1 \mathrm{~h})$, as assessed by western blot analysis. Only 5 pulls down GAPDH. Pulldown samples were matched with ABPP experiment in Figure 6C. (D) Pretreatment of LOX-IMVI cells with RSL3, ML162, or ML210 (10 $\mu \mathrm{M}, 30 \mathrm{~min})$ does not compete with proteome labeling by $\mathbf{5}(10 \mu \mathrm{M}, 30 \mathrm{~min})$. These samples are matched with competitive pulldown experiment in Figure 3C. 


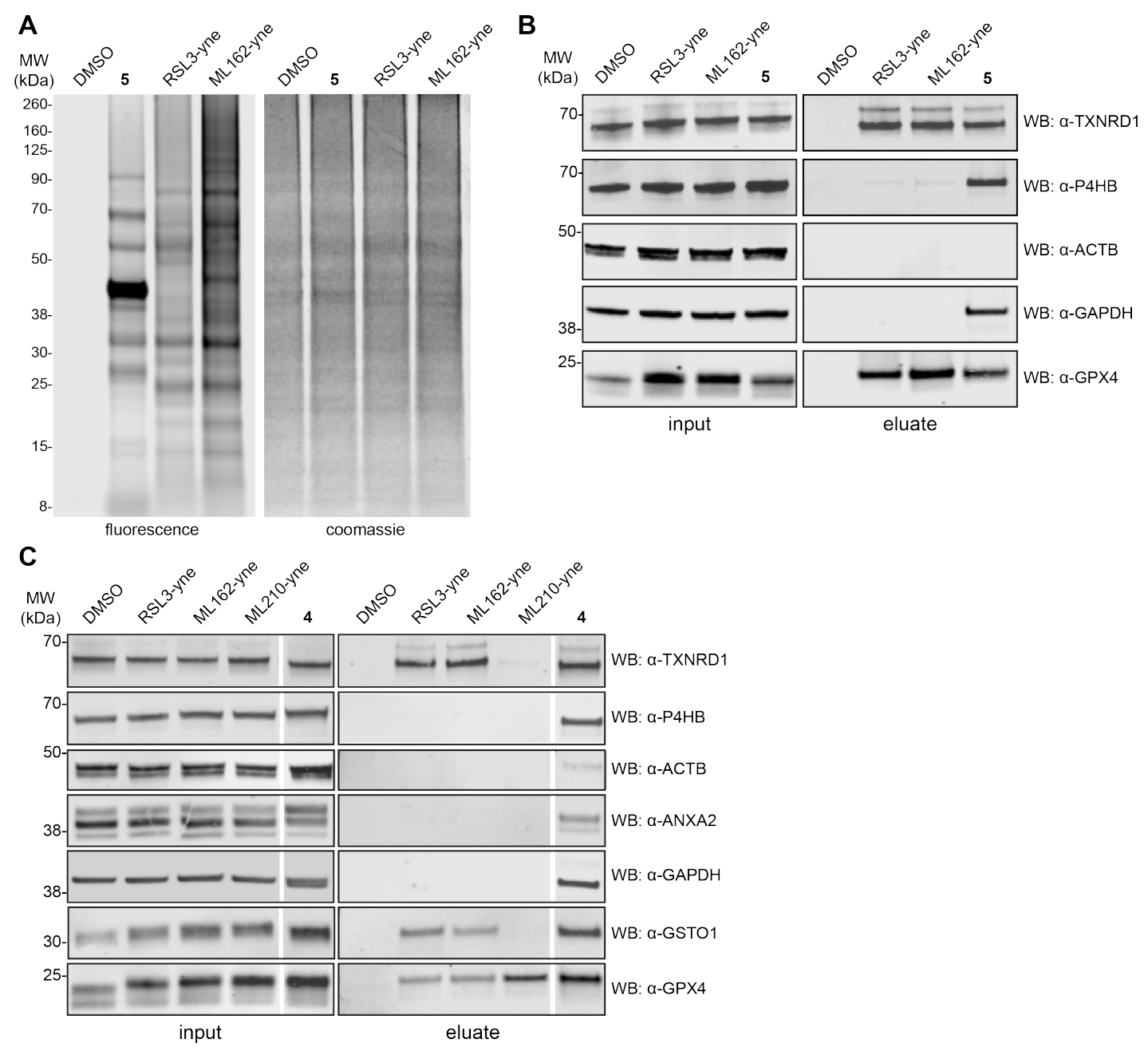

Figure S12: Validation of mass spectrometry-based chemoproteomics assessment of diacylfuroxan 5. (A) Gel-based assessment of proteome-wide labeling of 5, RSL3-yne, and ML162-yne (10 $\mu \mathrm{M}, 1 \mathrm{~h})$. Samples were used for the mass spectrometry-based proteomics experiment summarized in Figure 6D. (B) Western blot analysis using matched samples from Figure S9A confirms that GPX4 was enriched by 5, RSL3-yne, and ML162-yne probes $(10 \mu \mathrm{M}, 1 \mathrm{~h})$. Under these conditions, only 5 strongly enriched GAPDH and P4HB. Eluate data is reproduced from Figure 6E. (C) Diacylfuroxan $4(10 \mu \mathrm{M}, 1 \mathrm{~h})$ pulls down proteins in a manner similar to that of 5 . With the exception of GPX4, ML210-yne $(10 \mu \mathrm{M}, 1 \mathrm{~h})$ does not strongly interact with other proteins examined in western blotting experiments. 


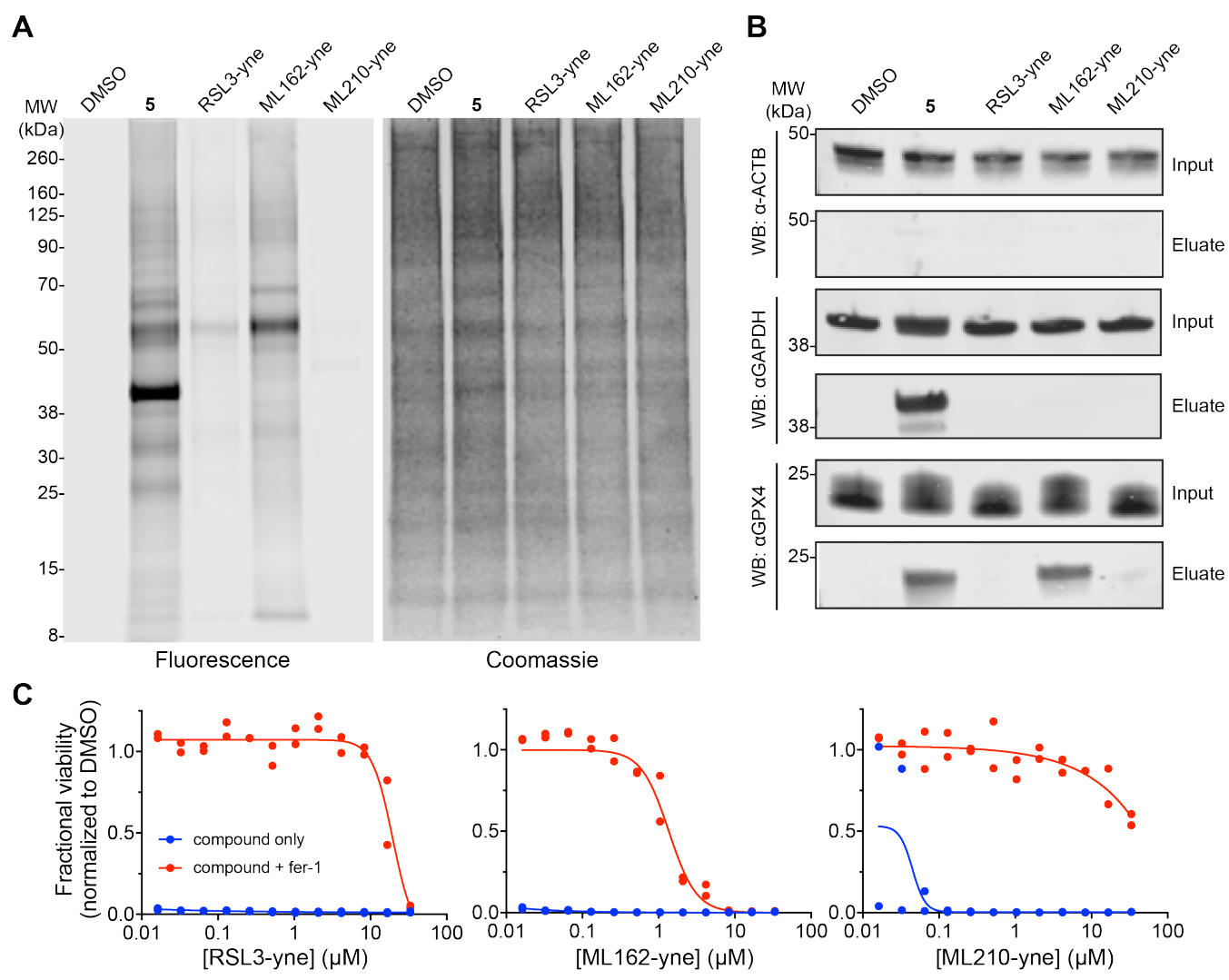

Figure S13: Assessment of diacylfuroxan proteome-wide reactivity in cell lysates. (A) Comparison of cellular reactivity profiles of GPX4-inhibitor probes $(10 \mu \mathrm{M}, 1 \mathrm{~h}$, ambient temperature) in LOX-IMVI cell lysate (2 mg/mL total protein concentration in PBS, $\mathrm{pH} 7.4)$. (B) Western blot analysis of protein affinity enrichment by GPX4-inhibitor probes from LOX-IMVI cell lysate. Samples are matched with the ABPP experiment in (A). (C) Assessment of fer-1 (1.5 $\mu \mathrm{M})$ rescue of RSL3-yne, ML162-yne, and ML210-yne probes in LOX-IMVI cells. Data are plotted as two individual technical replicates. 


\section{MATERIALS AND METHODS}

\section{Cells and reagents}

LOX-IMVI (human melanoma) cells were obtained from the Broad Institute Biological Samples Platform and maintained in RPMI 1640 media (Gibco) supplemented with 10\% FBS (Gibco), 1\% pen-strep (ThermoFisher Scientific), and $5 \mathrm{\mu g} / \mathrm{mL}$ plasmocin (Invivogen). RSL3, ${ }^{3} \mathrm{ML} 162,{ }^{4} \mathrm{ML} 210,{ }^{4,5} \mathrm{JKE}-1674,{ }^{5}$ RSL3-yne, ${ }^{5}$ ML162-yne, ${ }^{5}$ ML210-yne, ${ }^{5}$ and JKE-1674-yne ${ }^{5}$ were synthesized according to reported procedures. Ferrostatin-1 (fer-1), liproxstatin-1 (lip-1), deferoxamine mesylate (DFO), $\mathrm{N}$-acetyl-L-cysteine (NAC), glutathione (GSH), L-cysteine, and erastin were purchased from Sigma Aldrich. BODIPY 581/591 C11 lipid peroxidation sensor and Hoechst 33342 dyes were obtained from ThermoFisher Scientific. DRAQ7 dye was obtained from Abcam. Navitoclax (ABT-263), C-PTIO potassium salt, molsidomine, nicorandil, V-PYRRO/NO, and FK409 were purchased from Cayman Chemical.

\section{Cell viability assays}

Cell viability experiments were performed with LOX-IMVI cells seeded at a density of 1000 cells per well in opaque white 384-well plates (Corning). Cells were allowed to adhere for $24 \mathrm{~h}$ at $37^{\circ} \mathrm{C}$ after which they were exposed to compounds for $72 \mathrm{~h}$. DMSO stock solutions of compounds were added to cells using a CyBio Well Vario liquid handler. Cellular ATP levels were measured using CellTiter-Glo (Promega) as a surrogate for viability. Rescue experiments with ferrostatin-1 (fer-1, $1.5 \mu \mathrm{M}$ ), liproxstatin-1 (lip-1, $1 \mu \mathrm{M}$ ), deferoxamine mesylate (DFO, $50 \mu \mathrm{M})$, and C-PTIO $(50 \mu \mathrm{M})$ were performed using the indicated concentration of rescue agent added to cells and media at the time of seeding.

\section{Lipid peroxidation assay}

LOX-IMVI cells were seeded at a density of 5,000 cells per well in a CellCarrier Ultra 96-well plate (PerkinElmer) in $150 \mu \mathrm{L}$ of RPMI medium supplemented with $10 \%$ FBS, $1 \%$ pen-strep, and $1.5 \mu \mathrm{M}$ fer-1 (where indicated). Cells were allowed to adhere for $24 \mathrm{~h}$ at $37^{\circ} \mathrm{C}$ and then treated with the indicated compounds or DMSO for 90 min at $37^{\circ} \mathrm{C}$. During the last 30 min of incubation, $60 \mathrm{nM}$ DRAQ7, $1 \mu \mathrm{g} / \mathrm{mL}$ Hoechst 33342, and $1 \mu \mathrm{M}$ BODIPY 581/591 C11 dyes were added to the wells. Cells were imaged using an Opera Phenix High-Content Screening System (Perkin-Elmer) equipped with $405 \mathrm{~nm}, 488 \mathrm{~nm}, 560 \mathrm{~nm}$, and $647 \mathrm{~nm}$ lasers. Image analysis was performed with Harmony High-Content Imaging and Analysis software (PerkinElmer).

\section{Cellular glutathione measurements}

LOX-IMVI cells were seeded at a density of 5,000 cells per well in a Costar 3917 96-well plate (Corning) in $150 \mu \mathrm{L}$ of RPMI medium supplemented with $10 \%$ FBS and $1 \%$ pen-strep. Cells were allowed to adhere for $24 \mathrm{~h}$ at $37^{\circ} \mathrm{C}$ after which they were exposed to compounds $(10 \mu \mathrm{M})$ in fresh media $(150 \mu \mathrm{L})$. Cells were incubated with compounds at $37{ }^{\circ} \mathrm{C}$ for the indicated times. Assessment of cellular levels of reduced glutathione (GSH) was performed using the GSH/GSSG-Glo Assay (Promega) according to the kit instructions.

\section{Compound thiol reactivity assay}

The reactivity of compounds towards various thiols was monitored by UPLC-MS. Compound stock solutions in DMSO $(5 \mu \mathrm{L}, 20 \mathrm{mM})$ were diluted in $1 \mathrm{~mL}$ PBS $(\mathrm{pH} 7.4)$ /acetonitrile (7:3) containing $5 \mathrm{mM}$ glutathione (GSH), $\mathrm{N}$-acetyl-L-cysteine (NAC), or L-cysteine (Cys) (0.1 mM final test compound, 50 -fold excess thiol). Samples were vortexed and stored in the dark overnight at ambient temperature. Reactions ( $1 \mu \mathrm{L}$ injections) were monitored using an Acquity UPLC coupled to a SQ2 MS (Waters) operating in both positive and negative electrospray ionization modes. An Acquity BEH C18 column (1.7 um, 2.1 x $50 \mathrm{~mm}$, Waters) was used with column temperature maintained at $45^{\circ} \mathrm{C}$. Mobile phases consisted of $0.01 \%$ formic acid in water (eluent $\mathrm{A}$ ) and $0.01 \%$ formic acid in acetonitrile (eluent $\mathrm{B}$ ). The following gradient was run at a flow rate of $0.65 \mathrm{~mL} / \mathrm{min}:$ 0-0.3 $\min 3-4 \% \mathrm{~B}, 0.3-1.5 \min 4-95 \% \mathrm{~B}, 1.5-1.9 \min 95 \% \mathrm{~B}, 1.9-2.0 \min 5 \% \mathrm{~B}$. 


\section{Compound pH stability assay}

Solution stability of compounds was determined by UPLC-UV. Compound stock solutions in DMSO $(5 \mu \mathrm{L}$, $20 \mathrm{mM}$ ) were diluted in $1 \mathrm{~mL}$ of the respective aqueous reaction buffer $(\mathrm{pH} \mathrm{2,7}$, and 10) and incubated at ambient temperature. Reaction buffers consisted of $0.1 \mathrm{M}$ hydrochloric acid-potassium chloride $(\mathrm{pH} 2), 0.1$ $\mathrm{M}$ sodium phosphate $(\mathrm{pH} 7)$, and $0.1 \mathrm{M}$ sodium bicarbonate-sodium carbonate $(\mathrm{pH} 10)$. Samples were monitored by UPLC-UV (Waters Acquity equipped with photodiode array detector) immediately after mixing $(t=0)$ and then again at $1,3,6$, and $24 \mathrm{~h}$. The percent recovery of a compound was determined by comparing relative UV peak areas at $280 \mathrm{~nm}$. Chromatography conditions were identical to those described for thiol reactivity assays.

\section{GPX4 pulldown assay}

Direct and competitive GPX4 affinity enrichment experiments were performed as previously described. ${ }^{5}$ For binding experiments in intact cells, LOX-IMVI cells were seeded in 6-well plates in RPMI medium (supplemented with 10\% FBS and 1\% pen-strep) and grown until they reached a confluency of $70-80 \%$. For competition experiments, unlabeled competitor compounds $(10 \mathrm{mM}$ stocks in DMSO, final concentration $=10 \mu \mathrm{M}$ ) or DMSO were added to the appropriate wells and incubated for $30 \mathrm{~min}$ at $37^{\circ} \mathrm{C}$. RSL3-yne $(10 \mathrm{mM}$ stocks in DMSO, final alkyne concentration $=10 \mu \mathrm{M})$ was added to the cells and incubated for an additional $30 \mathrm{~min}$ at $37^{\circ} \mathrm{C}$. For direct pulldown experiments with alkyne- or azide-labeled compounds, cells were treated for $1 \mathrm{~h}$ probe. Media was removed and cells were washed once with PBS ( $\mathrm{pH}$ 7.4). Cells were collected after incubation with trypsin-EDTA (Gibco), pelleted, and washed twice with PBS (pH 7.4). Cell lysis was performed in Lysis Buffer (PBS containing 1\% Triton X-100 and Roche Complete protease inhibitors) for $20 \mathrm{~min}$ on ice. Samples were cleared by centrifugation $\left(20,000 \times \mathrm{g}, 4^{\circ} \mathrm{C}\right)$. Total protein content of lysates was assessed with a Bradford assay kit (ThermoFisher Scientific) and adjusted to $2 \mathrm{mg} / \mathrm{mL}$. Lysate-based binding experiments were performed by treating LOX-IMVI cell lysate ( $2 \mathrm{mg} / \mathrm{mL}$ total protein concentration prepared in Lysis Buffer) with the indicated compounds for $1 \mathrm{~h}$ at ambient temperature.

Lysates were then subjected to copper-catalyzed azide-alkyne cycloaddition (CuAAC) conditions with azide-PEG3-biotin conjugate ('biotin-azide', Sigma Aldrich) or biotin-PEG4-alkyne ('biotin-alkyne', Sigma Aldrich) for alkyne-containing or azide-containing probes, respectively. Typical reactions were performed with a final volume of $120 \mu \mathrm{L}$ consisting of $100 \mu \mathrm{L}$ lysate $(2 \mathrm{mg} / \mathrm{mL}$; final concentration $=1.67 \mathrm{mg} / \mathrm{mL}), 2.4$ $\mu \mathrm{L}$ SDS (10\%; final concentration $=0.2 \%), 2.4 \mu \mathrm{L}$ azide- or alkyne-biotin conjugate ( $5 \mathrm{mM}$ in DMSO; final concentration $=100 \mu \mathrm{M}$ ), and $15.2 \mu \mathrm{L}$ of Catalyst Mix (final concentration $=1.3 \mathrm{mM} \mathrm{Cu}_{2} \mathrm{SO}_{4}, 1.3 \mathrm{mM} \mathrm{TCEP}$, and $75 \mu \mathrm{M}$ TBTA). The Catalyst Mix stock was prepared by mixing 3 parts TBTA ( $1 \mathrm{mM}$ in 1:4 $\mathrm{DMSO} / \mathrm{tBuOH}), 1$ part $50 \mathrm{mM} \mathrm{Cu}_{2} \mathrm{SO}_{4}$ in water, and 1 part TCEP $(50 \mathrm{mM}$ in water, $\mathrm{pH} 7.0)$ immediately before use. After addition of all components, CuAAC reactions were vortexed and allowed to react for $1 \mathrm{~h}$ at ambient temperature and then diluted with $120 \mu \mathrm{L} 0.2 \%$ SDS in PBS. A $40 \mu \mathrm{L}$ aliquot was removed and quenched with 6x SDS sample buffer (Boston Bio Products, reducing) as an input control. Pierce highcapacity streptavidin agarose beads (ThermoFisher Scientific) were added to the remaining sample and rotated overnight at $4{ }^{\circ} \mathrm{C}$. Beads were then separated by centrifugation and washed sequentially with $1 \%$ SDS $(3 \times 1 \mathrm{~mL})$ and PBS $(2 \times 1 \mathrm{~mL})$. Proteins were eluted by boiling the beads in $75 \mu \mathrm{L}$ of $2 \times$ SDS sample buffer for 10 minutes. The supernatant was removed (eluate sample) and analyzed by SDS-PAGE and western blotting.

\section{Western blot analysis}

Samples for western blot analysis (typically $30 \mu \mathrm{g}$ protein) were heated to $95^{\circ} \mathrm{C}$ for 5 min prior to separation by SDS/PAGE on NuPAGE $4-12 \%$ Bis-Tris gels (ThermoFisher Scientific). Samples were transferred to a nitrocellulose membrane using an iBlot 2 Gel Transfer Device (ThermoFisher Scientific) and blocked with Odyssey blocking buffer in PBS (LI-COR BioSciences) for $1 \mathrm{~h}$ at room temperature. Proteins were visualized with the following primary antibodies: annexin A2 (ANXA2, ab41803, Abcam); actin, cytoplasmic 1 (ACTB, sc-47778, SCBT); glyceraldehyde 3-phosphate dehydrogenase (GAPDH D16H11, 5175, Cell Signaling Technology); glutathione peroxidase 4 (GPX4, ab41787, Abcam, lot\# GR3226161-2); glutathione S-transferase omega 1 (GSTO1, ab129106, Abcam); protein disulfide-isomerase (P4HB, ab3672, Abcam); thioredoxin reductase 1 (TXNRD1, ab151716, Abcam). All primary antibodies were used at a 1:1000 dilution in Odyssey blocking buffer in PBS (LI-COR BioSciences) and incubated overnight at $4{ }^{\circ} \mathrm{C}$. Blots were then 
washed with tris-buffered saline (pH 7.4) with 1\% Tween-20 (TBST, 3 × $5 \mathrm{~min}$ ). IRdye donkey anti-rabbit 800CW (926-32213, LI-COR Biosciences) and IRdye donkey anti-mouse 680RD (926-68072, LI-COR Biosciences) secondary antibodies were used at 1:10,000 dilution and incubated with blots for $1 \mathrm{~h}$ at room temperature. Blots were washed with TBST $(3 \times 5 \mathrm{~min})$ and visualized with an Odyssey imaging system (LI-COR BioSciences).

\section{Proteome reactivity profiling}

Assessment of probe proteome-wide reactivity was performed as described previously. ${ }^{5}$ For determination of cellular probe reactivity in LOX-IMVI cells, probe-treated lysates were prepared as described above for the "GPX4 pulldown assay". For lysate reactivity experiments, untreated LOX-IMVI cells were lysed in Lysis Buffer (PBS containing 1\% Triton X-100 and Roche Complete protease inhibitors) for 20 min on ice. Samples were cleared by centrifugation $\left(20,000 \times \mathrm{g}, 4^{\circ} \mathrm{C}\right)$. Total protein content of lysates was assessed with a Bradford assay kit (ThermoFisher Scientific) and adjusted to $2 \mathrm{mg} / \mathrm{mL}$. Lysates were incubated with $10 \mu \mathrm{M}$ of the indicated probe for $1 \mathrm{~h}$ at ambient temperature. Lysate-based reactivity profiling experiments were performed by treating $2 \mathrm{mg} / \mathrm{mL}$ LOX-IMVI lysate (prepared in Lysis Buffer) with the indicated compounds for $1 \mathrm{~h}$ at ambient temperature.

Lysates were subjected to CuAAC conditions with IRDye 680RD Azide (LI-COR BioSciences, 92960005) or IRDye 680RD Alkyne (LI-COR BioSciences, 929-60006) for alkyne-containing or azidecontaining probes, respectively. Typical reactions were performed with a final volume of $60 \mu \mathrm{L}$ consisting of $50 \mu \mathrm{L}$ lysate $(2 \mathrm{mg} / \mathrm{mL}$; final concentration $=1.67 \mathrm{mg} / \mathrm{mL}), 1.2 \mu \mathrm{L} \mathrm{SDS}(10 \%$; final concentration $=0.2 \%)$, $1.8 \mu \mathrm{L}$ azide- or alkyne-biotin conjugate $(1 \mathrm{mM}$ in DMSO; final concentration $=30 \mu \mathrm{M})$, and $7.0 \mu \mathrm{L}$ of Catalyst Mix (final concentration $=1.2 \mathrm{mM} \mathrm{Cu}_{2} \mathrm{SO}_{4}, 1.2 \mathrm{mM}$ TCEP, and $70 \mu \mathrm{M}$ TBTA). The Catalyst Mix stock was prepared by mixing 3 parts TBTA ( $1 \mathrm{mM}$ in 1:4 DMSO/tBuOH), 1 part $50 \mathrm{mM} \mathrm{Cu}_{2} \mathrm{SO}_{4}$ in water, and 1 part TCEP (50 mM in water, $\mathrm{pH} 7.0$ ) immediately before use. After addition of all components, CuAAC reactions were vortexed and allowed to react for $1 \mathrm{~h}$ at ambient temperature protected from light. Reactions were then quenched by addition of $-20^{\circ} \mathrm{C}$ acetone $(500 \mu \mathrm{L})$, vortexed, and stored at $-20^{\circ} \mathrm{C}$ overnight. The precipitated proteins were pelleted by centrifugation $\left(20,000 \times \mathrm{g}, 10 \mathrm{~min}, 4^{\circ} \mathrm{C}\right)$ and the liquid was removed. Protein pellets were washed with $-20^{\circ} \mathrm{C}$ methanol $(2 \times 500 \mu \mathrm{L})$ by briefly sonicating (bath sonicator) to fully resuspend and subsequent pelleting by centrifugation $\left(20,000 \times \mathrm{g}, 5 \mathrm{~min}, 4^{\circ} \mathrm{C}\right)$. Liquid was completely removed from the pellets and the samples were allowed to air dry for $10 \mathrm{~min}$. SDS sample buffer (2x, 100 $\mu \mathrm{L}$ ) was added and samples were heated at $95{ }^{\circ} \mathrm{C}$ for $10 \mathrm{~min}$. Samples were separated by SDS-PAGE (Bolt 4-12\% Bis-tris plus, 200V). In-gel fluorescence was measured in the $700 \mathrm{~nm}$ channel of the LI-COR Odyssey. The gel was then Coomassie stained (InstantBlue, Expedeon) and imaged to confirm equivalent protein loading.

\section{Mass spectrometry-based proteomics}

Probe labeling of LOX-IMVI cells, click chemistry, and streptavidin enrichment of probe-labeled proteins Samples were prepared by treating LOX-IMVI cells (T175 flask, $90 \%$ confluent) with alkyne probe $(10 \mu \mathrm{M})$ for $1 \mathrm{~h}$ at $37^{\circ} \mathrm{C}$. Growth media was removed from the flasks and cells were then washed with PBS (pH 7.4). Cells were collected after incubation with trypsin-EDTA, pelleted, and washed twice with PBS (pH 7.4). Cells were lysed in Lysis Buffer as descried previously and lysate protein concentration was normalized to $2 \mathrm{mg} / \mathrm{mL}$ in a volume of $4 \mathrm{~mL}(\sim 8 \mathrm{mg} / \mathrm{mL}$ total protein per condition). Click chemistry was performed by adding SDS $(10 \%, 96 \mu \mathrm{L})$, biotin-azide $(5 \mathrm{mM}, 96 \mu \mathrm{L})$, and Catalyst Mix $(608 \mu \mathrm{L})$ with brief vortexing after the addition of each component. Reactions were rotated end-over-end for $1.5 \mathrm{~h}$ at ambient temperature. Methanol/chloroform precipitation was performed to remove excess click chemistry reagents from the reactions. Ice-cold methanol $(20 \mathrm{~mL})$, ice-cold chloroform $(5 \mathrm{~mL})$, and ice-cold water $(15 \mathrm{~mL})$ was added to the reactions with vortexing. Samples were centrifuged $\left(4300 \times \mathrm{g}, 4^{\circ} \mathrm{C}, 15 \mathrm{~min}\right)$ and the protein pellet was collected. The protein pellet was washed twice with $15 \mathrm{~mL}$ ice-cold methanol and redissolved in $2.5 \%$ SDS with vortexing and bath sonication. Samples were diluted to a volume of $8 \mathrm{~mL}$ with final SDS concentration of $0.2 \%$ with PBS and incubated overnight at $4{ }^{\circ} \mathrm{C}$ with $150 \mu \mathrm{L}$ high-capacity streptavidin agarose beads (Pierce). Beads were washed with SDS (1\%, $3 \times 10 \mathrm{~mL})$ and PBS $(\mathrm{pH} 7.4,3 \times 10 \mathrm{~mL})$. Proteins were eluted by boiling beads in $2 x$ SDS sample buffer (100 $\mu \mathrm{L}$, Boston Bio Products, reducing). Samples were run 1 $\mathrm{cm}$ into an SDS-PAGE gel (4-12\% Bolt Bis-tris plus, ThermoFisher Scientific), Coomassie stained for 10 
min (InstantBlue, Expedeon), and destained in water for $1 \mathrm{~h}$. Lanes were cut from the gel, washed with 1:1 acetonitrile/water $(3 \times 1 \mathrm{~mL})$, dried, and stored at $-80^{\circ} \mathrm{C}$.

In-gel protease digestion

Gel samples were reduced with a $100 \mu \mathrm{L}$ solution of TCEP $(20 \mathrm{mM})$ in aqueous triethylammonium bicarbonate (TEAB, $25 \mathrm{mM}$ ) for $45 \mathrm{~min}$ at $37^{\circ} \mathrm{C}$. The reducing solution was removed and replaced with the same volume of iodoacetamide (10 mM, Sigma) in aqueous TEAB (25 mM) for $45 \mathrm{~min}$ at room temperature. Gel samples were washed with $200 \mu \mathrm{L}$ TEAB buffer $(25 \mathrm{mM}, 10 \mathrm{~min})$ and acetonitrile. RapiGest $(0.1 \%, 20$ $\mu \mathrm{L}$ Waters) was incubated with gel pieces for $10 \mathrm{~min}$ at $37^{\circ} \mathrm{C}$. All liquid was removed and gel pieces were dried by SpeedVac. Trypsin $(0.06 \mu \mathrm{g} / 5 \mu \mathrm{L})$ in $50 \mathrm{mM}$ TEAB was added to the gel pieces and digested in a thermomixer overnight at $37^{\circ} \mathrm{C}$. Gel pieces were extracted with $20 \mathrm{mM}$ TEAB buffer, pooled, and concentrated on a SpeedVac prior to LC-MS/MS analysis.

Liquid chromatography-tandem mass spectrometry (LC-MS/MS) analysis

LC-MS/MS analysis of samples was performed on an Orbitrap Elite Hybrid Ion Trap-Orbitrap Mass Spectrometer (ThermoFisher Scientific) equipped with EASY-nLC 1000 liquid chromatography system (ThermoFisher Scientific). Peptides were separated onto a $100 \mu \mathrm{m}$ inner diameter microcapillary trapping column packed first with approximately $5 \mathrm{~cm}$ of C18 Reprosil resin $(5 \mu \mathrm{m}, 100 \AA$, Dr. Maisch $\mathrm{GmbH}$, Germany) followed by analytical column $\sim 20 \mathrm{~cm}$ of Reprosil resin $(1.8 \mu \mathrm{m}, 200 \AA$, Dr. Maisch $\mathrm{GmbH}$, Germany). Separation was achieved through applying a gradient from $5-27 \%$ ACN in $0.1 \%$ formic acid over $90 \mathrm{~min}$ at $200 \mathrm{~nL} \mathrm{~min}{ }^{-1}$. Electrospray ionization was enabled through applying a voltage of $1.8 \mathrm{kV}$ using a home-made electrode junction at the end of the microcapillary column and sprayed from fused silica pico tips (New Objective). The mass spectrometry survey scan was performed in the Orbitrap in the range of $395-1,800 \mathrm{~m} / \mathrm{z}$ at a resolution of $6 \times 10^{4}$, followed by the selection of the twenty most intense ions (TOP20) for CID-MS2 fragmentation in the lon trap using a precursor isolation width window of $2 \mathrm{~m} / \mathrm{z}$, AGC setting of 10,000, and a maximum ion accumulation of $200 \mathrm{~ms}$. Singly charged ion species were not subjected to CID fragmentation. Normalized collision energy was set to $35 \mathrm{~V}$ and an activation time of $10 \mathrm{~ms}$. Ions in a $10 \mathrm{ppm} \mathrm{m/z} \mathrm{window} \mathrm{around} \mathrm{ions} \mathrm{selected} \mathrm{for} \mathrm{MS2} \mathrm{were} \mathrm{excluded} \mathrm{from} \mathrm{further} \mathrm{selection} \mathrm{for} \mathrm{fragmentation}$ for $60 \mathrm{~s}$. The same TOP20 ions were subjected to HCD MS2 event in Orbitrap part of the instrument. The fragment ion isolation width was set to $0.7 \mathrm{~m} / \mathrm{z}$, AGC was set to 50,000 , the maximum ion time was $200 \mathrm{~ms}$, normalized collision energy was set to $27 \mathrm{~V}$ and an activation time of $1 \mathrm{~ms}$ for each HCD MS2 scan.

MS data analysis:

Raw data were submitted for analysis in Proteome Discoverer 2.3 (ThermoFisher Scientific) software. Assignment of MS/MS spectra was performed using the Sequest HT algorithm by searching the data against a protein sequence database including all entries from our Uniport_Human2016_SPonly database as well as other known contaminants such as human keratins and common lab contaminants. Sequest HT searches were performed using a $20 \mathrm{ppm}$ precursor ion tolerance and requiring each peptides $\mathrm{N}-/ \mathrm{C}$ termini to adhere with trypsin protease specificity, while allowing up to two missed cleavages. Methionine oxidation $(+15.99492 \mathrm{Da})$ was set as variable modification. A MS2 spectra assignment false discovery rate (FDR) of $1 \%$ on both protein and peptide level was achieved by applying the target-decoy database search. Protein abundance was determined from the peak areas of the three most abundant peptides per protein.

\section{Expression and purification of GPX $4^{\mathrm{U} 46 \mathrm{C}}$}

Description of GPX $4^{\mathrm{U} 46 \mathrm{C}}$ allCys(-) protein

The GPX $4^{\mathrm{U} 46 \mathrm{C}}$ allCys(-) protein we used for assessing compound binding contains only a single cysteine at position 46 (Figure S6A). While this U46C mutation reduces GPX4 enzymatic activity by more than $99 \%$, ${ }^{6}$ the thiol group in the active site remains capable of binding covalent inhibitors. ${ }^{5}$ This protein was used for binding experiments because the selenocysteine-to-cysteine mutation at position 46 enables efficient expression of in bacterial cells and replacement of the seven cysteine residues present in WT GPX4 with serine residues (Figure S6A) reduces the propensity for GPX4 aggregation ${ }^{6}$ and eliminates other potential binding sites. The GPX $4^{\mathrm{U} 46 \mathrm{C}}$ allCys(-) protein is prone to oxidation of the C46 thiol group to sulfinic acid and sulfonic acid under the assay conditions (Figure S6C), which renders this residue non-nucleophilic and prevents binding of covalent inhibitors. Similar oxidation of the C46 thiol in mutant GPX4 protein has been observed previously. ${ }^{7}$ 
Expression and purification of GPX $4^{\mathrm{U} 46 \mathrm{C}}$ allCys(-) protein

GPX $4^{\mathrm{U} 46 \mathrm{C}}$ protein was prepared as previously described. ${ }^{5}$ In this construct, the selenocysteine 46 residue (U46) was mutated to cysteine. All 7 other cysteine residues were mutated to serine to prevent reactivity at other sites. Proteins were expressed in Origami B (DE3) competent cells (EMD-Millipore). Large-scale expression of GPX4 proteins was performed by growing cultures in LB at $37^{\circ} \mathrm{C}$ with orbital shaking at 180 $\mathrm{rpm}$ to mid-log phase $\left(\mathrm{A}_{600} \sim 0.6-0.8\right)$. Cultures were then cooled to $18^{\circ} \mathrm{C}$ for 30 min before induction with $0.5 \mathrm{mM}$ isopropyl $\beta$-D-1-thiogalactopyranoside (IPTG). Induced cultures were grown for $18 \mathrm{~h}$ at $18{ }^{\circ} \mathrm{C}$. Cell pellets were harvested via centrifugation and stored at $-20^{\circ} \mathrm{C}$.

Cell pellets were lysed in Bugbuster (EMD-Millipore) and Lysonase (EMD-Millipore) by incubating for $15 \mathrm{~min}$ at room temperature. Soluble protein was extracted by centrifugation $(16,000 \mathrm{x} \mathrm{g})$ and filtered $(0.22$ $\mu \mathrm{m}$ filter) before loading onto $5 \mathrm{~mL}$ Ni-charged HisTrap columns (GE Healthcare). Running buffers for the column were as follows: Buffer A contained $20 \mathrm{mM}$ sodium phosphate $\mathrm{pH} 7.4,500 \mathrm{mM} \mathrm{NaCl}, 20 \mathrm{mM}$ imidazole, and buffer B contained the same as Buffer A but with $500 \mathrm{mM}$ imidazole. The column was washed with 3-5 column volumes of buffer $A$ and bound protein was eluted with a linear gradient from buffer $A$ to $B$.

Combined fractions were loaded directly onto a preparation grade Superdex 75 10/300 GL column (GE LifeSciences) using an isocratic elution in $25 \mathrm{mM}$ HEPES, $150 \mathrm{mM} \mathrm{NaCl}, \mathrm{pH} 7.4$, to remove low-molecular weight contaminants and exchange buffer. Eluted fractions were concentrated and the His(6)-MBP fusion was cleaved by incubation with TEV protease overnight at $4{ }^{\circ} \mathrm{C}$. The next day, digested samples were passed through a $\mathrm{Ni}^{2+}$-charged HisTrap column and flow-through were collected. Proteins were concentrated using centrifugal filters (EMD-Millipore) and stored at $-80^{\circ} \mathrm{C}$ until use.

\section{Intact protein mass spectrometry GPX4 binding assay}

Compounds in DMSO ( $1 \mu \mathrm{L}, 5 \mathrm{mM}$ DMSO solution; $50 \mu \mathrm{M}$ final concentration, $1 \% \mathrm{v} / \mathrm{v}$ final DMSO concentration) were added to a $100 \mu \mathrm{L}$ solution of GPX4 ${ }^{\mathrm{U} 46 \mathrm{C}}$ protein $(5 \mu \mathrm{M}, 0.1 \mathrm{mg} / \mathrm{mL})$ in HEPES buffer (25 mM HEPES, $150 \mathrm{mM} \mathrm{NaCl}, \mathrm{pH}$ 7.4). Reactions were incubated at ambient temperature for $1 \mathrm{~h}$. Reaction samples were immediately subjected to LCMS analysis. Covalent binding was detected using a Thermo QExactive LC-MS/MS system (ThermoFisher Scientific). Samples were loaded on a $2.1 \times 100 \mathrm{~mm}$ Agilent Zorbax 300SB C8 column and eluted with $10 \mathrm{~min}$ gradient of increasing concentrations of $0.1 \%$ formic acid in acetonitrile. LC-MS/MS data were analyzed using Thermo BioPharma Finder 3.0 (ThermoFisher Scientific).

\section{General synthetic methods}

Compounds were synthesized using standard procedures. Air- and moisture-sensitive reactions were performed in oven-dried glassware under a positive pressure of nitrogen. All reagents were obtained from commercial sources and used as received, unless otherwise noted. Anhydrous organic solvents were purchased from Sigma-Aldrich. Flash column chromatography was performed using RediSep Rf normalphase silica columns ( $60 \AA, 35-70 \mu \mathrm{m}$, Teledyne Isco) or RediSep Rf reversed-phase C18 columns (60 $\AA$, 40-63 $\mu \mathrm{m}$, Teledyne Isco) on a Combiflash Rf 150 purification system (Teledyne Isco). Low-resolution mass spectrometry (LRMS) data were obtained with a Waters 2975 LC separations module coupled to a MircoMass ZQ 200 single quadrupole detector operating in ESI+ or ESI- mode. High-resolution mass spectrometry (HRMS) data were obtained with a ThermoFisher Scientific Q Exactive HF coupled to a ThermoFisher Scientific UHPLC System. Infrared (IR) spectra were recorded on a Nicolet Avatar 370 DTGS FTIR with a Smart Orbit diamond attenuated total reflectance accessory. The thin-film method was used for IR measurements unless otherwise noted. NMR spectra were recorded on Bruker Ultrashield Advance $300\left({ }^{1} \mathrm{H}, 300 \mathrm{MHz} ;{ }^{13} \mathrm{C}, 75 \mathrm{MHz}\right)$ or Bruker Ultrashield Advance $400\left({ }^{1} \mathrm{H}, 400 \mathrm{MHz} ;{ }^{13} \mathrm{C}, 100 \mathrm{MHz}\right)$ spectrometers. NMR solvents were purchased from Cambridge Isotope Laboratories or Sigma-Aldrich. Chemical shifts are reported in parts per million ( $\mathrm{ppm}, \delta$ scale) relative to residual non-deuterated solvent as internal standard: chloroform- $d\left(\mathrm{CDCl}_{3} ; \delta_{H}=7.26 ; \delta_{C}=77.16\right)$, methanol- $d_{4}\left(\delta_{H}=3.31, \delta_{C}=49.00\right)$, dimethylsulfoxide- $d_{6}\left(\mathrm{DMSO}-d_{6} ; \delta_{H}=2.50, \delta_{\mathrm{C}}=39.52\right)$, acetonitrile- $d_{3}\left(\mathrm{MeCN}-d_{3} ; \delta_{H}=1.94, \delta_{\mathrm{C}}=1.32\right)$, acetone- $d_{6}\left(\delta_{\mathrm{H}}=2.05, \delta_{\mathrm{C}}=29.84\right)$. Data for ${ }^{1} \mathrm{H}$ NMR are reported as follows: chemical shift, multiplicity ( $\mathrm{s}$ = singlet, $\mathrm{d}=$ doublet, $\mathrm{t}=$ triplet, $\mathrm{q}=$ quartet, $\mathrm{m}=$ multiplet, $\mathrm{br}=$ broad), coupling constants $(\mathrm{J})$ in $\mathrm{Hz}$, and integration. 


$\begin{array}{cl}\text { Abbreviations } & \\ \text { AcOH } & \text { acetic acid } \\ \text { CDI } & 1,1^{\prime} \text {-carbonyldiimidazole } \\ \text { DABCO } & \text { 1,4-diazabicyclo[2.2.2]octane } \\ \text { DBU } & \text { 1,8-diazabicyclo[5.4.0]undec-7-ene } \\ \text { DCM } & \text { dichloromethane } \\ \text { DMF } & N, N \text {-dimethylformamide } \\ \text { DMSO } & \text { dimethylsulfoxide } \\ \text { ESI } & \text { electrospray ionization } \\ \text { EtOAc } & \text { ethyl acetate } \\ \text { EtOH } & \text { ethanol } \\ \text { eq. } & \text { equivalents } \\ \text { LRMS } & \text { low-resolution mass spectra } \\ \text { MeCN } & \text { acetonitrile } \\ \text { MeOH } & \text { methanol } \\ \text { NAC } & N \text {-acetyl-L-cysteine } \\ \text { NMR } & \text { nuclear magnetic resonance } \\ \text { THF } & \text { tetrahydrofuran }\end{array}$

$\mathrm{NO}_{2}$

1-(4-methoxyphenyl)-2-nitroethan-1-one (S1): CDI (3.84 g, $23.7 \mathrm{mmol}, 1.8 \mathrm{eq}$.) was added to a solution of 4-methoxybenzoic acid $(2.00 \mathrm{~g}, 13.1 \mathrm{mmol}, 1$ eq. $)$ in dry THF $(50 \mathrm{~mL})$. The reaction was stirred for $4 \mathrm{~h}$ at room temperature. Nitromethane $(2.5 \mathrm{~mL}, 46.0 \mathrm{mmol}, 3.5$ eq.) was added slowly followed by DBU (9.8 $\mathrm{mL}, 65.7 \mathrm{mmol}, 5$ eq.). The reaction was stirred for an additional $4 \mathrm{~h}$ at room temperature and then partitioned between EtOAc and $1 \mathrm{~N} \mathrm{HCl}$. The organic layer was collected, washed several times with water, dried over anhydrous sodium sulfate, and filtered. The solvent was removed under reduced pressure and the product was precipitated from DCM. Air-drying afforded the title compound as an offwhite solid $\left(1.84 \mathrm{~g}, 72 \%\right.$ yield). This product was used without further purification. ${ }^{1} \mathrm{H} \mathrm{NMR}(400 \mathrm{MHz}$, $\left.\mathrm{CDCl}_{3}\right) \delta 7.88-7.83(\mathrm{~m}, 2 \mathrm{H}), 7.02-6.97(\mathrm{~m}, 2 \mathrm{H}), 5.83(\mathrm{~s}, 2 \mathrm{H}), 3.91(\mathrm{~s}, 3 \mathrm{H}) .{ }^{13} \mathrm{C} \mathrm{NMR}\left(101 \mathrm{MHz}, \mathrm{CDCl}_{3}\right)$ $\delta$ 184.05, 130.89, 126.62, 114.70, 81.15, 55.86. IR (ATR) vmax $\left(\mathrm{cm}^{-1}\right) 1684,1606,1557,1515,1335$, 1277, 1241, 1203, 1177, 831; ESI LRMS (m/z): [M-H] calculated for $\mathrm{C}_{9} \mathrm{H}_{9} \mathrm{NO}_{4}$ 194.05; found 194.22. These data are in agreement with literature values. ${ }^{8}$<smiles></smiles>

3,4-bis(4-methoxybenzoyl)-1,2,5-oxadiazole 2-oxide (1, NSC14988): A solution of S1 (680 mg, 3.48 mmol, 1 eq.) and $p$-toluenesulfonic acid monohydrate $(662 \mathrm{mg}, 3.48 \mathrm{mmol}, 1$ eq.) in toluene $(20 \mathrm{~mL})$ was heated at reflux for $2 \mathrm{~h}$. The resulting solution was diluted with EtOAc and washed with water. The organic layer was dried over anhydrous sodium sulfate, filtered, and concentrated under reduced pressure. Purification of the crude residue by flash column chromatography afforded the title compound (107 mg, $17 \%$ yield) as a white solid. ${ }^{1} \mathrm{H}$ NMR $\left(400 \mathrm{MHz}, \mathrm{CDCl}_{3}\right) \delta 8.27-8.18(\mathrm{~m}, 2 \mathrm{H}), 7.92-7.81(\mathrm{~m}$, $2 \mathrm{H}), 7.05-6.93(\mathrm{~m}, 4 \mathrm{H}), 3.92(\mathrm{~s}, 3 \mathrm{H}), 3.90(\mathrm{~s}, 3 \mathrm{H}) .{ }^{13} \mathrm{C}$ NMR $\left(101 \mathrm{MHz}, \mathrm{CDCl}_{3}\right) \delta$ 180.07, 178.77, 165.66, 165.54, 154.93, 133.32, 132.53, 127.14, 127.03, 114.75, 114.52, 112.30, 55.87. IR (ATR) vmax 
$\left(\mathrm{cm}^{-1}\right) 1676,1655,1596,1573,1512,1467,1425,1324,1267,1171,1102,1025,925,897,844,811$, 780, 767, 612. ESI LRMS (m/z): [M+H] ${ }^{+}$calculated for $\mathrm{C}_{18} \mathrm{H}_{14} \mathrm{~N}_{2} \mathrm{O}_{6} 355.09$; found 355.14. ESI HRMS $(\mathrm{m} / \mathrm{z}):[\mathrm{M}+\mathrm{H}]^{+}$calculated for $\mathrm{C}_{18} \mathrm{H}_{14} \mathrm{~N}_{2} \mathrm{O}_{6} 355.0930$; found 355.0922 . These data are in agreement with reported values. ${ }^{9}$<smiles>Cc1ccc(C(=O)C[N+](=O)[O-])cc1</smiles>

2-nitro-1-(p-tolyl)ethan-1-one (S2): CDI (3.93 g, $24.2 \mathrm{mmol}, 1.1 \mathrm{eq}$.) was added to a solution of $p$-toluic acid $(3.00 \mathrm{~g}, 22.0 \mathrm{mmol}, 1 \mathrm{eq}$.) in dry THF $(18 \mathrm{~mL})$. The reaction was stirred for $2 \mathrm{~h}$ at room temperature. Nitromethane $(3.5 \mathrm{~mL}, 66.1 \mathrm{mmol}, 3$ eq.) was added slowly followed by DBU $(14.8 \mathrm{~mL}, 99.2 \mathrm{mmol}, 4.5$ eq.). The reaction was stirred overnight at room temperature and then partitioned between EtOAc and 1 $\mathrm{N} \mathrm{HCl}$. The organic layer was collected, washed several times with water, dried over anhydrous sodium sulfate, and filtered. The solvent was removed under reduced pressure and the product was precipitated from DCM. Air-drying afforded the title compound as an off-white solid $(3.7 \mathrm{~g}, 94 \%$ yield $)$. This product was used without further purification. ${ }^{1} \mathrm{H} \mathrm{NMR}\left(400 \mathrm{MHz}, \mathrm{CDCl}_{3}\right) \delta 7.77$ (d, $\left.J=8.0 \mathrm{~Hz}, 2 \mathrm{H}\right), 7.33(\mathrm{~d}, \mathrm{~J}=$ $7.9 \mathrm{~Hz}, 2 \mathrm{H}), 5.86(\mathrm{~s}, 2 \mathrm{H}), 2.45$ (s, 3H). ${ }^{13} \mathrm{C}$ NMR $\left(101 \mathrm{MHz}, \mathrm{CDCl}_{3}\right) \delta 185.31,146.57,131.16,130.13$, 128.50, 81.35, 22.01. IR (ATR) vmax $\left(\mathrm{cm}^{-1}\right) 3107,2960,1691,1609,1555,1408,1389,1329,1232$, 1212, 1200, 1185, 1003, 817, 735, 695, 581. ESI LRMS (m/z): [M-H] calculated for $\mathrm{C}_{9} \mathrm{H}_{9} \mathrm{NO}_{3}$ 178.05; found 178.13 . These data are in agreement with literature values. ${ }^{10}$<smiles>Cc1ccc(C(=O)c2no[n+]([O-])c2C(=O)c2ccc(C)cc2)cc1</smiles>

3,4-bis(4-methylbenzoyl)-1,2,5-oxadiazole 2-oxide (2): A solution of $\mathbf{S} 2$ (1.50 g, $8.37 \mathrm{mmol}, 1 \mathrm{eq}$.) and p-toluenesulfonic acid monohydrate $(1.59 \mathrm{~g}, 8.37 \mathrm{mmol}, 1$ eq.) in benzene $(50 \mathrm{~mL})$ was heated at reflux for $1 \mathrm{~h}$. The resulting solution was diluted with EtOAc and washed with water. The organic layer was dried over anhydrous sodium sulfate, filtered, and concentrated under reduced pressure. Recrystallization of the crude product from EtOH afforded the title compound $\left(0.72 \mathrm{~g}, 53 \%\right.$ yield) as a white solid. ${ }^{1} \mathrm{H}$ NMR $\left(300 \mathrm{MHz}, \mathrm{CDCl}_{3}\right) \delta 8.14-8.07(\mathrm{~m}, 2 \mathrm{H}), 7.79-7.72(\mathrm{~m}, 2 \mathrm{H}), 7.37-7.29(\mathrm{~m}, 4 \mathrm{H}), 2.47(\mathrm{~s}, 3 \mathrm{H}), 2.44(\mathrm{~s}$, 3H). ${ }^{13} \mathrm{C}$ NMR $\left(101 \mathrm{MHz}, \mathrm{CDCl}_{3}\right) \delta 181.29,179.95,154.53,146.95,146.73,131.49,131.45,130.70$, 129.96, 129.86, 129.83, 129.74, 111.86, 22.00, 21.96; IR (ATR) vmax $\left(\mathrm{cm}^{-1}\right)$ 1683, 1661, 1604, 1469, 1330, 1243, 1182, 1103, 924, 895, 833, 776, 755, 612, 473; ESI LRMS (m/z): [M+H] ${ }^{+}$calculated for $\mathrm{C}_{18} \mathrm{H}_{14} \mathrm{~N}_{2} \mathrm{O}_{4}$ 323.10; found 323.24. ESI HRMS (m/z): [M+H] $]^{+}$calculated for $\mathrm{C}_{18} \mathrm{H}_{14} \mathrm{~N}_{2} \mathrm{O}_{4}$ 323.1032; found 323.1025. These data are in agreement with reported values. ${ }^{9}$<smiles>O=C(C[N+](=O)[O-])c1ccccc1</smiles>

2-nitro-1-phenylethan-1-one (S3): CDI (2.19 g, $13.51 \mathrm{mmol}, 1.1 \mathrm{eq}$.) was added in portions to a solution of benzoic acid $(1.5 \mathrm{~g}, 12.28 \mathrm{mmol}, 1 \mathrm{eq}$.) in dry THF $(10 \mathrm{~mL})$. The mixture was stirred at ambient temperature for $1 \mathrm{~h}$. Nitromethane $(1.98 \mathrm{~mL}, 36.85 \mathrm{mmol}, 3$ eq. $)$ was added followed by DBU $(8.27 \mathrm{~mL}$, 55. $27 \mathrm{mmol}, 4.5$ eq.). After stirring overnight at ambient temperature, the reaction was partitioned between EtOAc and aqueous $1 \mathrm{~N} \mathrm{HCl}$. The organic layer was collected, washed several times with water, dried over anhydrous sodium sulfate, and filtered. The solvent was removed under reduced pressure and 
the product was precipitated from DCM. Air-drying afforded the title compound $(1.21 \mathrm{~g}, 60 \%$ yield) as a white solid. This product was used without further purification. ${ }^{1} \mathrm{H} \mathrm{NMR}\left(400 \mathrm{MHz}, \mathrm{CDCl}_{3}\right) \delta 7.94-7.82$ $(\mathrm{m}, 2 \mathrm{H}), 7.74-7.65(\mathrm{~m}, 1 \mathrm{H}), 7.62-7.50(\mathrm{~m}, 2 \mathrm{H}), 5.90(\mathrm{~s}, 2 \mathrm{H}) .{ }^{13} \mathrm{C} \mathrm{NMR}\left(101 \mathrm{MHz}, \mathrm{CDCl}_{3}\right) \delta 185.79$, 135.23, 133.59, 129.46, 128.39, 81.40. IR (ATR) vmax $\left(\mathrm{cm}^{-1}\right) 3019,2962,1695,1598,1583,1553,1453$, 1408, 1384, 1333, 1317, 1228, 1203, 1188, 1000, 760, 723, 686, 663, 588, 568. ESI LRMS (m/z): [M-H] calculated for $\mathrm{C}_{8} \mathrm{H}_{7} \mathrm{NO}_{3}$ 164.04; found 163.97. These data are in agreement with literature values. ${ }^{11}$<smiles>O=C(c1ccccc1)c1no[n+]([O-])c1C(=O)c1ccccc1</smiles>

3,4-dibenzoyl-1,2,5-oxadiazole 2-oxide (3): A solution of S3 (600 mg, $3.63 \mathrm{mmol}, 1$ eq.) and ptoluenesulfonic acid monohydrate $(691 \mathrm{mg}, 3.63 \mathrm{mmol}, 1$ eq.) was reluxed in benzene $(25 \mathrm{~mL})$ for $2 \mathrm{~h}$. The reaction was cooled and partitioned between EtOAc and water. The organic layer was collected, dried over anhydrous sodium sulfate, and concentrated. The title compound (199 $\mathrm{mg}, 37 \%$ yield) was obtained by recrystallization from EtOH. ${ }^{1} \mathrm{H}$ NMR $\left(400 \mathrm{MHz}, \mathrm{CDCl}_{3}\right) \delta 8.24-8.19(\mathrm{~m}, 2 \mathrm{H}), 7.90-7.84(\mathrm{~m}$, $2 \mathrm{H}), 7.75-7.66(\mathrm{~m}, 2 \mathrm{H}), 7.60-7.50(\mathrm{~m}, 4 \mathrm{H}) .{ }^{13} \mathrm{C}$ NMR $\left(101 \mathrm{MHz}, \mathrm{CDCl}_{3}\right) \delta$ 181.91, 180.56, 154.46, $135.59,135.44,134.02,134.00,130.70,129.80,129.38,129.17,129.08,111.77$. IR (ATR) vmax $\left(\mathrm{cm}^{-1}\right)$ $3065,1770,1685,1664,1610,1597,1581,1470,1451,1329,1238,1219,1180,1103,1033,1000,923$, 894, 794, 726, 685, 667. ESI LRMS (m/z): [M-H] calculated for $\mathrm{C}_{16} \mathrm{H}_{10} \mathrm{~N}_{2} \mathrm{O}_{4}$ 293.06; found 293.23. ESI HRMS (m/z): $[\mathrm{M}+\mathrm{H}]^{+}$calculated for $\mathrm{C}_{16} \mathrm{H}_{10} \mathrm{~N}_{2} \mathrm{O}_{4}$ 295.0719; found 295.0712. These data are in good agreement with literature values. ${ }^{9,12}$<smiles>O=C(c1ccc(CBr)cc1)c1no[n+]([O-])c1C(=O)c1ccc(CBr)cc1</smiles>

3,4-bis(4-(bromomethyl)benzoyl)-1,2,5-oxadiazole 2-oxide (S4): A solution of 2 (166 mg, $0.52 \mathrm{mmol}, 1$ eq.) was dissolved in dry MeCN (3 mL). NBS (275 mg, $1.55 \mathrm{mmol}, 3$ eq.) and AIBN (8 mg, $0.05 \mathrm{mmol}, 0.1$ eq.) were added in succession and the reaction was stirred at reflux for $24 \mathrm{~h}$. After cooling, the resulting precipitate was removed by filtration. The filtrate was concentrated and the resulting crude residue purified by flash column chromatography (EtOAc/hexanes gradient) to afford the title compound (40 mg, $16 \%$ yield) as a white solid. ${ }^{1} \mathrm{H}$ NMR $\left(400 \mathrm{MHz}, \mathrm{CDCl}_{3}\right) \delta 8.21-8.16(\mathrm{~m}, 2 \mathrm{H}), 7.86-7.81(\mathrm{~m}, 2 \mathrm{H}), 7.61-$ $7.53(\mathrm{~m}, 4 \mathrm{H}), 4.53(\mathrm{~s}, 2 \mathrm{H}), 4.50(\mathrm{~s}, 2 \mathrm{H}) .{ }^{13} \mathrm{C} \mathrm{NMR}\left(101 \mathrm{MHz}, \mathrm{CDCl}_{3}\right) \delta 181.12,179.77,154.29,145.53$, $145.39,133.62,133.58,131.20,130.29,130.02,129.79,111.62,31.73,31.67$.<smiles>NCc1ccc(C(=O)c2no[n+]([O-])c2C(=O)c2ccc(CN)cc2)cc1</smiles>

3,4-bis(4-(azidomethyl)benzoyl)-1,2,5-oxadiazole 2-oxide (4): A solution of S5 (30 mg, $0.06 \mathrm{mmol}, 1$ eq.) was dissolved in 2:1 DMSO/acetic acid $(150 \mu \mathrm{L})$. Sodium azide $(9 \mathrm{mg}, 0.13 \mathrm{mmol}, 2.1 \mathrm{eq}$.) was added and the reaction was stirred for $15 \mathrm{~m}$ at ambient temperature. The mixture was partitioned between EtOAc and water. The organic fraction was collected and washed with water and brine, dried over anhydrous sodium sulfate, filtered, and concentrated under reduced pressure. Purification of the crude residue by flash column chromatography (EtOAc/hexanes gradient) afforded the title compound (18 $\mathrm{mg}, 72 \%$ yield) as a white solid. ${ }^{1} \mathrm{H} \mathrm{NMR}\left(400 \mathrm{MHz}, \mathrm{CDCl}_{3}\right) \delta 8.23(\mathrm{~d}, J=8.0 \mathrm{~Hz}, 2 \mathrm{H}), 7.88(\mathrm{~d}, J=7.9 \mathrm{~Hz}$, 
$2 \mathrm{H}), 7.50$ (dd, $J=13.2,8.0 \mathrm{~Hz}, 4 \mathrm{H}), 4.49(\mathrm{~s}, 2 \mathrm{H}), 4.48(\mathrm{~s}, 2 \mathrm{H}) .{ }^{13} \mathrm{C} \mathrm{NMR}\left(101 \mathrm{MHz}, \mathrm{CDCl}_{3}\right) \delta 181.26$, 179.92, 154.30, 143.60, 143.38, 133.65, 133.63, 131.23, 130.31, 128.64, 128.48, 111.62, 77.36, 54.27, 54.25. $\mathrm{HRMS}(\mathrm{m} / \mathrm{z})$ : $[\mathrm{M}+\mathrm{H}]^{+}$calculated for $\mathrm{C}_{18} \mathrm{H}_{12} \mathrm{~N}_{8} \mathrm{O}_{4} 405.1054$; found 405.1055.<smiles>COC(=O)c1ccc(C(=O)C[N+](=O)[O-])cc1</smiles>

methyl 4-(2-nitroacetyl)benzoate (S5): CDI (990 mg, $6.11 \mathrm{mmol}, 1.1 \mathrm{eq}$.) was added to a solution of 4(methoxycarbonyl)benzoic acid $(1.0 \mathrm{~g}, 5.55 \mathrm{mmol}, 1 \mathrm{eq}$.) in dry THF $(9 \mathrm{~mL})$. The reaction was stirred for 2 $\mathrm{h}$ at room temperature. Nitromethane $(0.89 \mathrm{~mL}, 16.6 \mathrm{mmol}, 3$ eq.) was added slowly followed by DBU (3.7 $\mathrm{mL}, 25.0 \mathrm{mmol}, 4.5$ eq.). The reaction was stirred overnight at room temperature and then partitioned between EtOAc and $1 \mathrm{~N} \mathrm{HCl}$. The organic layer was collected, washed several times with water, dried over anhydrous sodium sulfate, and filtered. The solvent was removed under reduced pressure and the product was precipitated from DCM. Air-drying afforded the title compound as an off-white solid $(1.17 \mathrm{~g}$, $95 \%$ yield). This product was used without further purification. ${ }^{1} \mathrm{H}$ NMR $\left(400 \mathrm{MHz}\right.$, DMSO- $\left.d_{6}\right) \delta 8.16-$ $8.11(\mathrm{~m}, 2 \mathrm{H}), 8.10-8.04(\mathrm{~m}, 2 \mathrm{H}), 6.59(\mathrm{~s}, 2 \mathrm{H}), 3.90(\mathrm{~s}, 3 \mathrm{H}) .{ }^{13} \mathrm{C}$ NMR $\left(101 \mathrm{MHz}, \mathrm{DMSO}-\mathrm{d}_{6}\right) \delta 188.24$, 165.34, 136.75, 134.49, 129.63, 128.79, 82.92, 52.67, 39.99. ESI LRMS (m/z): [M-H] calculated for $\mathrm{C}_{10} \mathrm{H}_{9} \mathrm{NO}_{5}$ 222.04; found 222.07. ESI HRMS (m/z): [M-H] ${ }^{-}$calculated for $\mathrm{C}_{10} \mathrm{H}_{9} \mathrm{NO}_{5}$ 222.0403; found 222.0408. These data are in agreement with reported values. ${ }^{11}$<smiles>O=C(O)c1ccc(C(=O)C[N+](=O)[O-])cc1</smiles>

4-(2-nitroacetyl)benzoic acid (S6): Aqueous sodium hydroxide solution ( $5 \mathrm{~N}, 6.3 \mathrm{~mL}, 31.48 \mathrm{mmol}, 6$ eq.) was added to a suspension of $\mathbf{S 5}(1.17 \mathrm{~g}, 5.25 \mathrm{mmol}, 1 \mathrm{eq}$.) in THF $(50 \mathrm{~mL})$ and water $(15 \mathrm{~mL})$. The reaction was stirred at ambient temperature for 30 minutes, acidified by addition of aqueous $1 \mathrm{~N} \mathrm{HCl}$, and extracted with EtOAc. The combined organic layers were dried over anhydrous sodium sulfate, filtered, and concentrated to afford the title compound $(886 \mathrm{mg}, 81 \%$ yield) as a white solid. This product was used without further purification. ${ }^{1} \mathrm{H}$ NMR $\left(400 \mathrm{MHz}\right.$, DMSO- $\left.d_{6}\right) \delta 13.43(\mathrm{~s}, 1 \mathrm{H}), 8.13-8.09(\mathrm{~m}, 2 \mathrm{H}), 8.06$ $-8.03(\mathrm{~m}, 2 \mathrm{H}), 6.59(\mathrm{~s}, 2 \mathrm{H})$. ESI LRMS (m/z): [M-H] calculated for $\mathrm{C}_{9} \mathrm{H}_{7} \mathrm{NO}_{5}$ 208.02; found 208.04 .<smiles>O=C(O)c1ccc(C(=O)c2no[n+]([O-])c2C(=O)c2ccc(C(=O)O)cc2)cc1</smiles>

3,4-bis(4-carboxybenzoyl)-1,2,5-oxadiazole 2-oxide (16): A solution of $\mathbf{S 6}$ (2.90 g, $13.87 \mathrm{mmol}, 1$ eq.) and $p$-toluenesulfonic acid monohydrate $(2.64 \mathrm{~g}, 13.87 \mathrm{mmol}, 1$ eq.) was refluxed in $m$-xylene $(15 \mathrm{~mL})$ for $1 \mathrm{~h}$. The solution was concentrated under reduced pressure. Purification of the crude product was accomplished by reversed-phase purification using a mobile phase of water and acetonitrile supplemented with $0.1 \%$ formic acid. After lyophilization, the title compound ( $890 \mathrm{mg}, 34 \%$ yield) was obtained as a white solid. ${ }^{1} \mathrm{H}$ NMR $\left(400 \mathrm{MHz}\right.$, DMSO- $\left.d_{6}\right) \delta 13.42(\mathrm{~s}, 2 \mathrm{H}), 8.28-8.21(\mathrm{~m}, 1 \mathrm{H}), 8.18-8.00$ $(\mathrm{m}, 5 \mathrm{H}) .{ }^{13} \mathrm{C}$ NMR $\left(101 \mathrm{MHz}\right.$, DMSO- $\left.d_{6}\right) \delta 182.61,181.07,180.35,167.12,166.78,166.72,137.44$, $137.30,136.74,136.70,134.90,130.87,130.24,130.14,129.92,112.95$. ESI LRMS (m/z): [M-H] 
calculated for $\mathrm{C}_{18} \mathrm{H}_{10} \mathrm{~N}_{2} \mathrm{O}_{8} 381.04$; found 381.18. ESI HRMS (m/z): [M-H]' calculated for $\mathrm{C}_{18} \mathrm{H}_{10} \mathrm{~N}_{2} \mathrm{O}_{8}$ 381.0359; found 381.0368 .<smiles>C#CCOC(=O)c1ccc(C(=O)c2no[n+]([O-])c2C(=O)c2ccc(C(=O)OCC#C)cc2)cc1</smiles>

3,4-bis(4-((prop-2-yn-1-yloxy)carbonyl)benzoyl)-1,2,5-oxadiazole 2-oxide (5): A solution of 16 (75 mg, $0.02 \mathrm{mmol}$, 1 eq.) in thionyl chloride $(2 \mathrm{~mL})$ and toluene $(2 \mathrm{~mL})$ was heated at $60^{\circ} \mathrm{C}$ for $3 \mathrm{~h}$. The solvent was removed under reduced pressure and the crude residue dissolved in dry THF $(2 \mathrm{~mL})$. Propargyl alcohol (566 $\mu \mathrm{L}, 9.81 \mathrm{mmol}, 50$ eq.) was added and the reaction was stirred at $60^{\circ} \mathrm{C}$ for $1 \mathrm{~h}$. The solvent was removed under reduced pressure. Purification of the crude residue by flash column chromatography afforded the title compound (14 mg, $15 \%$ yield) as a white solid. ${ }^{1} \mathrm{H} \mathrm{NMR}\left(400 \mathrm{MHz}, \mathrm{CDCl}_{3}\right) \delta 8.32-8.16$ (m, 6H), $7.99-7.82(\mathrm{~m}, 2 \mathrm{H}), 4.97(\mathrm{dd}, J=6.3,2.5 \mathrm{~Hz}, 4 \mathrm{H}), 2.56(\mathrm{dt}, J=3.9,2.4 \mathrm{~Hz}, 2 \mathrm{H}) .{ }^{13} \mathrm{C}$ NMR $(101$ $\left.\mathrm{MHz}, \mathrm{CDCl}_{3}\right) \delta 181.22,179.87,164.50,164.37,153.78,137.09,137.02,135.13,135.02,130.54,130.50$, 130.30, 129.49, 111.07, 77.13, 77.10, 75.58, 53.14. HRMS (m/z): $[\mathrm{M}+\mathrm{H}]^{+}$calculated for $\mathrm{C}_{24} \mathrm{H}_{14} \mathrm{~N}_{2} \mathrm{O}_{8}$ 459.0823; found 459.0836 .<smiles>Cc1ccc(C(=O)/C(=N/O)C(=NO)Sc2ccccc2)cc1</smiles>

2-(4-methylbenzoyl)-2-hydroxyiminoacetonitrile oxide (5): An aqueous solution of $1 \mathrm{~N} \mathrm{NaOH}(0.31 \mathrm{~mL}$, 2 eq.) was added to a mixture of $2(50 \mathrm{mg}, 0.16 \mathrm{mmol}, 1$ eq.) in THF $(0.7 \mathrm{~mL})$. Thiophenol $(19 \mu \mathrm{L} 0.19$ mmol, 1.2 eq.) was added immediately after. The mixture was stirred at room temperature for 15 minutes and then partitioned between EtOAc and $1 \mathrm{~N} \mathrm{HCl}$. The organic layer was collected, washed with water, brine, and dried over anhydrous $\mathrm{Na}_{2} \mathrm{SO}_{4}$. The mixture was filtered and concentrated under vacuum. Purification by flash column chromatography (0-50\% EtOAc/hexanes) afforded the title compound (19 $\mathrm{mg}, 39 \%$ yield) as a white solid. ${ }^{1} \mathrm{H}$ NMR $\left(300 \mathrm{MHz}, \mathrm{MeCN}-d_{3}\right) \delta 10.34(\mathrm{~s}, 1 \mathrm{H}), 9.76(\mathrm{~s}, 1 \mathrm{H}), 7.50-7.44$ $(\mathrm{m}, 2 \mathrm{H}), 7.41-7.32(\mathrm{~m}, 1 \mathrm{H}), 7.30-7.21(\mathrm{~m}, 2 \mathrm{H}), 7.19-7.07(\mathrm{~m}, 4 \mathrm{H}), 2.33(\mathrm{~s}, 3 \mathrm{H}) .{ }^{1} \mathrm{H}$ NMR $(300 \mathrm{MHz}$, Methanol- $\left.d_{4}\right) \delta 7.55-7.42(\mathrm{~m}, 2 \mathrm{H}), 7.38-7.28(\mathrm{~m}, 1 \mathrm{H}), 7.27-7.19(\mathrm{~m}, 4 \mathrm{H}), 7.09-7.03(\mathrm{~m}, 2 \mathrm{H}), 2.32$ (s, 3H). ${ }^{13} \mathrm{C}$ NMR $\left(101 \mathrm{MHz}, \mathrm{MeCN}-d_{3}\right) \delta 189.42,150.03,147.05,144.76,137.00,134.36,131.20$, 130.91, 130.15, 129.40, 128.45, 21.59. IR (ATR) vmax $\left(\mathrm{cm}^{-1}\right) 3629,3026,2854,1644,1605,1474,1441$, 1411, 1320, 1307, 1199, 1180, 1060, 1009, 999, 969, 856, 833, 787, 750, 691, 622, 475. ESI LRMS $(\mathrm{m} / \mathrm{z})$ : $[\mathrm{M}+\mathrm{H}]^{+}$calculated for $\mathrm{C}_{16} \mathrm{H}_{14} \mathrm{~N}_{2} \mathrm{O}_{3} \mathrm{~S} 315.08$; found 315.17. ESI HRMS (m/z): $[\mathrm{M}+\mathrm{H}]^{+}$calculated for $\mathrm{C}_{16} \mathrm{H}_{14} \mathrm{~N}_{2} \mathrm{O}_{3} \mathrm{~S}$ 315.0803; found 315.0797<smiles>CC(=O)N[C@@H](CS/C(=N\O)C(=NO)C(=O)c1ccc(C)cc1)C(=O)O</smiles>

N-acetyl-S-((1E,2Z)-1,2-bis(hydroxyimino)-3-oxo-3-(p-tolyl)propyl)-L-cysteine (6): A solution of 2 (100 mg, $0.31 \mathrm{mmol}, 1$ eq.) in 1:1 MeOH/THF $(2 \mathrm{~mL})$ was cooled to $0{ }^{\circ} \mathrm{C}$. A solution of NAC (101 mg, $0.62 \mathrm{mmol}, 2$ eq.) in aqueous $1 \mathrm{~N} \mathrm{NaOH}(1.2 \mathrm{~mL})$ was added and the mixture was stirred for $15 \mathrm{~min}$. The 
mixture was stirred at room temperature for 15 minutes and then partitioned between EtOAc and $1 \mathrm{~N} \mathrm{HCl}$. The organic layer was collected, washed with water, brine, and dried over anhydrous $\mathrm{Na}_{2} \mathrm{SO}_{4}$. Purification by flash column chromatography $(0-20 \% \mathrm{MeOH} / \mathrm{DCM})$ afforded the title compound $(70 \mathrm{mg}, 31 \%$ yield) as a white solid. ${ }^{1} \mathrm{H}$ NMR $\left(400 \mathrm{MHz}\right.$, Acetone- $\left.d_{6}\right) \delta 12.12(\mathrm{~s}, 1 \mathrm{H}), 11.04(\mathrm{~s}, 1 \mathrm{H}), 7.97-7.88(\mathrm{~m}, 2 \mathrm{H}), 7.52(\mathrm{~d}$, $J=7.8 \mathrm{~Hz}, 1 \mathrm{H}), 7.39-7.29(\mathrm{~m}, 2 \mathrm{H}), 4.76-4.64(\mathrm{~m}, 1 \mathrm{H}), 3.31(\mathrm{dd}, J=12.9,4.6 \mathrm{~Hz}, 1 \mathrm{H}), 3.17(\mathrm{dd}, J=$ 12.9, $8.0 \mathrm{~Hz}, 1 \mathrm{H}), 2.42(\mathrm{~s}, 3 \mathrm{H}), 1.98-1.96(\mathrm{~m}, 3 \mathrm{H}) .{ }^{13} \mathrm{C}$ NMR (101 MHz, Acetone-d6) $\delta$ 189.84, 171.67, $170.70,149.36,146.90,145.21,134.51,131.48,129.78,52.98,32.65,22.65,21.61$. IR (ATR) vmax (cm ${ }^{-}$ 1) $3154,2997,2848,1721,1639,1602,1541,1417,1376,1320,1307,1180,972,865,834,787,760$, 648, 623. ESI LRMS (m/z): [M+H] $]^{+}$calculated for $\mathrm{C}_{15} \mathrm{H}_{17} \mathrm{~N}_{3} \mathrm{O}_{6} \mathrm{~S} 368.09$; found 368.23. ESI HRMS (m/z): $[\mathrm{M}+\mathrm{H}]^{+}$calculated for $\mathrm{C}_{15} \mathrm{H}_{17} \mathrm{~N}_{3} \mathrm{O}_{6} \mathrm{~S} 368.0916$; found 368.0908 .<smiles>Cc1ccc(C(=O)/C(C#[N+][O-])=N/O)cc1</smiles>

a-hydroxyimino-(4-methylbenzoyl)acetonitrile oxide (11): An aqueous solution of $1 \mathrm{~N} \mathrm{NaOH}(1.2 \mathrm{~mL}$, 2 eq.) was added to a mixture of $2(200 \mathrm{mg}, 0.62 \mathrm{mmol}, 1$ eq. $)$ in THF $(2 \mathrm{~mL})$. The mixture was stirred at room temperature for 10 minutes and then partitioned between EtOAc and aqueous $1 \mathrm{~N} \mathrm{HCl}$. The organic layer was collected, washed with water and brine, and dried over anhydrous $\mathrm{Na}_{2} \mathrm{SO}_{4}$. The mixture was filtered and concentrated under vacuum. Purification by flash column chromatography $(0-20 \%$ EtOAc/hexanes) afforded the title compound ( $48 \mathrm{mg}, 37 \%$ yield) as a white solid. ${ }^{1} \mathrm{H}$ NMR $(400 \mathrm{MHz}$, Chloroform-d) $\delta 9.02(\mathrm{~s}, 1 \mathrm{H}), 7.90(\mathrm{~d}, J=8.2 \mathrm{~Hz}, 2 \mathrm{H}), 7.28(\mathrm{~d}, J=8.1 \mathrm{~Hz}, 2 \mathrm{H}), 2.44(\mathrm{~s}, 3 \mathrm{H}) .{ }^{1} \mathrm{H}$ NMR $(400$ $\left.\mathrm{MHz}, \mathrm{DMSO}-d_{6}\right) \delta 14.50(\mathrm{~s}, 1 \mathrm{H}), 7.84(\mathrm{~d}, J=7.9 \mathrm{~Hz}, 2 \mathrm{H}), 7.35(\mathrm{~d}, J=7.9 \mathrm{~Hz}, 2 \mathrm{H}), 2.39(\mathrm{~s}, 3 \mathrm{H}) .{ }^{13} \mathrm{C}$ NMR (101 MHz, Chloroform-d) $\delta 184.29,145.57,134.95,131.93,130.83,129.40,21.96$. IR (ATR) vmax $\left(\mathrm{cm}^{-1}\right)$ 3284, 2959, 2809, 2287, 1681, 1632, 1598, 1561, 1409, 1382, 1312, 1289, 1192, 1113, 1027, 873, 833, $802,787,745,727,690,642,623,543,519,466$. The strong IR peak at $2287 \mathrm{~cm}^{-1}$ is in good agreement with characteristic nitrile oxide absorbance reported values for related compounds. ${ }^{13-15}$ See Figure S13 for IR spectrum. ESI LRMS (m/z): [M+H] $]^{+}$calculated for $\mathrm{C}_{10} \mathrm{H}_{9} \mathrm{~N}_{2} \mathrm{O}_{3}$ 205.06; found 205.24.

In addition to nitrile oxide 7 , nearly one equivalent of $p$-toluic acid could be recovered from this hydrolysis reaction of 2 . The identity of isolated $p$-toluic acid was confirmed by ${ }^{1} \mathrm{H}$ NMR and LRMS data, which are in agreement with literature values ${ }^{16}$ and match those of a reference standard. ${ }^{1} \mathrm{H}$ NMR (300 MHz, DMSO-d $\left.d_{6}\right) 12.78(\mathrm{~s}, 1 \mathrm{H}), 7.91-7.76(\mathrm{~m}, 2 \mathrm{H}), 7.37-7.22(\mathrm{~m}, 2 \mathrm{H}), 2.37(\mathrm{~s}, 3 \mathrm{H})$. ESI LRMS (m/z): $[\mathrm{M}-\mathrm{H}]^{-}$calculated for $\mathrm{C}_{8} \mathrm{H}_{8} \mathrm{O}_{2}$ 135.05; found 135.09 .<smiles>Cc1ccc(C(O)c2no[n+]([O-])c2C(O)c2ccc(C)cc2)cc1</smiles>

3,4-bis(hydroxy(p-tolyl)methyl)-1,2,5-oxadiazole 2-oxide (9): A solution of 2 (50 mg, $0.16 \mathrm{mmol}, 1$ eq.) in $1: 1 \mathrm{MeOH} / \mathrm{THF}(1 \mathrm{~mL})$ was cooled to $0{ }^{\circ} \mathrm{C}$. Sodium borohydride $(12 \mathrm{mg}, 0.31 \mathrm{mmol}, 2 \mathrm{eq}$.) was added in one portion. The reaction was stirred at $0{ }^{\circ} \mathrm{C}$ for $1 \mathrm{~h}$ and subsequently quenched by addition of saturated aqueous ammonium chloride. The mixture was extracted with EtOAc and the combined organic layers were dried over anhydrous $\mathrm{Na}_{2} \mathrm{SO}_{4}$, filtered, and concentrated. Purification by flash column chromatography (EtOAc/hexanes) afforded the product $(24 \mathrm{mg}, 48 \%$ yield) as a mixture of diastereomers. ${ }^{1} \mathrm{H}$ NMR $\left(300 \mathrm{MHz}, \mathrm{CDCl}_{3}\right) \delta 7.24-7.07(\mathrm{~m}, 5 \mathrm{H}), 7.03-6.79(\mathrm{~m}, 3 \mathrm{H}), 6.07-5.62(\mathrm{~m}, 2 \mathrm{H}), 4.31-3.46$ (m, 2H), $2.39-2.25(\mathrm{~m}, 6 \mathrm{H})$. IR (ATR) vmax $\left(\mathrm{cm}^{-1}\right) 3358,3028,2923,1597,1512,1494,1451,1264$, 1195, 1180, 1110, 1067, 1005, 855, 777, 737, 654, 571, 500. ESI LRMS (m/z): [M-H] calculated for $\mathrm{C}_{18} \mathrm{H}_{18} \mathrm{~N}_{2} \mathrm{O}_{4} 325.12$; found 325.21. 
<smiles>[O-][n+]1onc(/C(=N/O)c2ccccc2)c1/C(=N/O)c1ccccc1</smiles>

3,4-bis((hydroxyimino)(phenyl)methyl)-1,2,5-oxadiazole 2-oxide (10): A solution of 3 (150 mg, 0.51 $\mathrm{mmol}, 1$ eq.) was suspended in glacial $\mathrm{AcOH}(3 \mathrm{~mL})$. A solution of hydroxylamine hydrochloride (106 $\mathrm{mg}$, $1.53 \mathrm{mmol}, 3$ eq.) in water $(1 \mathrm{~mL})$ was added. The mixture was refluxed overnight. After cooling, the mixture was extracted with EtOAc. The combined organic layers were washed with water and brine, dried over anhydrous sodium sulfate, and concentrated. Purification by flash column chromatography $(0-30 \%$ EtOAc/hexanes) afforded the title compound $\left(51 \mathrm{mg}, 31 \%\right.$ yield) as a mixture of isomers. ${ }^{1} \mathrm{H}$ NMR $(400$ $\left.\mathrm{MHz}, \mathrm{DMSO}-d_{6}\right) \delta 12.49(\mathrm{~m}, 2 \mathrm{H}), 7.68-7.33(\mathrm{~m}, 10 \mathrm{H})$. IR (ATR) vmax $\left(\mathrm{cm}^{-1}\right) 3340,1605,1446,1357$, 995, 940, 921, 823, 735, 692. ESI LRMS (m/z): $[\mathrm{M}+\mathrm{H}]^{+}$calculated for $\mathrm{C}_{16} \mathrm{H}_{12} \mathrm{~N}_{4} \mathrm{O}_{4}$ 325.09; found 325.14. ESI HRMS (m/z): $[\mathrm{M}+\mathrm{H}]^{+}$calculated for $\mathrm{C}_{16} \mathrm{H}_{12} \mathrm{~N}_{4} \mathrm{O}_{4} 325.0937$; found 325.0933 .<smiles>[O-][n+]1onc2c(-c3ccccc3)nnc(-c3ccccc3)c21</smiles>

4,7-diphenyl-[1,2,5]oxadiazolo[3,4-d]pyridazine 1-oxide (11): A solution of 3 (150 mg, $0.51 \mathrm{mmol}, 1$ eq.) was suspended in glacial $\mathrm{AcOH}(1.5 \mathrm{~mL})$. A $55 \%$ solution of hydrazine hydrate $(32 \mu \mathrm{L}, 1.02 \mathrm{mmol}, 2$ eq.) was added. The mixture was stirred at ambient temperature for $24 \mathrm{~h}$. The reaction was partitioned between EtOAc and water. The organic layer was separated and washed several times with water and brine. The organic layer was dried over anhydrous sodium sulfate, filtered, and concentrated. Purification by flash column chromatography (0-15\% EtOAc/hexanes) afforded the title compound (51 $\mathrm{mg}, 34 \%$ yield) as an orange solid. ${ }^{1} \mathrm{H}$ NMR $\left(300 \mathrm{MHz}, \mathrm{CDCl}_{3}\right) \delta 8.71-8.60(\mathrm{~m}, 2 \mathrm{H}), 8.05-7.88(\mathrm{~m}, 2 \mathrm{H}), 7.71-7.52(\mathrm{~m}$, $6 \mathrm{H}) .{ }^{13} \mathrm{C}$ NMR $\left(101 \mathrm{MHz}, \mathrm{CDCl}_{3}\right) \delta 150.51,148.43,145.24,132.75,132.06,131.93,130.50,129.71$, 129.40, 129.31, 128.85, 106.98. IR (ATR) vmax $\left(\mathrm{cm}^{-1}\right) 3051,2157,1608,1451,1433,1406,1351,1023$, 999, 946, 910, 764, 735, 689, 665, 654, 627, 610. ESI LRMS (m/z): $[\mathrm{M}+\mathrm{H}]^{+}$calculated for $\mathrm{C}_{16} \mathrm{H}_{10} \mathrm{~N}_{4} \mathrm{O}_{2}$ 291.09; found 290.96. ESI HRMS (m/z): $[\mathrm{M}+\mathrm{H}]^{+}$calculated for $\mathrm{C}_{16} \mathrm{H}_{10} \mathrm{~N}_{4} \mathrm{O}_{2}$ 291.0882; found 291.0876. IR data are consistent with previously reported values. ${ }^{17}$<smiles>ON=C(Cl)c1ccccc1</smiles>

$\mathbf{N}$-hydroxybenzimidoyl chloride (S7): NCS (551 mg, $4.13 \mathrm{mmol}, 1$ eq.) was added in small portions to a solution of benzaldehyde oxime (500 $\mathrm{mg}, 4.13 \mathrm{mmol}, 1 \mathrm{eq}$.) in dry DMF (2 mL). The reaction was stirred overnight at room temperature and subsequently partitioned between EtOAc and water. The organic layer was collected and concentrated. Purification by flash column chromatography (EtOAc/hexanes) afforded the title compound (526 mg, $82 \%$ yield) as a white solid. ${ }^{1} \mathrm{H} \mathrm{NMR}\left(400 \mathrm{MHz}, \mathrm{CDCl}_{3}\right) \delta 8.71(\mathrm{~s}, 1 \mathrm{H}), 7.90-$ $7.77(\mathrm{~m}, 2 \mathrm{H}), 7.50-7.38(\mathrm{~m}, 3 \mathrm{H}) .{ }^{13} \mathrm{C} \mathrm{NMR}\left(101 \mathrm{MHz}, \mathrm{CDCl}_{3}\right) \delta 140.67,132.47,131.16,130.94,128.68$, 127.34. IR (ATR) vmax $\left(\mathrm{cm}^{-1}\right)$ 3278, 2059, 2852, 2360, 2341, 1603, 1578, 1493, 1446, 1336, 1313, 1232 , $1182,984,932,759,686,667,615,589$. The title compound was unable to be detected by ESI-MS. The ${ }^{1} \mathrm{H}$ NMR are in agreement with previously reported values. ${ }^{18}$ 
<smiles>[O-][n+]1onc(-c2ccccc2)c1-c1ccccc1</smiles>

3,4-diphenyl-1,2,5-oxadiazole 2-oxide (12): A solution of $\mathbf{S 4}$ (250 mg, $1.61 \mathrm{mmol}, 1$ eq.) was dissolved in diethyl ether $(10 \mathrm{~mL})$. Saturated aqueous sodium carbonate solution $(5 \mathrm{~mL})$ was added and the reaction was stirred overnight at room temperature. The organic layer was separated and concentrated. Purification by flash column chromatography (EtOAc/hexanes) afforded the title compound (99 mg, 52\% yield) as a white solid. ${ }^{1} \mathrm{H}$ NMR $\left(400 \mathrm{MHz}, \mathrm{CDCl}_{3}\right) \delta 7.55-7.41(\mathrm{~m}, 10 \mathrm{H}) \cdot{ }^{13} \mathrm{C} \mathrm{NMR}\left(101 \mathrm{MHz}, \mathrm{CDCl}_{3}\right) \delta$ 156.38, 131.14, 130.70, 129.18, 129.11, 128.86, 128.46, 126.86, 123.08. IR (ATR) vmax $\left(\mathrm{cm}^{-1}\right) 3063$, $1590,1574,1505,1474,1458,1442,1420,1327,1310,1286,1173,1114,1075,1002,989,961,922$, $828,770,728,713,692,654,541,503$. These data are in agreement with previously reported values. ${ }^{19}$ The title compound was unable to be detected by ESI-MS.<smiles>O=S(=O)(c1ccccc1)c1no[n+]([O-])c1S(=O)(=O)c1ccccc1</smiles>

3,4-bis(phenylsulfonyl)-1,2,5-oxadiazole 2-oxide (13): A solution of ((nitromethyl)sulfonyl)benzene (Matrix Scientific, $250 \mathrm{mg}, 1.24 \mathrm{mmol}, 1$ eq.) and $p$-toluenesulfonic acid monohydrate was heated to reflux in $m$-xylene $(400 \mu \mathrm{L})$ for $1 \mathrm{~h}$. The mixture cooled to room temperature, diluted with $\mathrm{DCM}$, and washed with water. The organic layer was dried over anhydrous sodium sulfate, filtered, and concentrated. Purification by flash column chromatography (EtOAc/hexanes) followed by recrystallization from EtOH afforded the title compound $(48.7 \mathrm{mg}, 21 \%) .{ }^{1} \mathrm{H}$ NMR $\left(400 \mathrm{MHz}, \mathrm{CDCl}_{3}\right) \delta 8.25-8.09(\mathrm{~m}, 4 \mathrm{H})$, $7.86-7.73(\mathrm{~m}, 2 \mathrm{H}), 7.72-7.60(\mathrm{~m}, 4 \mathrm{H}) .{ }^{13} \mathrm{C} \mathrm{NMR}\left(101 \mathrm{MHz}, \mathrm{CDCl}_{3}\right) \delta$ 155.73, 137.27, 136.36, 136.33, 135.99, 130.31, 129.97, 129.70, 129.32, 115.29. IR (ATR) vmax $\left(\mathrm{cm}^{-1}\right)$ 1620, 1449, 1355, 1170, 1086 , 757, 683, 617, 581, 560. ESI LRMS (m/z): $\left[\mathrm{M}+\mathrm{H}_{2} \mathrm{O}\right]^{+}$calculated for $\mathrm{C}_{14} \mathrm{H}_{10} \mathrm{~N}_{2} \mathrm{O}_{6} \mathrm{~S}_{2}$ 384.01; found 384.11. ESI HRMS (m/z): [M+Na] ${ }^{+}$calculated for $\mathrm{C}_{14} \mathrm{H}_{10} \mathrm{~N}_{2} \mathrm{O}_{6} \mathrm{~S}_{2}$ 388.9878; found 388.9868. These data are consistent with reported values. ${ }^{20}$<smiles>CC(=O)OCc1ccc(C(=O)O)cc1</smiles>

4-(acetoxymethyl)benzoic acid (S8): A suspension of 4-(bromomethyl)benzoic acid $(2.50 \mathrm{~g}, 11.63$ mmol, 1 eq.) and sodium acetate $(2.86 \mathrm{~g}, 34.88 \mathrm{mmol}, 3$ eq.) in acetic acid $(25 \mathrm{~mL})$ was refluxed for $24 \mathrm{~h}$. The resulting solution was cooled, poured onto ice, and extracted with EtOAc. The combined organic layers were washed with aqueous $0.1 \mathrm{~N} \mathrm{HCl}$ and dried over anhydrous sodium sulfate. Removal of the solvent under reduced pressure afforded the title compound $(2.1 \mathrm{~g}, 93 \%$ yield $)$ as a white solid. This product was used without further purification. ${ }^{1} \mathrm{H}$ NMR $\left(400 \mathrm{MHz}, \mathrm{CDCl}_{3}\right) \delta 8.12(\mathrm{~d}, \mathrm{~J}=8.1 \mathrm{~Hz}, 2 \mathrm{H}), 7.46$ $(\mathrm{d}, J=8.1 \mathrm{~Hz}, 2 \mathrm{H}), 5.19(\mathrm{~s}, 2 \mathrm{H}), 2.15(\mathrm{~s}, 3 \mathrm{H}) .{ }^{13} \mathrm{C}$ NMR $\left(101 \mathrm{MHz}, \mathrm{CDCl}_{3}\right) \delta 171.97,170.91,142.10$, 130.61, 129.18, 127.86, 65.59, 21.03. ESI LRMS (m/z): [M-H] calculated for $\mathrm{C}_{10} \mathrm{H}_{10} \mathrm{O}_{4}$ 193.05; found 193.11. 
<smiles>CC(=O)OCc1ccc(C(=O)C[N+](=O)[O-])cc1</smiles>

4-(2-nitroacetyl)benzyl acetate (S9): CDI (1.92 g, $11.9 \mathrm{mmol}, 1.1$ eq.) was added to a solution of S8 (2.1 $\mathrm{g}, 10.8 \mathrm{mmol}, 1$ eq.) in dry THF $(15 \mathrm{~mL})$. The reaction was stirred for $3 \mathrm{~h}$ at room temperature. Nitromethane $(1.7 \mathrm{~mL}, 32.4 \mathrm{mmol}, 3$ eq.) was added slowly followed by DBU $(7.3 \mathrm{~mL}, 48.7 \mathrm{mmol}, 4.5$ eq.). The reaction was stirred overnight at room temperature and then partitioned between EtOAc and 1 $\mathrm{N} \mathrm{HCl}$. The organic layer was collected, washed several times with water, dried over anhydrous sodium sulfate, and filtered. The solvent was removed under reduced pressure and the product was precipitated from DCM. Air-drying afforded the title compound as an off-white solid $(2.47 \mathrm{~g}, 95 \%$ yield). This product was used without further purification. ${ }^{1} \mathrm{H}$ NMR $\left(400 \mathrm{MHz}, \mathrm{CDCl}_{3}\right) \delta 7.93-7.81(\mathrm{~m}, 2 \mathrm{H}), 7.58-7.47(\mathrm{~m}$, $2 \mathrm{H}), 5.88(\mathrm{~s}, 2 \mathrm{H}), 5.19(\mathrm{~s}, 2 \mathrm{H}), 2.15(\mathrm{~s}, 3 \mathrm{H})$. ESI LRMS (m/z): [M-H] calculated for $\mathrm{C}_{11} \mathrm{H}_{11} \mathrm{NO}_{5} 236.06$; found 236.07. ESI HRMS (m/z): [M-H] ${ }^{-}$calculated for $\mathrm{C}_{11} \mathrm{H}_{11} \mathrm{NO}_{5} 236.0559$; found 236.0562. These data are consistent with reported values. ${ }^{21}$<smiles>O=C(c1ccc(CO)cc1)c1no[n+]([O-])c1C(=O)c1ccc(CO)cc1</smiles>

3,4-bis(4-(hydroxymethyl)benzoyl)-1,2,5-oxadiazole 2-oxide (14): A mixture of S9 (2.47 g, 13.79 mmol, 1 eq.) and $p$-toluenesulfonic acid monohydrate $(2.62 \mathrm{~g}, 13.79 \mathrm{mmol}, 1$ eq. $)$ in benzene $(75 \mathrm{~mL})$ was refluxed for $90 \mathrm{~min}$. The reaction was cooled and partitioned between EtOAc and water. The organic layer was dried over anhydrous sodium sulfate, filtered, and concentrated. The residue was dissolved in $\mathrm{EtOH}(5 \mathrm{~mL})$ and concentrated sulfuric acid $(1 \mathrm{~mL})$ was added. After stirring the reaction at ambient temperature for $4 \mathrm{~h}$, the solvent was removed under reduced pressure, and purified by flash column chromatography (EtOAc/hexanes). The title compound $(1.11 \mathrm{~g}, 45 \%$ yield) was obtained as an off-white solid. ${ }^{1} \mathrm{H}$ NMR $\left(400 \mathrm{MHz}, \mathrm{CDCl}_{3}\right) \delta 8.27-8.17(\mathrm{~m}, 2 \mathrm{H}), 7.93-7.82(\mathrm{~m}, 2 \mathrm{H}), 7.58-7.50(\mathrm{~m}, 4 \mathrm{H}), 4.84(\mathrm{~s}$, $2 \mathrm{H}), 4.82(\mathrm{~s}, 2 \mathrm{H}), 3.49(\mathrm{~s}, 2 \mathrm{H})$.<smiles>COC(=O)c1ccc(C(=O)c2no[n+]([O-])c2C(=O)c2ccc(C(=O)OC)cc2)cc1</smiles>

3,4-bis(4-(methoxycarbonyl)benzoyl)-1,2,5-oxadiazole 2-oxide (15): A solution of S5 (990 mg, 5.53 mmol, 1 eq.) and $p$-toluenesulfonic acid monohydrate $(1.05 \mathrm{~g}, 5.53 \mathrm{mmol}, 1$ eq. $)$ in benzene $(50 \mathrm{~mL})$ was heated at reflux for $2 \mathrm{~h}$. The resulting solution was diluted with EtOAc and washed with water. The organic layer was dried over anhydrous sodium sulfate, filtered, and concentrated under reduced pressure. The title compound (353 $\mathrm{mg}, 31 \%$ yield) was obtained after purification by flash column chromatography (EtOAc/hexanes). ${ }^{1} \mathrm{H}$ NMR $\left(400 \mathrm{MHz}, \mathrm{CDCl}_{3}\right) \delta 8.30-8.24(\mathrm{~m}, 2 \mathrm{H}), 8.23-8.16(\mathrm{~m}, 4 \mathrm{H}), 7.95-7.88(\mathrm{~m}$, $2 \mathrm{H}), 3.98(\mathrm{~s}, 3 \mathrm{H}), 3.96(\mathrm{~d}, J=1.7 \mathrm{~Hz}, 3 \mathrm{H}) .{ }^{13} \mathrm{C}$ NMR $\left(101 \mathrm{MHz}, \mathrm{CDCl}_{3}\right) \delta$ 181.41, 180.07, 165.89, 165.77, 
$153.98,136.94,136.88,136.03,135.91,130.59,130.46,130.21,129.60,111.29,52.86$. These data are in agreement with reported values. ${ }^{9}$<smiles>O=C(C[N+](=O)[O-])c1ccc(Br)cc1</smiles>

1-(4-bromophenyl)-2-nitroethan-1-one (S10): CDI (1.8 g, $10.94 \mathrm{mmol}, 1.1 \mathrm{eq}$.$) was added to a solution$ of 4-bromobenzoic acid $(2.0 \mathrm{~g}, 9.95 \mathrm{mmol}, 1$ eq.) in dry THF $(12 \mathrm{~mL})$. The reaction was stirred for $2 \mathrm{~h}$ at room temperature. Nitromethane $(1.6 \mathrm{~mL}, 29.85 \mathrm{mmol}, 3$ eq.) was added slowly followed by DBU $(6.7 \mathrm{~mL}$, $44.77 \mathrm{mmol}, 4.5 \mathrm{eq}$.). The reaction was stirred overnight at room temperature and then partitioned between EtOAc and $1 \mathrm{~N} \mathrm{HCl}$. The organic layer was collected, washed several times with water, dried over anhydrous sodium sulfate, and filtered. The solvent was removed under reduced pressure and the product was precipitated from DCM. Air-drying afforded the title compound as an off-white solid $(2.3 \mathrm{~g}, 95 \%$ yield). This product was used without further purification. ${ }^{1} \mathrm{H}$ NMR $\left(400 \mathrm{MHz}, \mathrm{DMSO}-\mathrm{d}_{6}\right) \delta 7.91-7.79(\mathrm{~m}, 2 \mathrm{H})$, 6.53 (s, 1H). ESI LRMS (m/z): [M-H] calculated for $\mathrm{C}_{8} \mathrm{H}_{6} \mathrm{BrNO}_{3}$ 241.95; found 242.01. ESI HRMS (m/z): [M$\mathrm{H}]^{-}$calculated for $\mathrm{C}_{8} \mathrm{H}_{6} \mathrm{BrNO}_{3}$ 241.9453; found 241.9452. These data are in agreement with reported values. ${ }^{22}$<smiles>O=C(c1ccc(Br)cc1)c1no[n+]([O-])c1C(=O)c1ccc(Br)cc1</smiles>

3,4-bis(4-bromobenzoyl)-1,2,5-oxadiazole 2-oxide (17): A solution of $\mathbf{S 1 0}$ (650 mg, $2.66 \mathrm{mmol}, 1$ eq.) and $p$-toluenesulfonic acid monohydrate $(506 \mathrm{mg}, 2.66 \mathrm{mmol}, 1$ eq.) in benzene $(30 \mathrm{~mL})$ was heated at reflux for $2 \mathrm{~h}$. The resulting solution was diluted with EtOAc and washed with water. The organic layer was dried over anhydrous sodium sulfate, filtered, and concentrated under reduced pressure. The title compound (166 mg, $28 \%$ yield) was obtained by recrystallization from ethanol. ${ }^{1} \mathrm{H} \mathrm{NMR}\left(400 \mathrm{MHz}, \mathrm{CDCl}_{3}\right)$ $\delta 8.16-8.03(\mathrm{~m}, 2 \mathrm{H}), 7.78-7.65(\mathrm{~m}, 6 \mathrm{H}) .{ }^{13} \mathrm{C}$ NMR $\left(101 \mathrm{MHz}, \mathrm{CDCl}_{3}\right) \delta$ 180.83, 179.54, 154.11, 132.87, $132.66,132.58,132.03,131.45,131.09,111.40$. These data are in agreement with reported values. ${ }^{9}$<smiles>O=C(C[N+](=O)[O-])c1cccs1</smiles>

2-nitro-1-(thiophen-2-yl)ethan-1-one (S11): CDI (1.39 g, $8.58 \mathrm{mmol}, 1.1 \mathrm{eq}$.) was added to a solution of 2-thiophenecarboxylic acid $(1.00 \mathrm{~g}, 11.02 \mathrm{mmol}, 1 \mathrm{eq}$.) in dry THF $(9 \mathrm{~mL})$. The reaction was stirred at room temperature for $2 \mathrm{~h}$. Nitromethane $(1.43 \mathrm{~g}, 1.26 \mathrm{~mL}, 23.41 \mathrm{mmol}, 3$ eq.) was added followed by DBU (5.35g, $5.25 \mathrm{~mL}, 35.12 \mathrm{mmol}, 4.5$ eq.). The reaction was stirred overnight at room temperature and then partitioned between EtOAc and $1 \mathrm{~N} \mathrm{HCl}$. The organic layer was collected, washed with water, dried over anhydrous sodium sulfate, filtered, and concentrated in vacuo to afford the title compound $(1.00 \mathrm{~g}, 75 \%$ yield) as an off-white solid. The material was used directly in the next step without further purification. ${ }^{1} \mathrm{H}$ $\operatorname{NMR}\left(300 \mathrm{MHz}, \mathrm{CDCl}_{3}\right) \delta 7.84(\mathrm{dd}, J=5.0,1.1 \mathrm{~Hz}, 1 \mathrm{H}), 7.73(\mathrm{dd}, J=3.9,1.1 \mathrm{~Hz}, 1 \mathrm{H}), 7.22(\mathrm{dd}, J=4.9$, $3.9 \mathrm{~Hz}, 1 \mathrm{H}), 5.76(\mathrm{~s}, 2 \mathrm{H}) .{ }^{13} \mathrm{C}$ NMR $\left(101 \mathrm{MHz}, \mathrm{CDCl}_{3}\right) \delta 178.24,140.07,136.86,133.72,128.95,80.86$. IR (ATR) vmax $\left(\mathrm{cm}^{-1}\right)$ 3110, 3098, 3016, 2960, 2932, 1677, 1670, 1556, 1519, 1413, 1402, 1385, 1356, 1325, 1249, 1241, 1197, 1095, 1070, 961, 913, 856, 841, 743, 732, 669, 600, 575. ESI LRMS (m/z): [M- 
$\mathrm{HJ}{ }^{-}$calculated for $\mathrm{C}_{6} \mathrm{H}_{5} \mathrm{NO}_{3} \mathrm{~S}$ 169.99; found 170.01. These data are in good agreement with literature values. ${ }^{23}$<smiles>O=C(c1cccs1)c1no[n+]([O-])c1C(=O)c1cccs1</smiles>

3,4-di(thiophene-2-carbonyl)-1,2,5-oxadiazole 2-oxide (18): A mixture of S11 (474 mg, $2.77 \mathrm{mmol}, 1$ eq.) and p-toluenesulfonic acid monohydrate $(526 \mathrm{mg}, 2.77 \mathrm{mmol}, 1$ eq.) in benzene $(35 \mathrm{~mL})$ was refluxed for $1 \mathrm{~h}$. The reaction was cooled and partitioned between EtOAc and water. The organic layer was dried over anhydrous sodium sulfate, filtered, and concentrated. The crude residue was purified by flash column chromatography (EtOAc/hexanes). Recrystallization from EtOH afforded the title compound (156 mg, 37\% yield) as a yellow solid. ${ }^{1} \mathrm{H}$ NMR $\left(400 \mathrm{MHz}, \mathrm{CDCl}_{3}\right) \delta 8.35-8.27(\mathrm{~m}, 1 \mathrm{H}), 7.95-7.85(\mathrm{~m}$, $2 \mathrm{H}), 7.78-7.71(\mathrm{~m}, 1 \mathrm{H}), 7.29-7.26(\mathrm{~m}, 1 \mathrm{H}), 7.23-7.19(\mathrm{~m}, 1 \mathrm{H}) .{ }^{13} \mathrm{C} \mathrm{NMR}\left(101 \mathrm{MHz}, \mathrm{CDCl}_{3}\right) \delta 173.32$, 171.57, 153.66, 140.58, 140.07, 138.11, 138.09, 137.39, 136.31, 129.21, 129.11, 111.36. IR (ATR) vmax $\left(\mathrm{cm}^{-1}\right) 3102,1663,1638,1600,1510,1403,1354,1329,1246,1222,1080,1049,1020,908,889,775$, 754, 724, 691, 675, 660, 561, 507. ESI LRMS (m/z): $[1 / 2 \mathrm{M}+\mathrm{H}]^{+}$calculated for $\mathrm{C}_{12} \mathrm{H}_{6} \mathrm{~N}_{2} \mathrm{O}_{4} \mathrm{~S}_{2}$ 154.00; found 154.04. ESI HRMS (m/z): $[\mathrm{M}+\mathrm{H}]^{+}$calculated for $\mathrm{C}_{12} \mathrm{H}_{6} \mathrm{~N}_{2} \mathrm{O}_{4} \mathrm{~S}_{2} 306.9847$; found 306.9842. These data are in agreement with reported values. ${ }^{9}$<smiles>O=C(C[N+](=O)[O-])C12CC3CC(CC(C3)C1)C2</smiles>

1-(adamantan-1-yl)-2-nitroethan-1-one (S12): CDI (990 mg, $6.10 \mathrm{mmol}, 1.1 \mathrm{eq}$.$) was added to a$ solution of 1-adamantanecarboxylic acid $(1.00 \mathrm{~g}, 5.55 \mathrm{mmol}, 1 \mathrm{eq}$.) in dry THF $(6 \mathrm{~mL})$. The reaction was stirred for $1 \mathrm{~h}$ at room temperature. Nitromethane $(0.89 \mathrm{~mL}, 16.64 \mathrm{mmol}, 3 \mathrm{eq}$.) was added followed by DBU (3.73 mL, $24.97 \mathrm{mmol}, 4.5$ eq.). The reaction was stirred overnight at room temperature and then partitioned between EtOAc and aqueous $1 \mathrm{~N} \mathrm{HCl}$. The organic layer was collected, dried over anhydrous sodium sulfate, and filtered, and concentrated. The resulting solid was recrystallized from EtOH to afford the title compound $\left(1.01 \mathrm{~g}, 81 \%\right.$ yield) was a white solid. ${ }^{1} \mathrm{H}$ NMR $\left(400 \mathrm{MHz}\right.$, DMSO- $\left.d_{6}\right) \delta 5.99(\mathrm{~s}, 2 \mathrm{H})$, $2.00(\mathrm{p}, J=3.1 \mathrm{~Hz}, 3 \mathrm{H}), 1.79(\mathrm{~d}, J=3.0 \mathrm{~Hz}, 6 \mathrm{H}), 1.67(\mathrm{qt}, J=9.4,5.1 \mathrm{~Hz}, 6 \mathrm{H}) .{ }^{13} \mathrm{C}$ NMR $(101 \mathrm{MHz}$, DMSO-d $\left.d_{6}\right) \delta 203.57,82.17,46.08,36.99,36.13,27.56$. IR (ATR) vmax $\left(\mathrm{cm}^{-1}\right) 2905,2850,1713,1552$, 1454, 1413, 1381, 1344, 1328, 1305, 1199, 1166, 1013, 658. ESI LRMS (m/z): [M-H] $]^{-}$calculated for $\mathrm{C}_{12} \mathrm{H}_{17} \mathrm{NO}_{3} 222.11$; found 222.11.<smiles>O=C(c1no[n+]([O-])c1C(=O)C12CC3CC(CC(C3)C1)C2)C12CC3CC(CC(C3)C1)C2</smiles>

3,4-di(adamantane-1-carbonyl)-1,2,5-oxadiazole 2-oxide (19): A solution of S12 (1.0 g, $4.48 \mathrm{mmol}, 1$ eq.) and $p$-toluenesulfonic acid monohydrate $(852 \mathrm{mg}, 4.48 \mathrm{mmol}, 1$ eq.) in benzene $(50 \mathrm{~mL})$ was refluxed for $1 \mathrm{~h}$. The reaction was cooled, diluted with EtOAc, and washed with water. The organic fraction was dried over anhydrous sodium sulfate, filtered, and concentrated. Recrystallization of the crude product from EtOH afforded the title compound $\left(222 \mathrm{mg}, 24 \%\right.$ yield) as a white solid. ${ }^{1} \mathrm{H}$ NMR (400 $\left.\mathrm{MHz}, \mathrm{CDCl}_{3}\right) \delta 2.19-2.02(\mathrm{~m}, 12 \mathrm{H}), 1.99-1.90(\mathrm{~m}, 6 \mathrm{H}), 1.85-1.66(\mathrm{~m}, 12 \mathrm{H}) .{ }^{13} \mathrm{C} \mathrm{NMR}(101 \mathrm{MHz}$, 
$\left.\mathrm{CDCl}_{3}\right) \delta 196.75,195.93,153.36,112.24,48.48,47.48,37.75,37.39,36.47,36.30,27.84,27.81 . \mathrm{IR}$ (ATR) vmax $\left(\mathrm{cm}^{-1}\right)$ 2906, 2852, 1714, 1685, 1610, 1453, 1344, 1300, 1204, 1174, 1009, 987, 951, 930, $916,806,781,760,745,667$. The title compound was unable to be detected by ESI-MS.<smiles>Cc1cc(C(=O)C[N+](=O)[O-])no1</smiles>

1-(5-methylisoxazol-3-yl)-2-nitroethan-1-one (S13): CDI (1.4 g, $8.65 \mathrm{mmol}, 1.1$ eq.) was added to a solution of 5-methylisoxazole-3-carboxylic acid (1 g, $7.87 \mathrm{mmol}, 1$ eq.) in dry THF $(9 \mathrm{~mL})$. The reaction was stirred for $1 \mathrm{~h}$ at room temperature. Nitromethane $(1.27 \mathrm{~mL}, 23.60 \mathrm{mmol}, 3$ eq.) was added followed by DBU $(5.3 \mathrm{~mL}, 35.41 \mathrm{mmol}, 4.5$ eq.). The reaction was stirred overnight at room temperature and then partitioned between EtOAc and aqueous $1 \mathrm{~N} \mathrm{HCl}$. The organic layer was collected, dried over anhydrous sodium sulfate, and filtered, and concentrated. Purification by flash column chromatography (EtOAc/hexanes) afforded the title compound $\left(1.18 \mathrm{~g}, 88 \%\right.$ yield) was a white solid. ${ }^{1} \mathrm{H}$ NMR $(400 \mathrm{MHz}$, $\left.\mathrm{CDCl}_{3}\right) \delta 6.49(\mathrm{q}, J=0.9 \mathrm{~Hz}, 1 \mathrm{H}), 5.87(\mathrm{~s}, 2 \mathrm{H}), 2.53(\mathrm{~d}, J=0.9 \mathrm{~Hz}, 3 \mathrm{H}) .{ }^{13} \mathrm{C} \mathrm{NMR}\left(101 \mathrm{MHz}, \mathrm{CDCl}_{3}\right) \delta$ 180.50, 172.85, 159.90, 100.46, 80.90, 12.48. IR (ATR) vmax $\left(\mathrm{cm}^{-1}\right)$ 1724, 1596, 1557, 1449, 1396, 1377 , 1317, 1249, 1186, 1145, 1043, 1005, 954, 933, 850, 811, 702, 652, 586, 544. ESI LRMS (m/z): [M-H] calculated for $\mathrm{C}_{6} \mathrm{H}_{6} \mathrm{~N}_{2} \mathrm{O}_{4}$ 169.03; found 168.91.<smiles>Cc1cc(C(=O)c2no[n+]([O-])c2C(=O)c2cc(C)on2)no1</smiles>

3,4-bis(5-methylisoxazole-3-carbonyl)-1,2,5-oxadiazole 2-oxide (20): A solution of $\mathbf{S 1 3}$ (500 mg, 2.92 mmol, 1 eq.) and $p$-toluenesulfonic acid monohydrate $(555 \mathrm{mg}, 2.92 \mathrm{mmol}, 1$ eq.) in benzene ( $35 \mathrm{~mL})$ was refluxed for $4 \mathrm{~h}$. The reaction was cooled and partitioned between EtOAc and water. The organic layer was dried over anhydrous sodium sulfate, filtered, and concentrated. The crude residue was purified by flash column chromatography (EtOAc/hexanes). Recrystallization from EtOH afforded the title compound $\left(61 \mathrm{mg}, 14 \%\right.$ yield) as a white solid. ${ }^{1} \mathrm{H}$ NMR $\left(400 \mathrm{MHz}, \mathrm{CDCl}_{3}\right) \delta 6.54-6.51(\mathrm{~m}, 1 \mathrm{H}), 6.51-$ $6.46(\mathrm{~m}, 1 \mathrm{H}), 2.53-2.50(\mathrm{~m}, 3 \mathrm{H}), 2.48-2.45(\mathrm{~m}, 3 \mathrm{H}) .{ }^{13} \mathrm{C} \mathrm{NMR}\left(101 \mathrm{MHz}, \mathrm{CDCl}_{3}\right) \delta$ 175.06, 172.74, 172.38, 172.02, 160.83, 160.44, 152.69, 110.47, 101.35, 100.89, 12.47. IR (ATR) vmax $\left(\mathrm{cm}^{-1}\right) 3143$, $1709,1596,1450,1412,1254,1163,1142,1050,1005,934,902,869,814,770,657,641$. IR data are consistent with previously reported values. ${ }^{17}$ The title compound was unable to be detected by ESI-MS.

\section{General Procedure for the Synthesis of 4-Nitroisoxazoles}

A procedure for the synthesis of 4-nitroisoxazoles from a-nitroketones was adapted from a report by Trogu et al. ${ }^{24} \mathrm{~A}$ solution of $\alpha$-nitroketone (1 eq.) was dissolved in chloroform $(0.75 \mathrm{M})$ that had been filtered through a short pad of potassium carbonate immediately before use. DABCO (0.08 eq.) and copper(II) acetate (0.04 eq.) were added and the reaction was stirred at $60{ }^{\circ} \mathrm{C}$ for $24-48 \mathrm{~h}$. The reaction was cooled concentrated in vacuo. Purification by flash column chromatography (0-20\% EtOAc/hexanes) afforded a mixture of 4-nitroisoxazole and furoxan isomers. Recrystallization from $\mathrm{EtOH}$ afforded the desired 4-nitroisoxazole.<smiles>COc1ccc(C(=O)c2noc(-c3ccc(OC)cc3)c2[N+](=O)[O-])cc1</smiles> 
(4-methoxyphenyl)(5-(4-methoxyphenyl)-4-nitroisoxazol-3-yl)methanone (21): Following the General Procedure with $\mathbf{S 1}$ afforded the title compound (32 $\mathrm{mg}, 12 \%$ yield) as a yellow solid. Sample was approximately $90 \%$ pure with the remaining impurity the furoxan isomer $1 .{ }^{1} \mathrm{H} \mathrm{NMR}\left(400 \mathrm{MHz}, \mathrm{CDCl}_{3}\right) \delta$ $8.09-8.04(\mathrm{~m}, 2 \mathrm{H}), 8.04-7.99(\mathrm{~m}, 2 \mathrm{H}), 7.12-7.05(\mathrm{~m}, 2 \mathrm{H}), 7.06-6.98(\mathrm{~m}, 2 \mathrm{H}), 3.93(\mathrm{~s}, 3 \mathrm{H}), 3.91(\mathrm{~s}$, $3 \mathrm{H})$. ESI LRMS (m/z): $[\mathrm{M}+\mathrm{H}]^{+}$calculated for $\mathrm{C}_{18} \mathrm{H}_{14} \mathrm{~N}_{2} \mathrm{O}_{6} 355.09$; found 355.09. ESI HRMS (m/z): $[\mathrm{M}+\mathrm{H}]^{+}$ calculated for $\mathrm{C}_{18} \mathrm{H}_{14} \mathrm{~N}_{2} \mathrm{O}_{6} 355.0930$; found 355.0923 .<smiles>Cc1ccc(C(=O)c2noc(-c3ccc(C)cc3)c2[N+](=O)[O-])cc1</smiles>

4-nitro-5-(p-tolyl)isoxazol-3-yl)(p-tolyl)methanone (22): Following the General Procedure with $\mathbf{S 2}$ afforded the title compound $\left(77 \mathrm{mg}, 17 \%\right.$ yield) as a white solid. ${ }^{1} \mathrm{H} \mathrm{NMR}\left(400 \mathrm{MHz}, \mathrm{CDCl}_{3}\right) \delta 7.94(\mathrm{~d}, \mathrm{~J}=$ $7.9 \mathrm{~Hz}, 4 \mathrm{H}), 7.40$ (d, J = 8.0 Hz, 2H), $7.35(\mathrm{~d}, J=8.0 \mathrm{~Hz}, 2 \mathrm{H}), 2.49(\mathrm{~s}, 3 \mathrm{H}), 2.47(\mathrm{~s}, 3 \mathrm{H}) .{ }^{13} \mathrm{C}$ NMR (101 $\left.\mathrm{MHz}, \mathrm{CDCl}_{3}\right) \delta 183.39,168.12,157.28,146.72,144.59,132.69,130.42,129.93,129.91,129.53,121.07$, 22.10, 21.98. Note: One carbon atom was not detected. IR (ATR) vmax $\left(\mathrm{cm}^{-1}\right) 1677,16-3,1583,1570$, $1521,1510,1466,1424,1410,1357,1320,1313,1298,1263,1238,1212,1180,1151,1122,1103$, 1037, 1021, 979, 955, 915, 896, 825, 791, 770, 751, 718, 683, 653, 638, 612, 581, 510, 476. ESI LRMS $(\mathrm{m} / \mathrm{z})$ : $[\mathrm{M}+\mathrm{H}]^{+}$calculated for $\mathrm{C}_{18} \mathrm{H}_{14} \mathrm{~N}_{2} \mathrm{O}_{4} 323.10$; found 323.18. ESI HRMS (m/z): $[\mathrm{M}+\mathrm{H}]^{+}$calculated for $\mathrm{C}_{18} \mathrm{H}_{14} \mathrm{~N}_{2} \mathrm{O}_{4}$ 323.1032; found 323.1025.<smiles>O=C(c1ccccc1)c1noc(-c2ccccc2)c1[N+](=O)[O-]</smiles>

(4-nitro-5-phenylisoxazol-3-yl)(phenyl)methanone (23): Following the General Procedure with S3 afforded the title compound (54 mg, $16 \%$ yield) as a white solid. ${ }^{1} \mathrm{H}$ NMR (400 MHz, $\left.\mathrm{CDCl}_{3}\right) \delta 8.14-8.02$ $(\mathrm{m}, 4 \mathrm{H}), 7.77-7.68(\mathrm{~m}, 2 \mathrm{H}), 7.67-7.56(\mathrm{~m}, 4 \mathrm{H}) .{ }^{13} \mathrm{C}$ NMR $\left(101 \mathrm{MHz}, \mathrm{CDCl}_{3}\right) \delta$ 183.71, 168.04, 157.11, 135.37, 135.00, 133.52, 130.32, 129.58, 129.24, 129.21, 123.84. IR (ATR) vmax (cm $\left.{ }^{-1}\right)$ 1684, 1599, 1584, 1574, 1524, 1492, 1467, 1450, 1420, 1360, 1265, 1234, 1181, 1152, 915, 895, 825, 799, 760, 729, 700, 687, 601. ESI HRMS (m/z): $[\mathrm{M}+\mathrm{H}]^{+}$calculated for $\mathrm{C}_{16} \mathrm{H}_{10} \mathrm{~N}_{2} \mathrm{O}_{4}$ 295.0719; found 295.0712. These data are in agreement with literature values. ${ }^{24}$<smiles>c1ccc(C2=NOC(c3ccccc3)=NO2)cc1</smiles>

3,6-diphenyl-1,4,2,5-dioxadiazine (24): Triethylamine (720 $\mu \mathrm{L}, 5.14 \mathrm{mmol}, 2$ eq.) was added to a solution of $\mathbf{S 4}(400 \mathrm{mg}, 2.57 \mathrm{mmol}, 1$ eq.) in $\mathrm{EtOH}(10 \mathrm{~mL})$ and pyridine $(410 \mu \mathrm{L}, 5.14 \mathrm{mmol}, 2$ eq. $)$. The reaction was stirred for $1 \mathrm{~h}$ at room temperature and then partitioned between DCM and water. The organic layer was collected and concentrated. Purification of the crude residue by flash column chromatography (EtOAc/hexanes) afforded the title compound ( $232 \mathrm{mg}, 76 \%$ yield) as a white solid. ${ }^{1} \mathrm{H}$ NMR (400 MHz, CDCl 3 ) ס $8.02-7.87(\mathrm{~m}, 4 \mathrm{H}), 7.62-7.55(\mathrm{~m}, 2 \mathrm{H}), 7.52-7.45(\mathrm{~m}, 4 \mathrm{H}) .{ }^{13} \mathrm{C}$ NMR $(101$ $\left.\mathrm{MHz}, \mathrm{CDCl}_{3}\right) \delta 162.81,132.96,128.98,127.46,125.80$. IR (ATR) vmax $\left(\mathrm{cm}^{-1}\right) 1611,1600,1569,1444$, 
$1333,1313,1296,1083,1026,1002,844,772,764,704,690,665$. These data are in agreement with reported values. ${ }^{19}$ ESI HRMS (m/z): $[\mathrm{M}+\mathrm{H}]^{+}$calculated for $\mathrm{C}_{14} \mathrm{H}_{10} \mathrm{~N}_{2} \mathrm{O}_{2} 239.0821$; found 239.0814 .<smiles>Cc1c(C(=O)c2ccccc2)[n+]([O-])c2ccccc2[n+]1[O-]</smiles>

2-benzoyl-3-methylquinoxaline 1,4-dioxide (25): A solution of benzofuroxan (200 $\mathrm{mg}, 1.47 \mathrm{mmol}, 1$ eq.), 1-phenyl-1,3-butanedione (357 mg, $2.20 \mathrm{mmol}, 1.5$ eq.), and triethylamine ( $0.1 \mathrm{~mL}, 0.73 \mathrm{mmol}, 0.5$ eq.) in dry DCM $(10 \mathrm{~mL})$ was stirred at room temperature for $24 \mathrm{~h}$. The mixture was concentrated under reduced pressure and purified by flash column chromatography (0-100\% EtOAc/hexanes). The title compound $\left(61 \mathrm{mg}, 15 \%\right.$ yield) was obtained as a yellow solid. ${ }^{1} \mathrm{H} \mathrm{NMR}\left(300 \mathrm{MHz}, \mathrm{CDCl}_{3}\right) \delta 8.74-8.66$ $(\mathrm{m}, 1 \mathrm{H}), 8.62-8.53(\mathrm{~m}, 1 \mathrm{H}), 7.99-7.82(\mathrm{~m}, 4 \mathrm{H}), 7.72-7.64(\mathrm{~m}, 1 \mathrm{H}), 7.58-7.48(\mathrm{~m}, 2 \mathrm{H}), 2.51(\mathrm{~s}, 3 \mathrm{H})$. ${ }^{13} \mathrm{C}$ NMR $\left(101 \mathrm{MHz}, \mathrm{CDCl}_{3}\right) \delta 186.76,139.79,138.92,138.21,137.16,135.41,134.54,132.70,131.62$, 129.62, 129.35, 120.42, 14.34. ESI LRMS (m/z): $[\mathrm{M}+\mathrm{H}]^{+}$calculated for $\mathrm{C}_{16} \mathrm{H}_{12} \mathrm{~N}_{2} \mathrm{O}_{3}$ 281.09; found 281.10. ESI HRMS (m/z): $[\mathrm{M}+\mathrm{H}]^{+}$calculated for $\mathrm{C}_{16} \mathrm{H}_{12} \mathrm{~N}_{2} \mathrm{O}_{3}$ 281.0926; found 281.0921. ${ }^{1} \mathrm{H}$ NMR data is in agreement with literature values. ${ }^{25}$

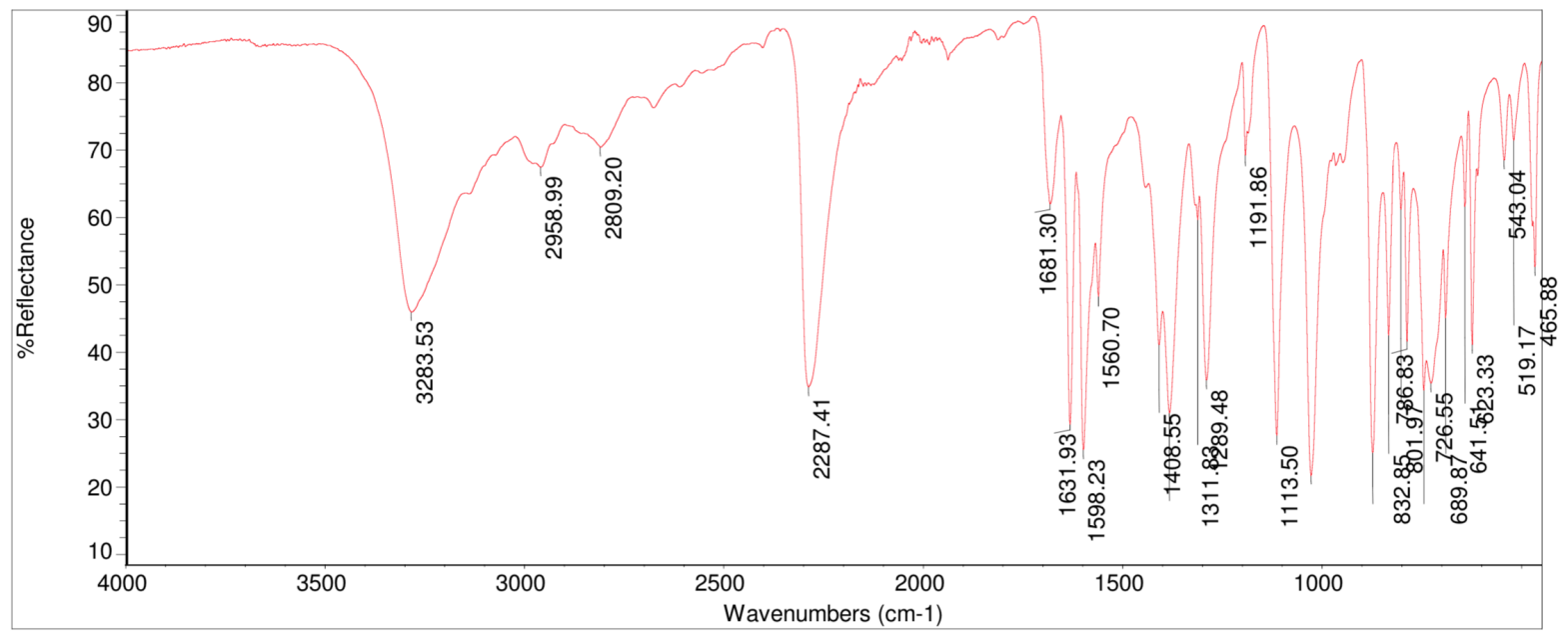

Figure S14: IR spectrum of nitrile oxide 8.

\section{References}

(1) Akaike, T.; Yoshida, M.; Miyamoto, Y.; Sato, K.; Kohno, M.; Sasamoto, K.; Miyazaki, K.; Ueda, S.; Maeda, H. Antagonistic Action of Imidazolineoxyl A-Oxides against Endothelium-Derived Relaxing Factor/NO through a Radical Reaction. Biochemistry 1993, 32, 827-832.

(2) Brittelli, D. R.; Boswell, G. A. New Furoxan Chemistry. 2. Chemistry of Acyl Nitrile Oxides Generated in Situ by Thermolysis of Diacylfuroxans. J. Org. Chem. 1981, 46 (2), 316-320.

(3) Yang, W. S.; Sriramaratnam, R.; Welsch, M. E.; Shimada, K.; Skouta, R.; Viswanathan, V. S.; Cheah, J. H.; Clemons, P. A.; Shamji, A. F.; Clish, C. B.; et al. Regulation of Ferroptotic Cancer Cell Death by GPX4. Cell 2014, 156 (1-2), 317-331.

(4) Weïwer, M.; Bittker, J. A.; Lewis, T. A.; Shimada, K.; Yang, W. S.; MacPherson, L.; Dandapani, S.; Palmer, M.; Stockwell, B. R.; Schreiber, S. L.; et al. Development of Small-Molecule Probes That Selectively Kill Cells Induced to Express Mutant RAS. Bioorganic Med. Chem. Lett. 2012, 22 (4), 1822-1826. 
(5) Eaton, J. K.; Furst, L.; Ruberto, R. A.; Moosmayer, D.; Hillig, R. C.; Hilpmann, A.; Zimmermann, K.; Ryan, M. J.; Niehues, M.; Kramm, A.; et al. Targeting a Therapy-Resistant Cancer Cell State Using Masked Electrophiles as GPX4 Inhibitors. bioRxiv 2018, doi.org/10.1101/376764.

(6) Scheerer, P.; Borchert, A.; Krauss, N.; Wessner, H.; Gerth, C.; Hohne, W.; Kuhn, H. Structural Basis for Catalytic Activity and Enzyme Polymerization of Phospholipid. Biochemistry 2007, 46 (31), 9041-9049.

(7) Sakamoto, K.; Sogabe, S.; Kamada, Y.; Matsumoto, S.; Kadotani, A.; Sakamoto, J.; Tani, A. Discovery of GPX4 Inhibitory Peptides from Random Peptide T7 Phage Display and Subsequent Structural Analysis. Biochem. Biophys. Res. Commun. 2017, 482 (2), 195-201.

(8) Takamoto, M.; Kurouchi, H.; Otani, Y.; Ohwada, T. Phenylation Reaction of ??-Acylnitromethanes to Give 1,2-Diketone Monooximes: Involvement of Carbon Electrophile at the Position a to the Nitro Group. Synthesis (Stuttg). 2009, No. 24, 4129-4136.

(9) Gu, Z. Z.; Guo, F. C.; Zhang, P.; Qin, Y. J.; Guo, Z. X. Solvent-Free Mechanochemical Synthesis of Diacylfuroxans. Tetrahedron Lett. 2019, 60 (26), 1687-1690.

(10) Lian, Z.; Friis, S. D.; Skrydstrup, T. Palladium-Catalysed Carbonylative a-Arylation of Nitromethane. Chem. Commun. 2015, 51 (17), 3600-3603.

(11) Kuwabara, J.; Sawada, Y.; Yoshimatsu, M. Copper-Mediated Reactions of Nitriles with Nitromethanes: Aza-Henry Reactions and Nitrile Hydrations. Org. Lett. 2018, 20 (4), 1130-1133. Cecchi, L.; De Sarlo, F.; Faggi, C.; Machetti, F. 1,2,5-Oxadiazole (Furazan) Derivatives from Benzoylnitromethane and Dipolarophiles in the Presence of DABCO: Structure and Intermediates. European J. Org. Chem. 2006, No. 13, 3016-3020.

(13) Wiley, R. H.; Wakefield, B. J. Infrared Spectra of the Nitrile N-Oxides: Some New Furoxans. J. Org. Chem. 1960, 25 (4), 546-551.

(14) Burakevich, J. V.; Butler, R. S.; Volpp, G. P. Phenylfurazan Oxide. Chemistry. J. Org. Chem. 1972, 37 (4), 593-596.

(15) Kalinina, M. I.; Mosiev, I. K. Properties of Furoxans Monosubstituted with Adamantanes. Chem. Heterocycl. Compd. 1988, 24, 217-220.

(16) Kalmode, H. P.; Vadagaonkar, K. S.; Shinde, S. L.; Chaskar, A. C. Metal-Free Dehomologative Oxidation of Arylacetic Acids for the Synthesis of Aryl Carboxylic Acids. J. Org. Chem. 2017, 82 (7), 3781-3786.

(17) Boyer, N. E.; Czerniak, G. M.; Gutowsky, H. S.; Snyder, H. R. The Infrared Absorption Spectra of Furoxans. J. Am. Chem. Soc. 1955, 77 (16), 4238-4241.

(18) Dubrovskiy, A. V; Larock, R. C. Synthesis of Benzisoxazoles by the [3 + 2] Cycloaddition of in Situ Generated Nitrile Oxides and Arynes. Org. Lett. 2010, 12 (6), 1180-1183.

(19) Kelly, D. R.; Baker, S. C.; King, D. S.; de Silva, D. S.; Lord, G.; Taylor, J. P. Studies of Nitrile Oxide Cycloadditions, and the Phenolic Oxidative Coupling of Vanillin Aldoxime by Geobacillus Sp. DDS012 from Italian Rye Grass Silage. Org. Biomol. Chem. 2008, 6 (4), 787.

(20) Garvey, D. S.; Ranatunge, R. R. Furoxan Compounds, Compositions and Methods of Use. WO 2007/059311, 2007.

(21) Gigante, F.; Kaiser, M.; Brun, R.; Gilbert, I. H. Design and Preparation of Sterol Mimetics as Potential Antiparasitics. Bioorganic Med. Chem. 2010, 18 (20), 7291-7301.

(22) Zeng, X.; Gao, J. J.; Song, J. J.; Ma, S.; Desrosiers, J. N.; Mulder, J. A.; Rodriguez, S.; Herbage, M. A.; Haddad, N.; Qu, B.; et al. Remarkable Enhancement of Enantioselectivity in the Asymmetric Conjugate Addition of Dimethylzinc to (Z)-Nitroalkenes with a Catalytic [(MeCN) $4 \mathrm{Cu}] P F \quad 6$ Hoveyda Ligand Complex. Angew. Chemie - Int. Ed. 2014, 53 (45), 12153-12157.

(23) Lian, Z.; Friis, S. D.; Skrydstrup, T. Palladium-Catalyzed Carbonylative $\alpha$-Arylation of Nitromethane. Chem. Commun. 2015, 51, 3600-3603.

(24) Trogu, E.; Cecchi, L.; De Sarlo, F.; Guideri, L.; Ponticelli, F.; Machetti, F. Base- and CopperCatalysed Condensation of Primary Activated Nitro Compounds with Enolisable Compounds. European J. Org. Chem. 2009, No. 34, 5971-5978.

(25) Haddadin, M. J.; Taha, M. U.; Jarrar, A. A.; Issidorides, C. H. Reaction of Benzofurazan Oxide with Unsymmetrical 1,3-Diketones; Steric and Polar Effects. Tetrahedron 1976, 32 (6), 719-724. 


\section{NMR Spectra}
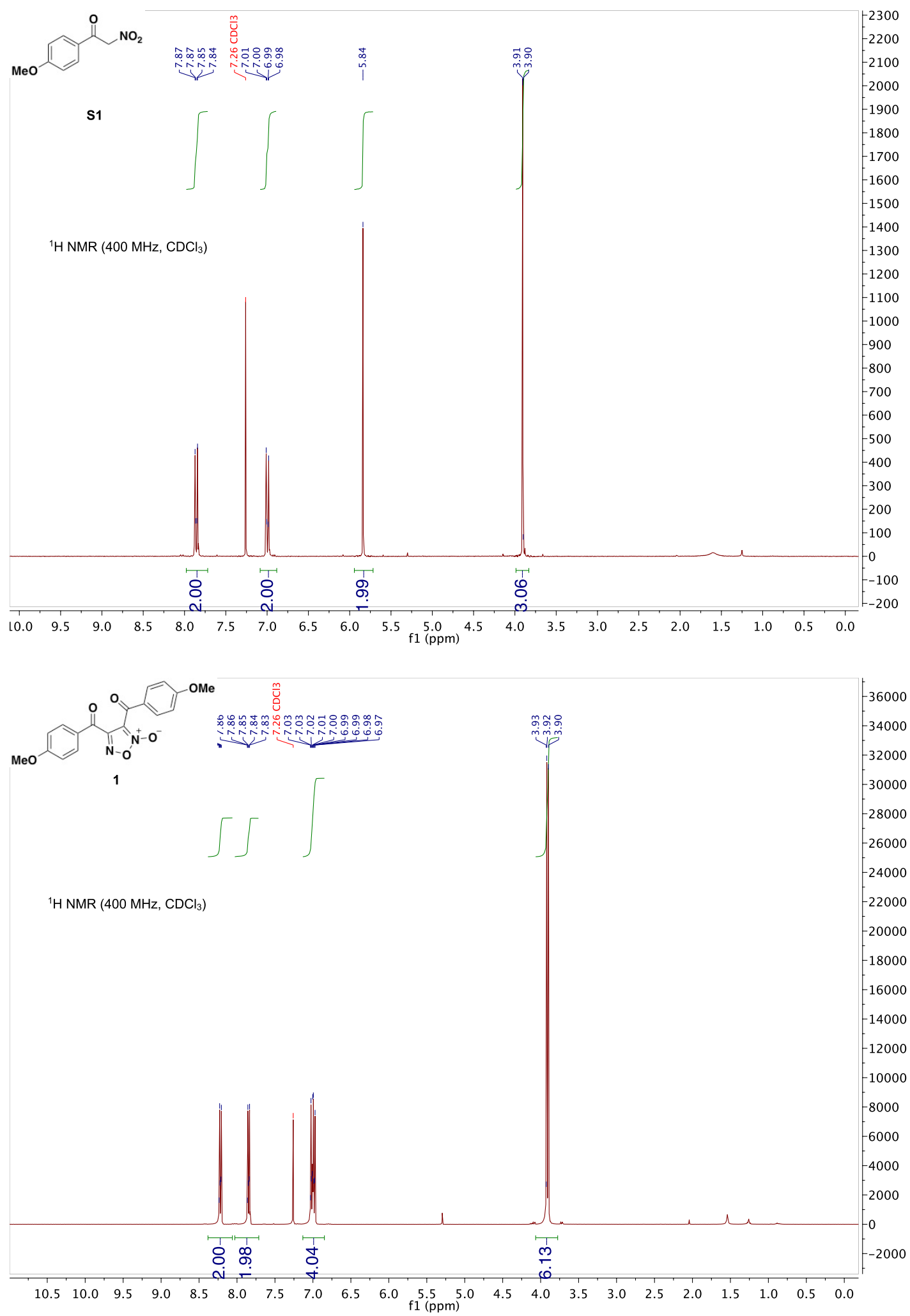

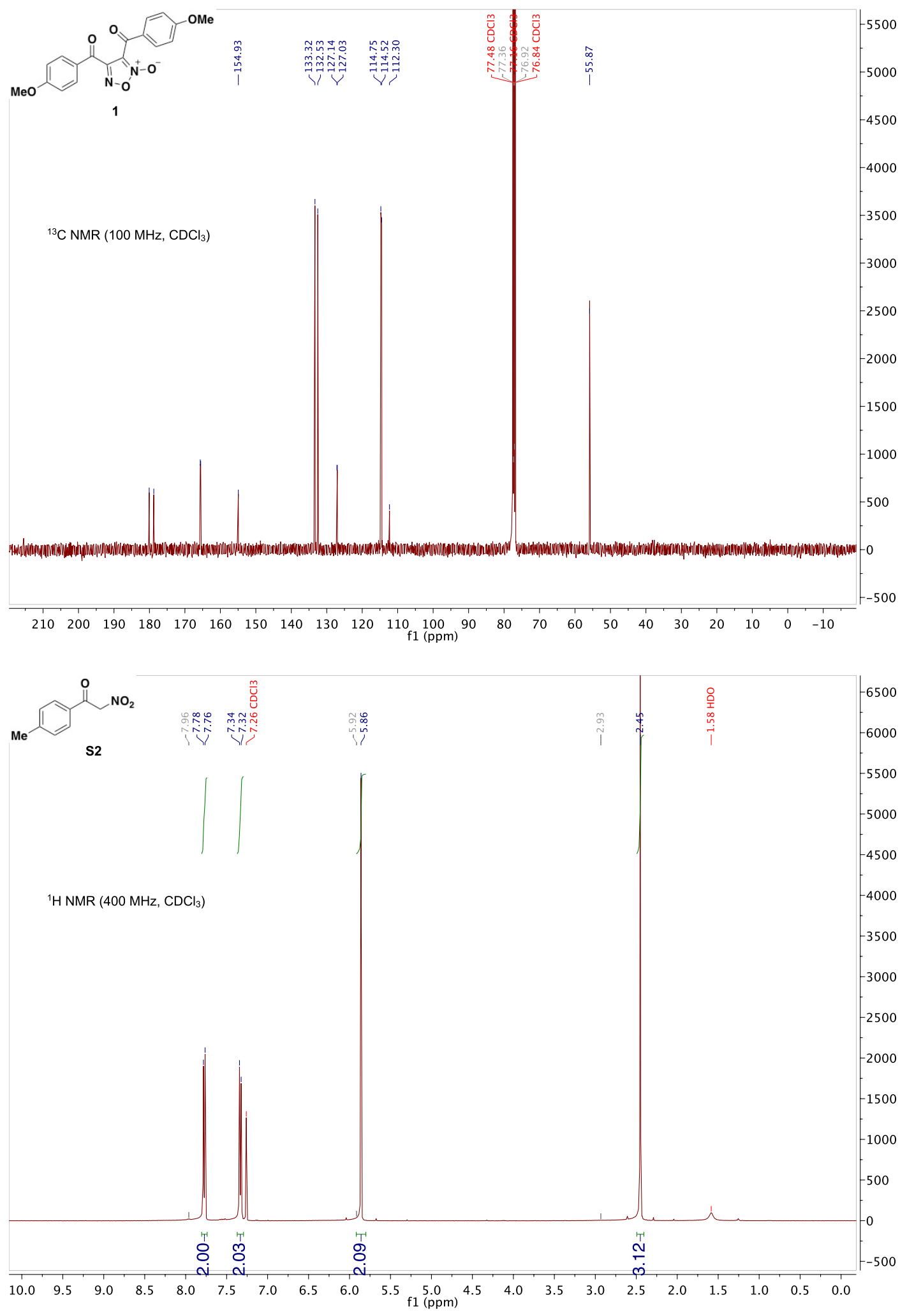

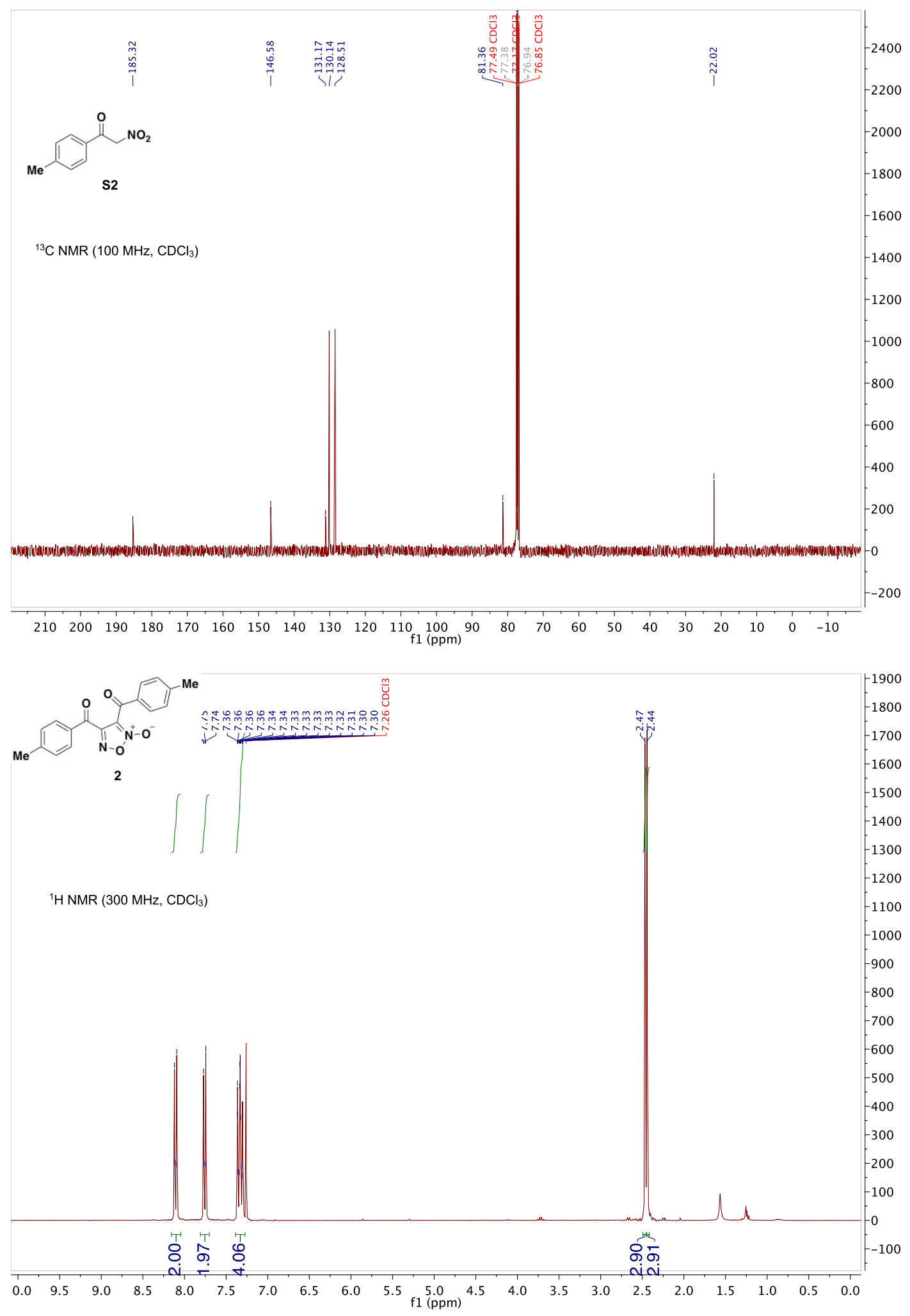

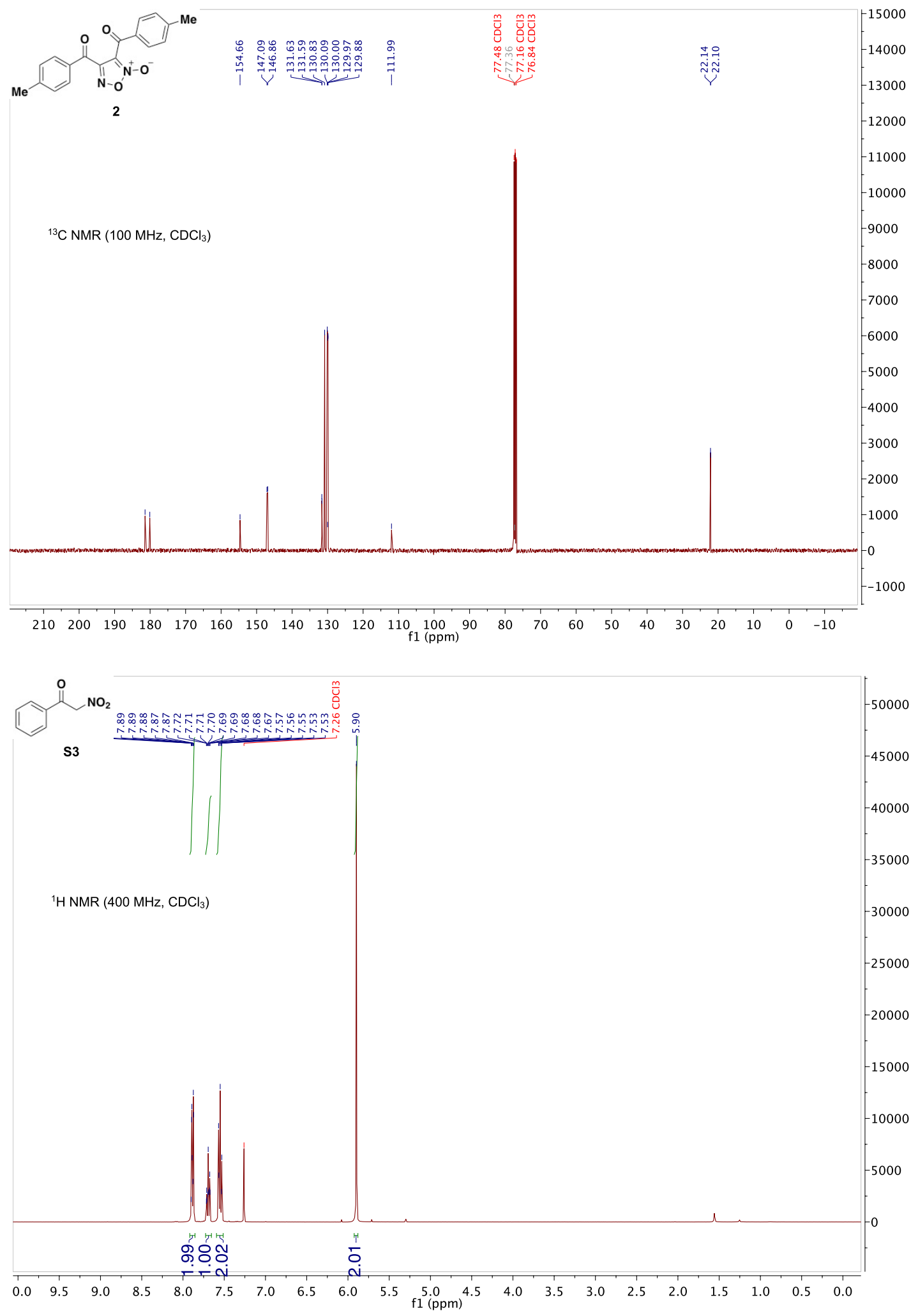

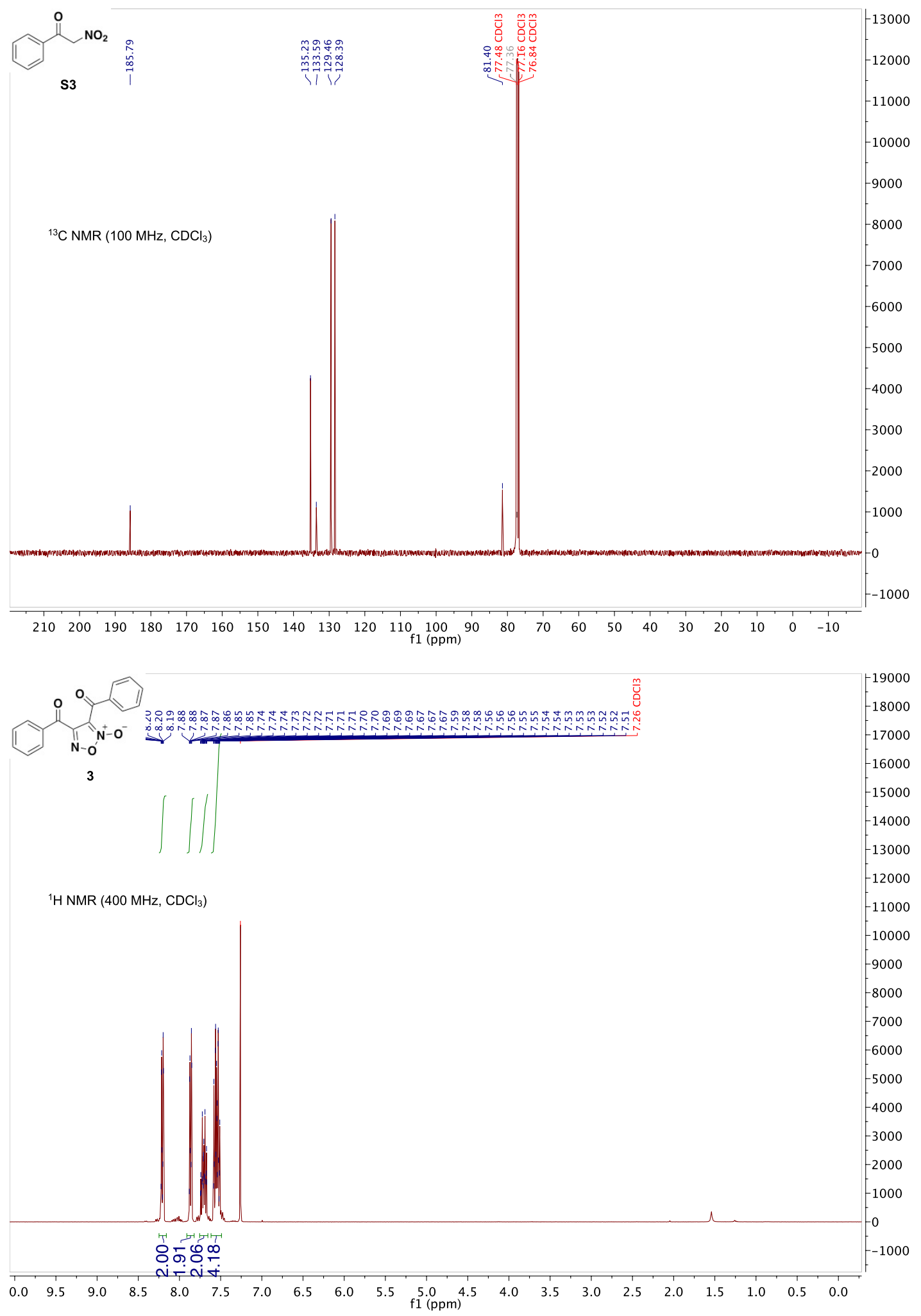


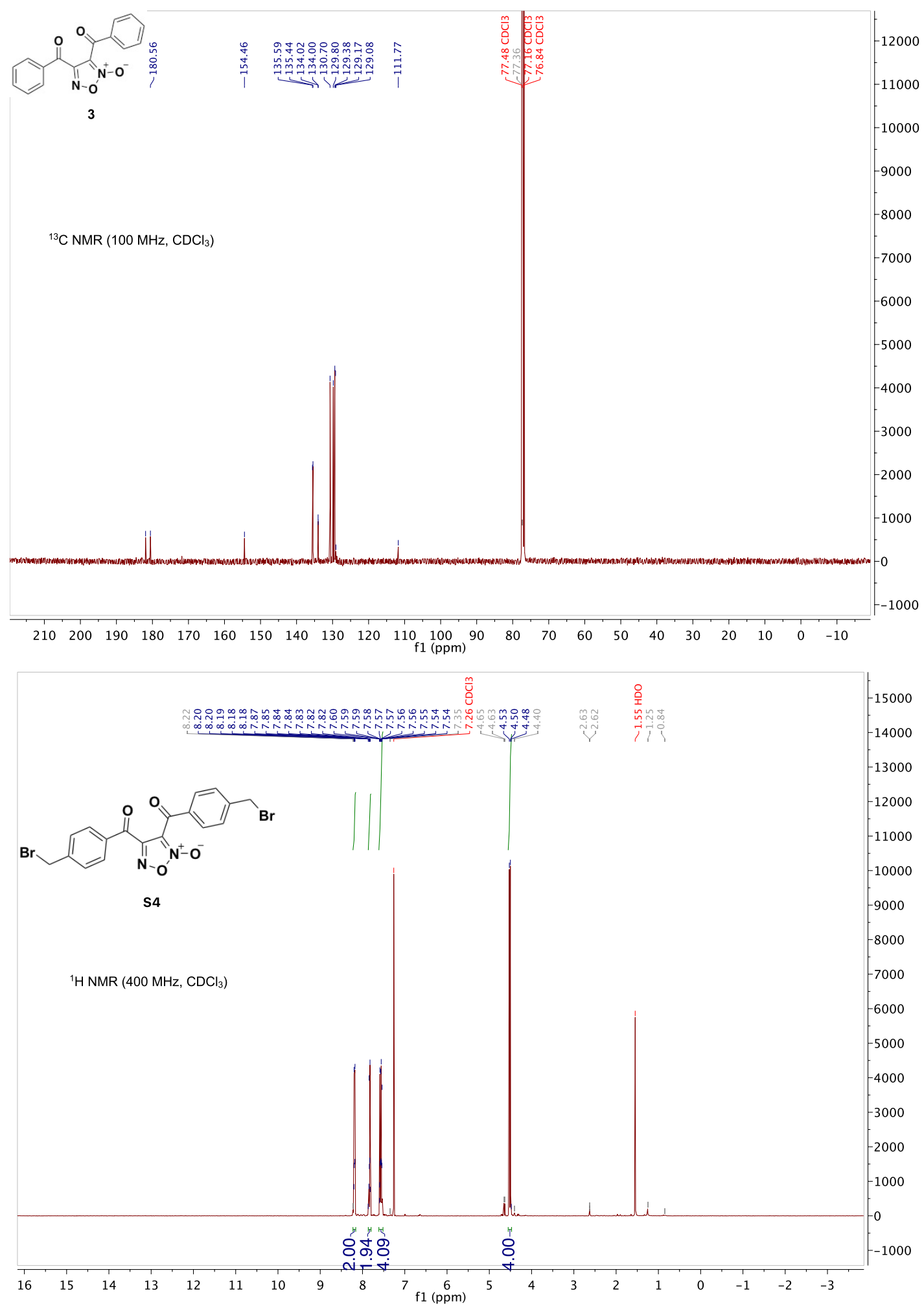




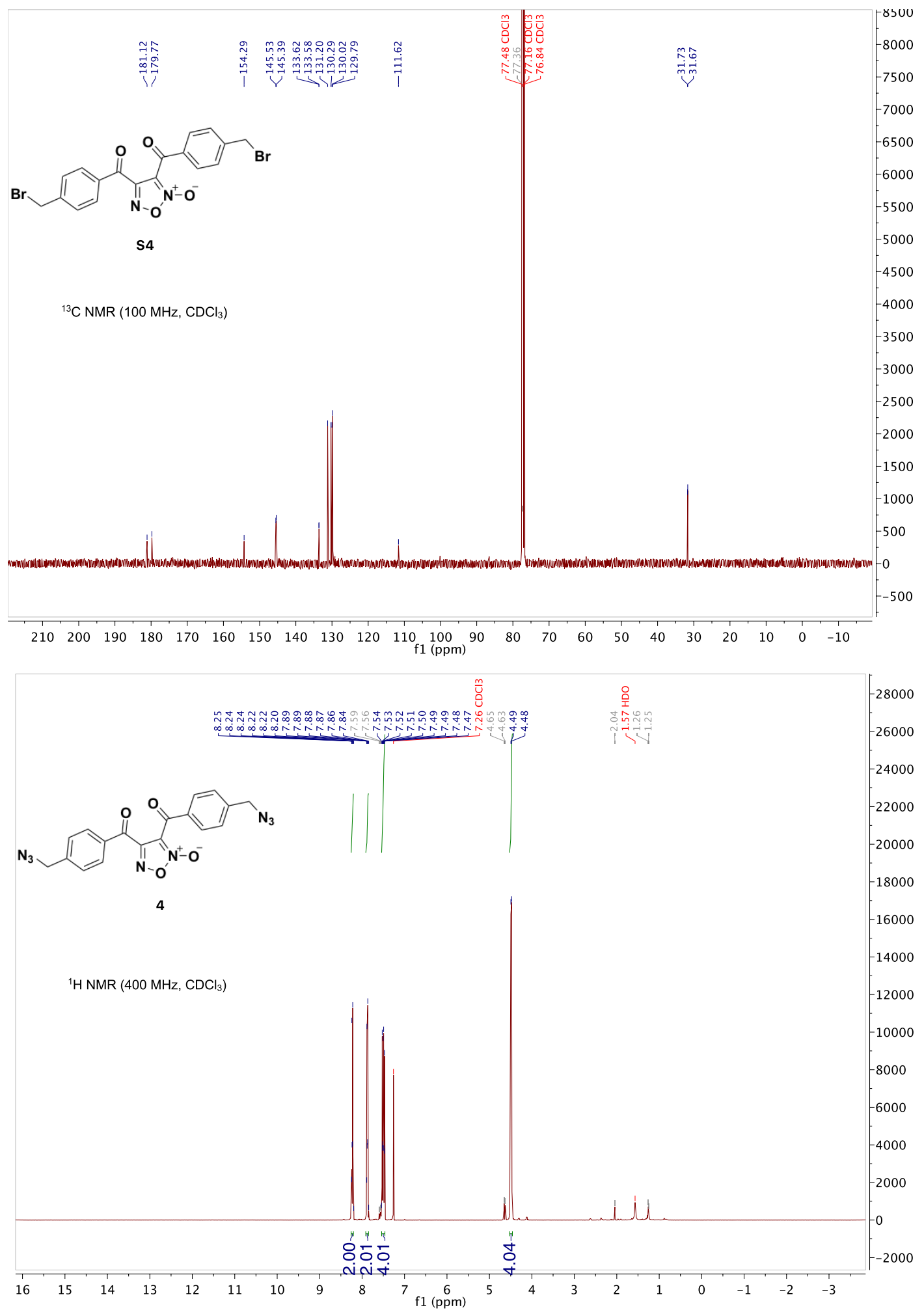



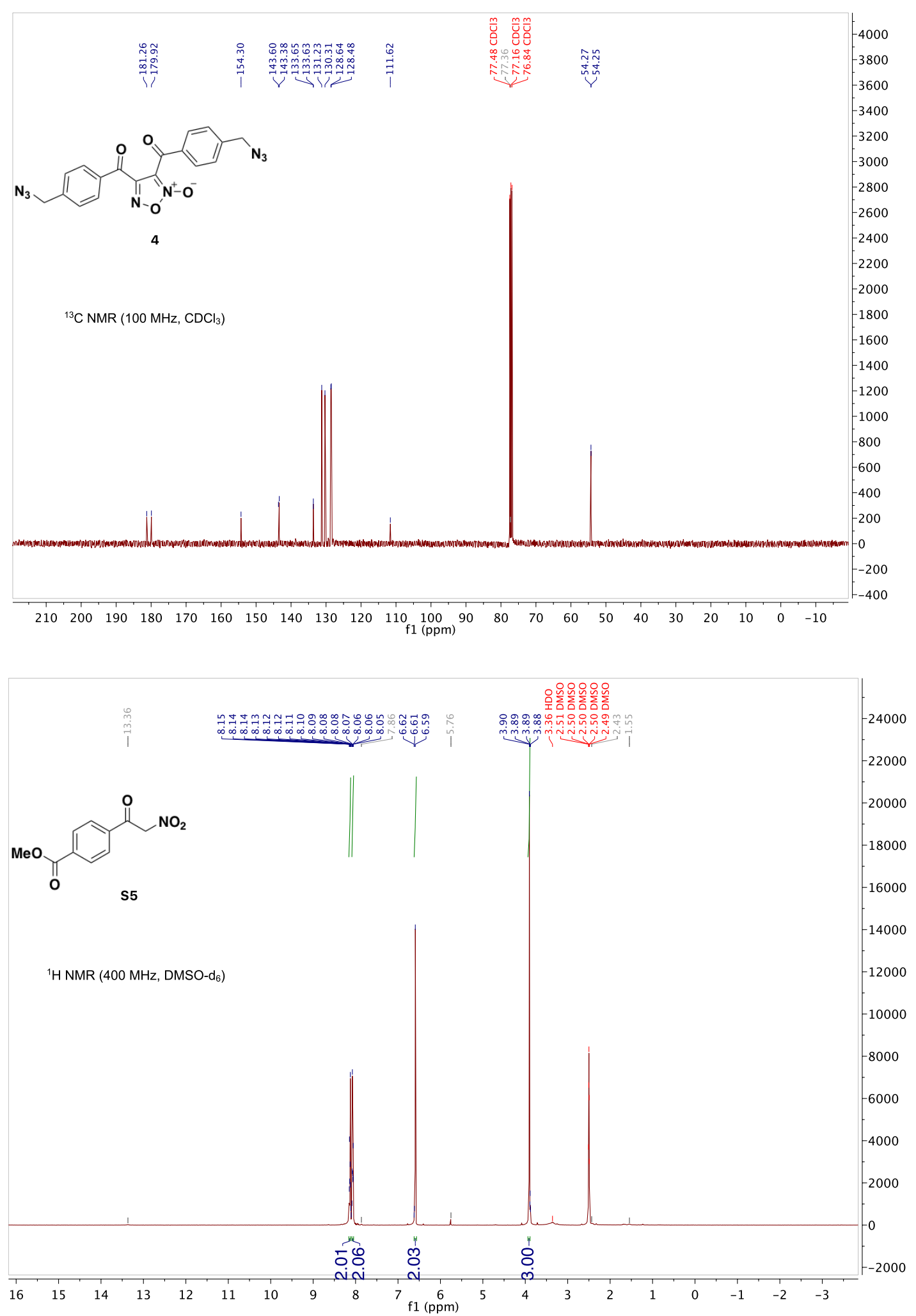


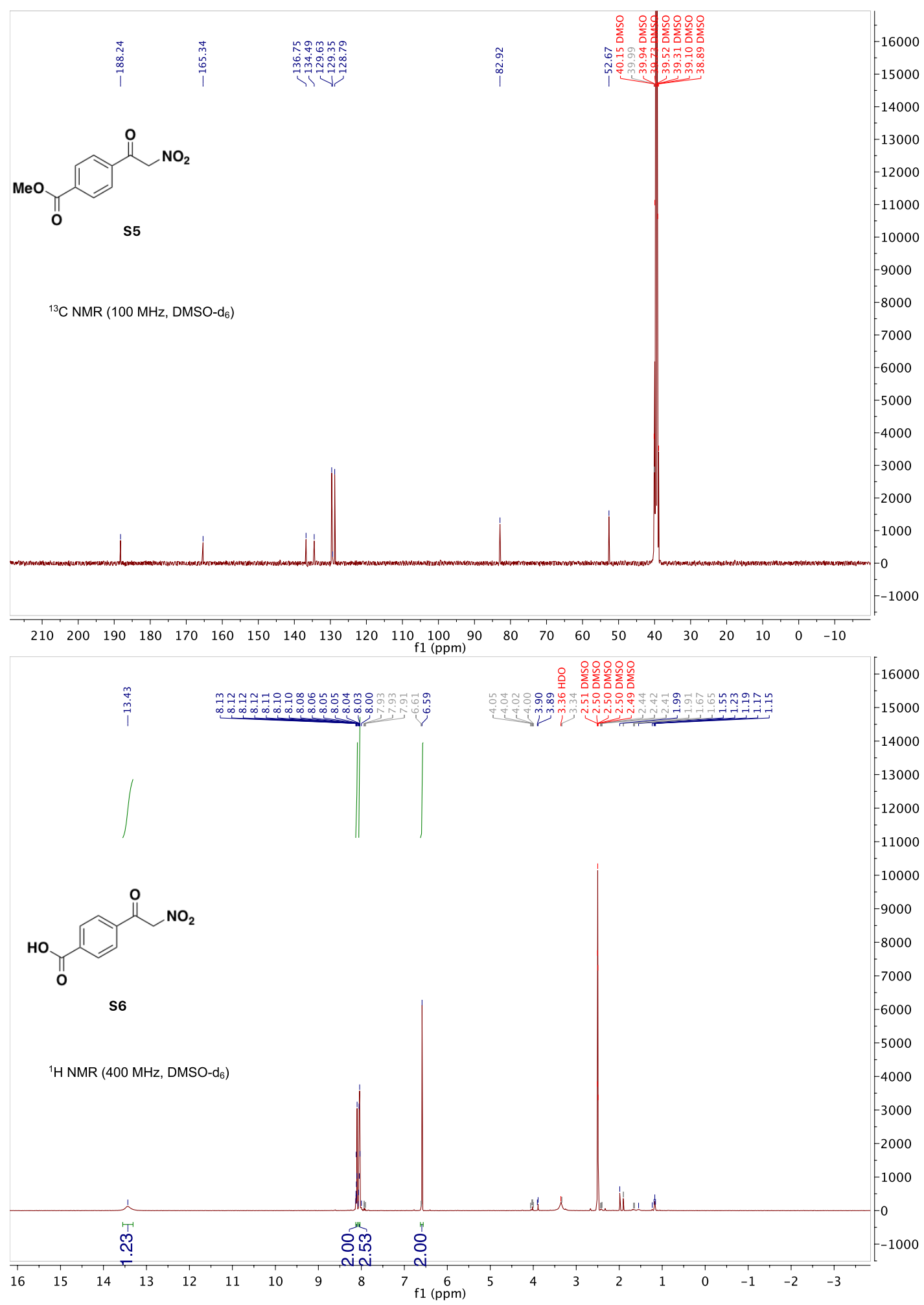




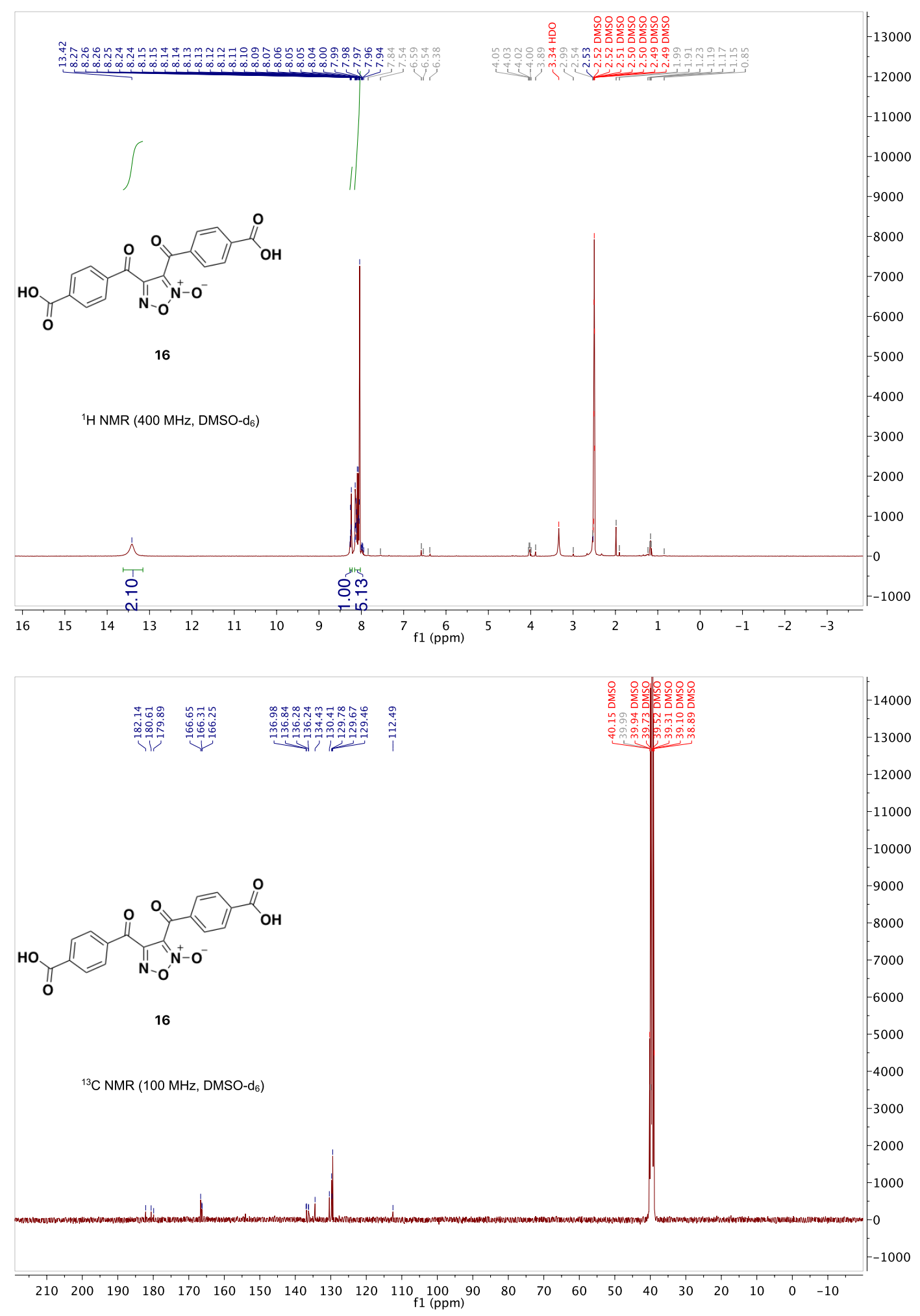



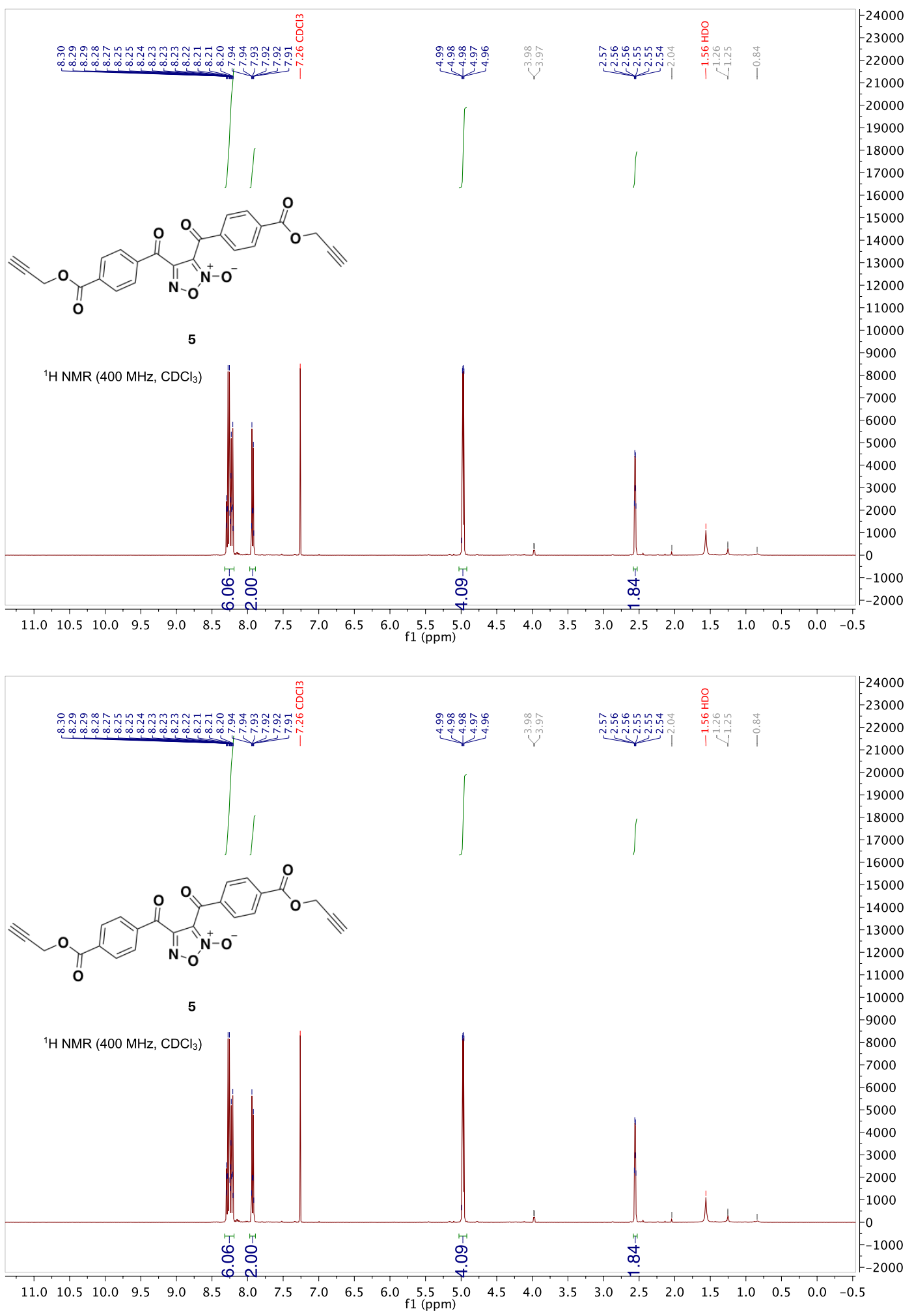

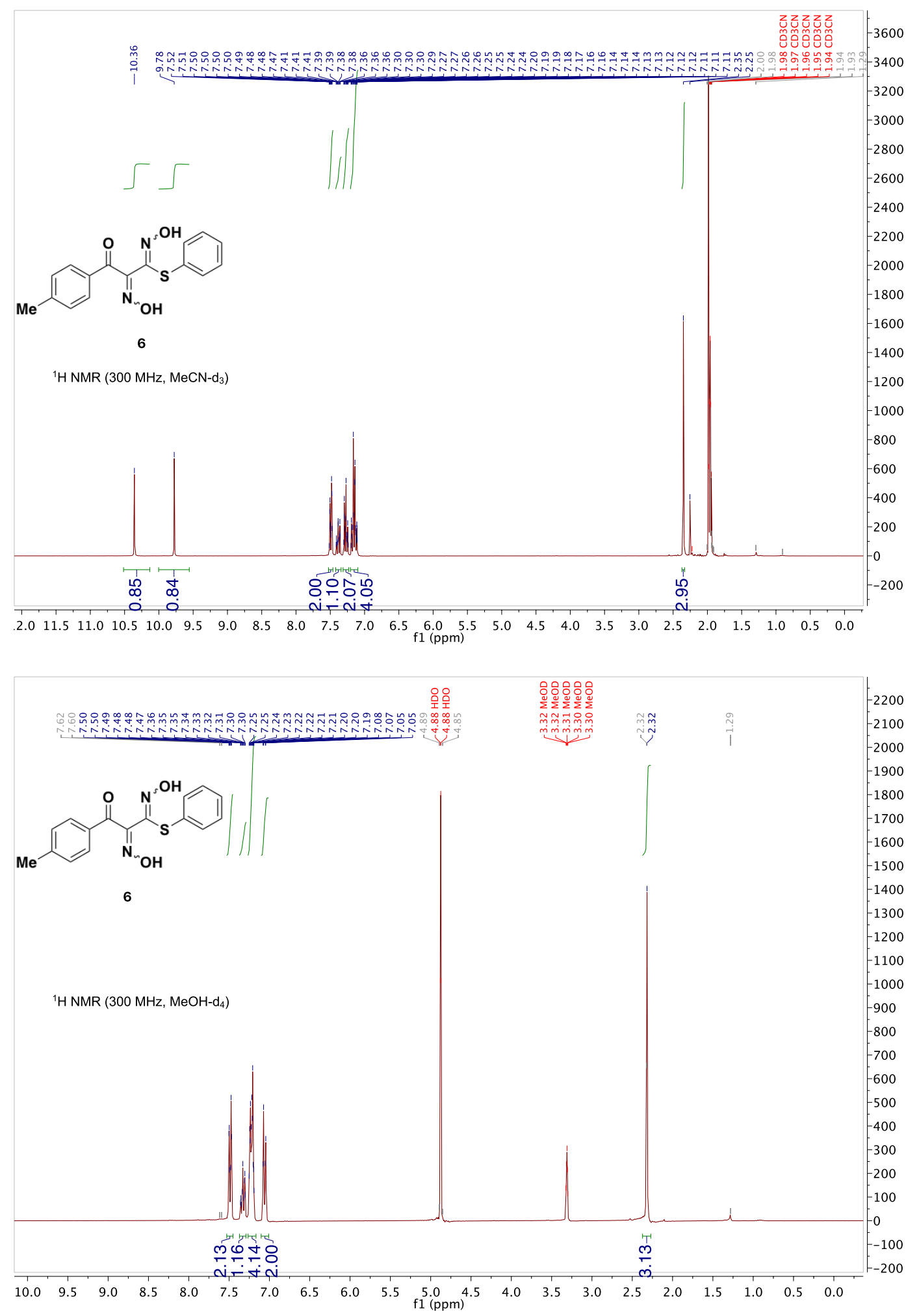

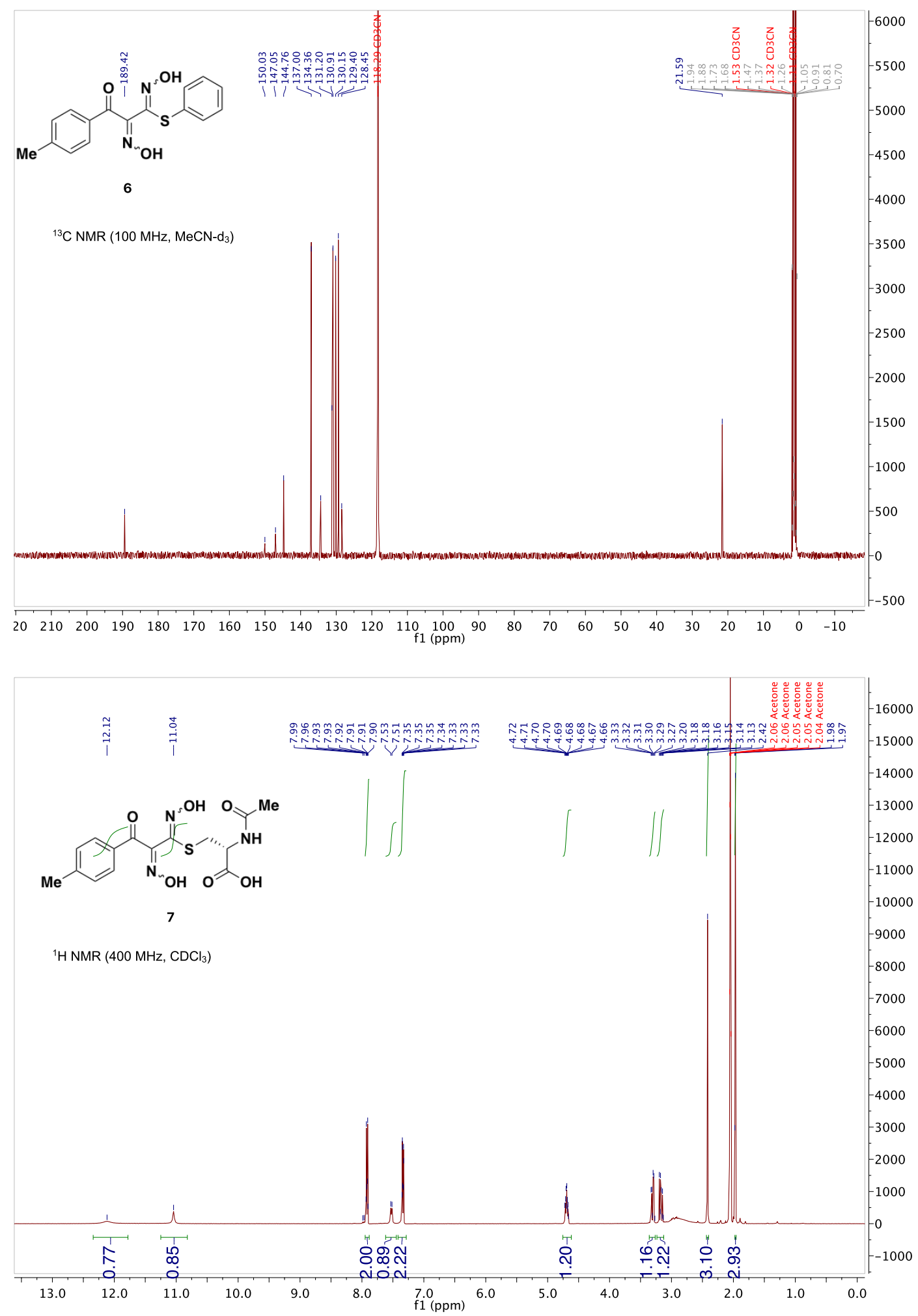


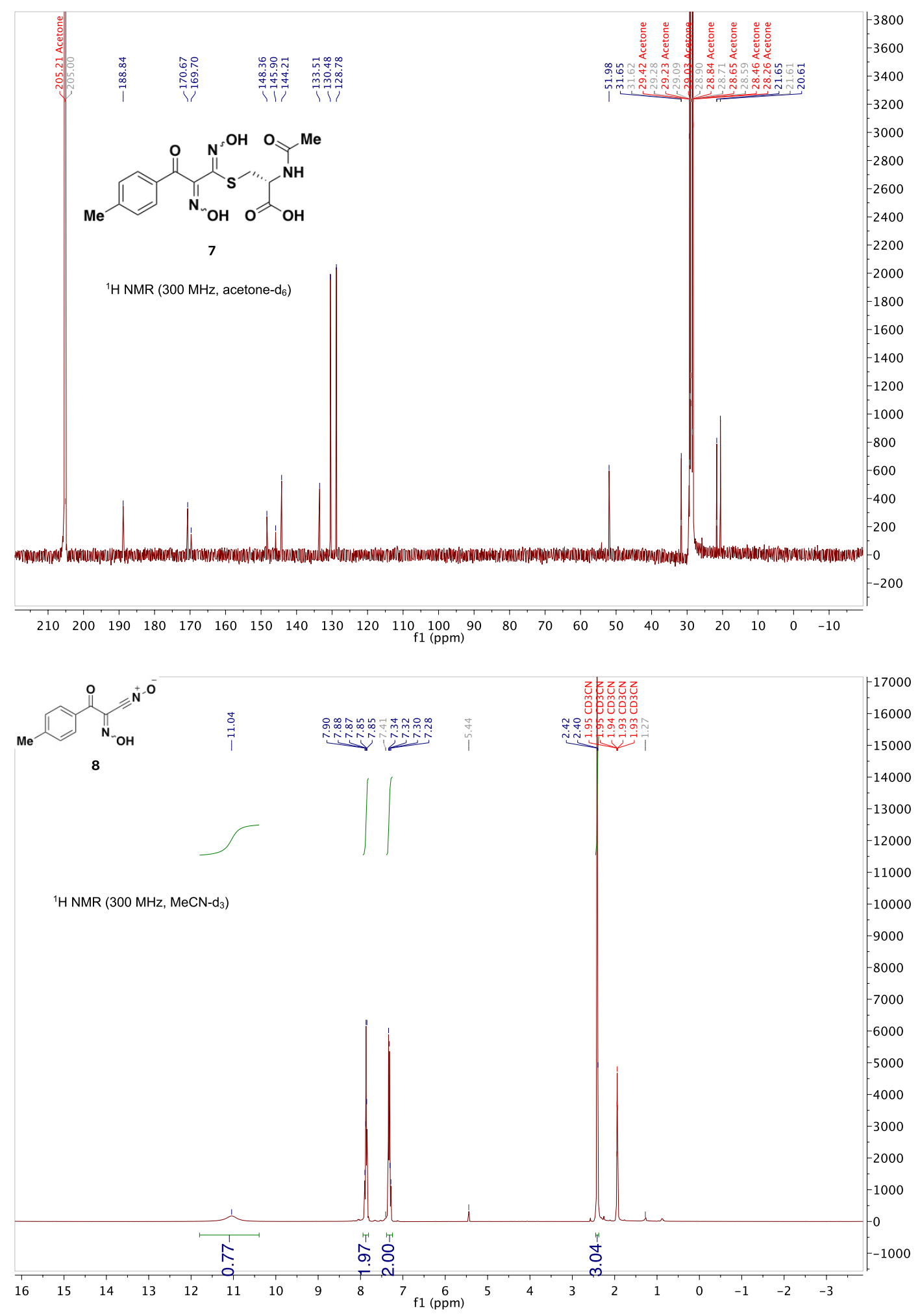




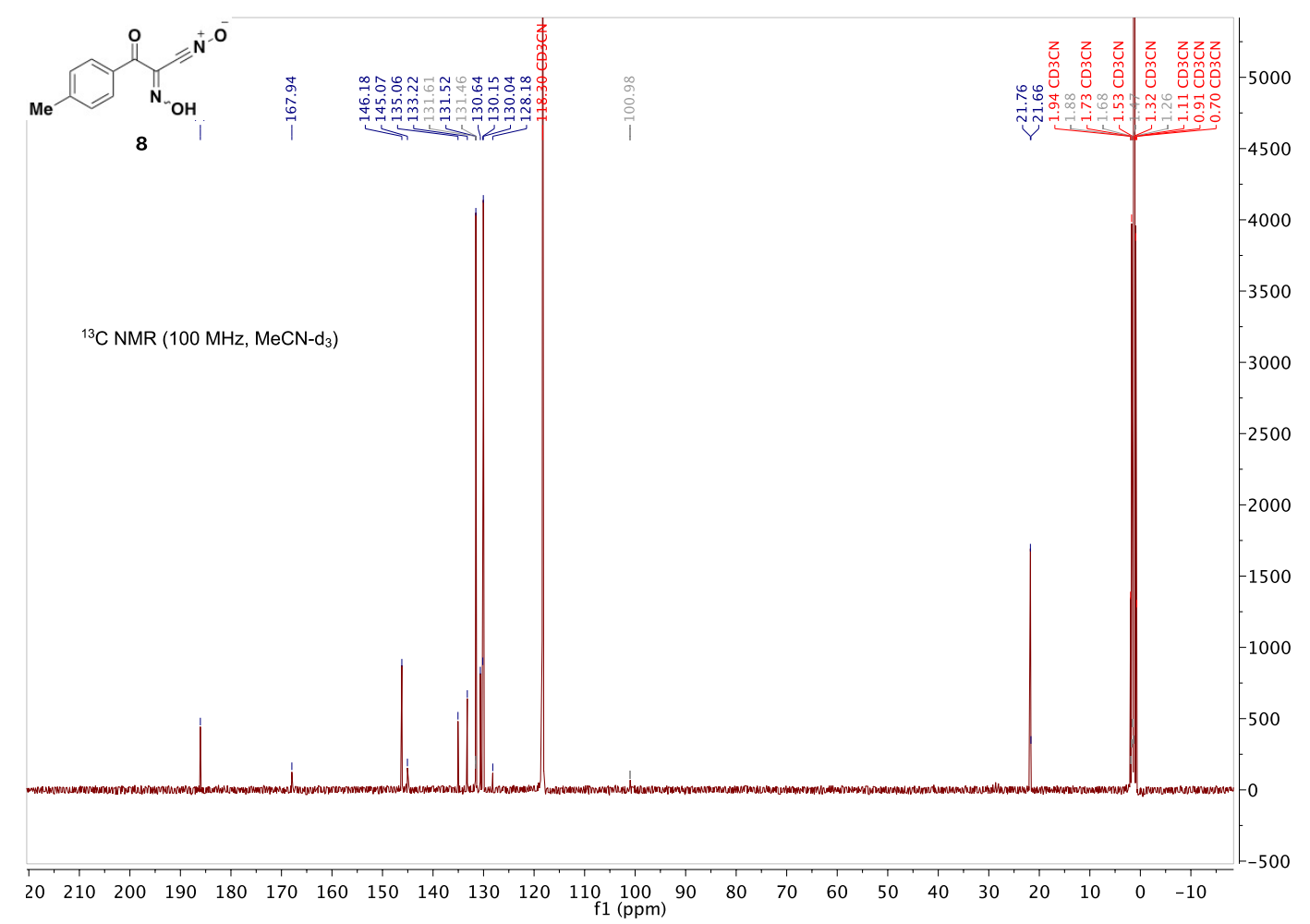

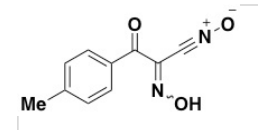

8

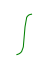

${ }^{1} \mathrm{H}$ NMR $\left(400 \mathrm{MHz}, \mathrm{DMSO}-\mathrm{d}_{6}\right)$
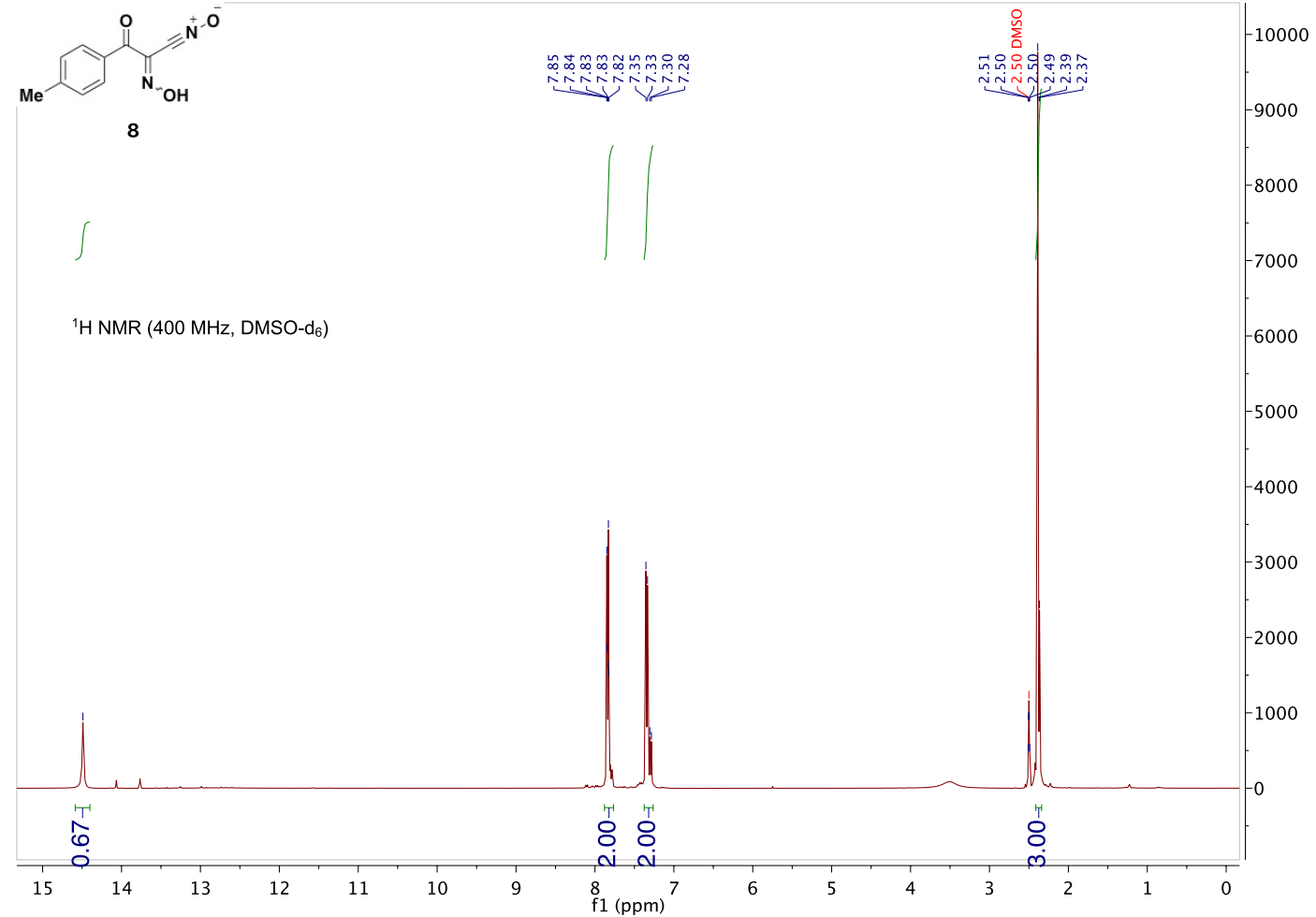

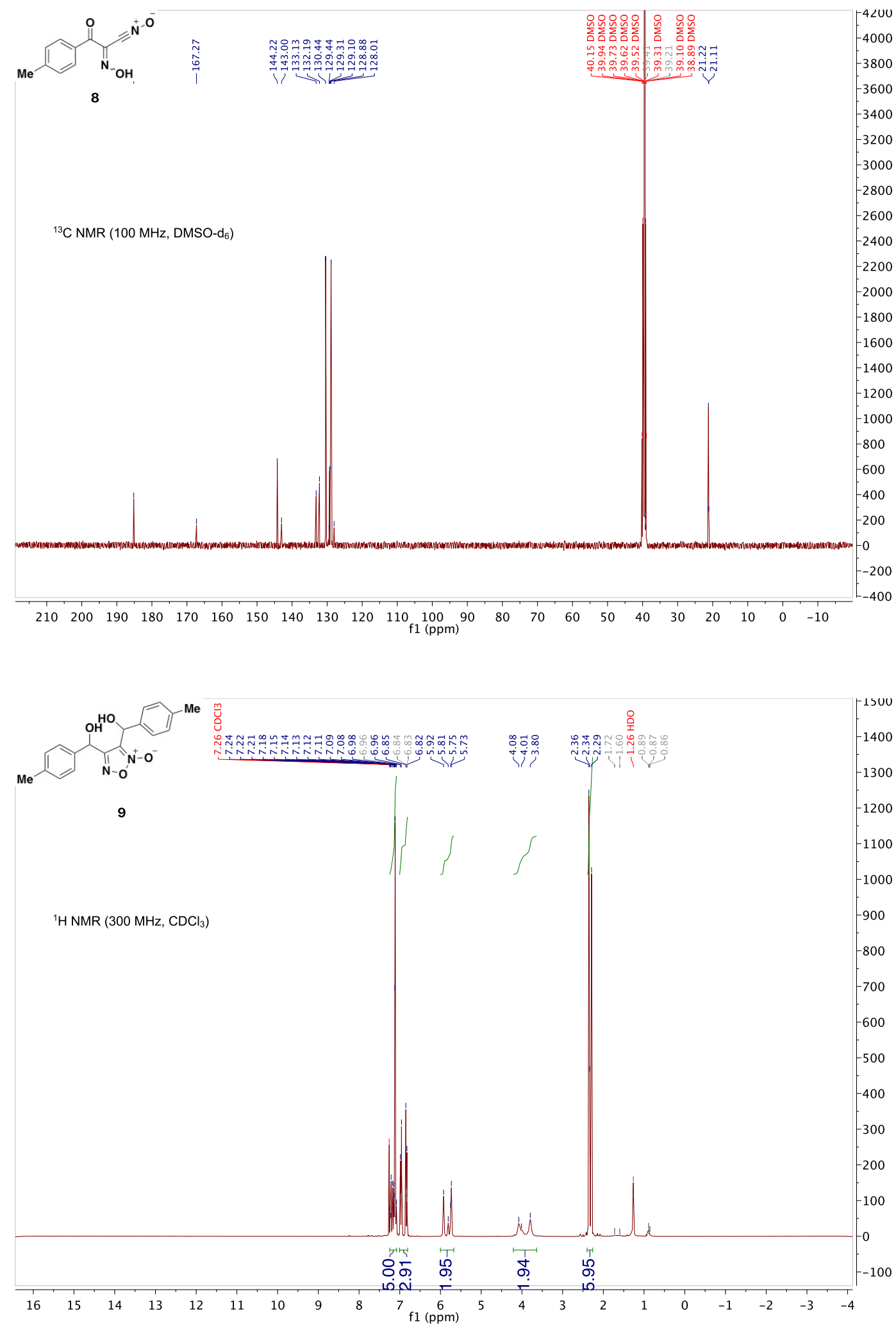

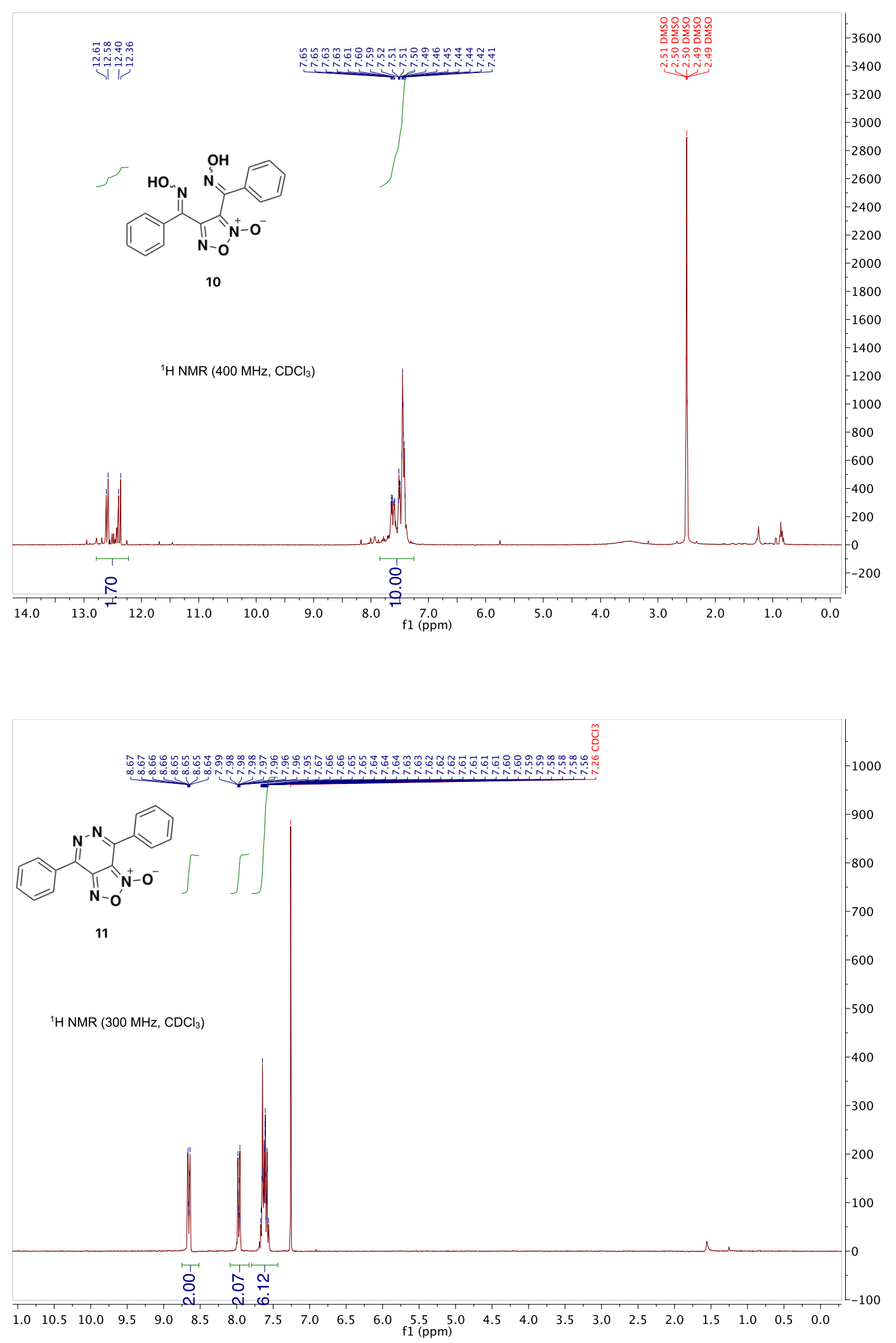

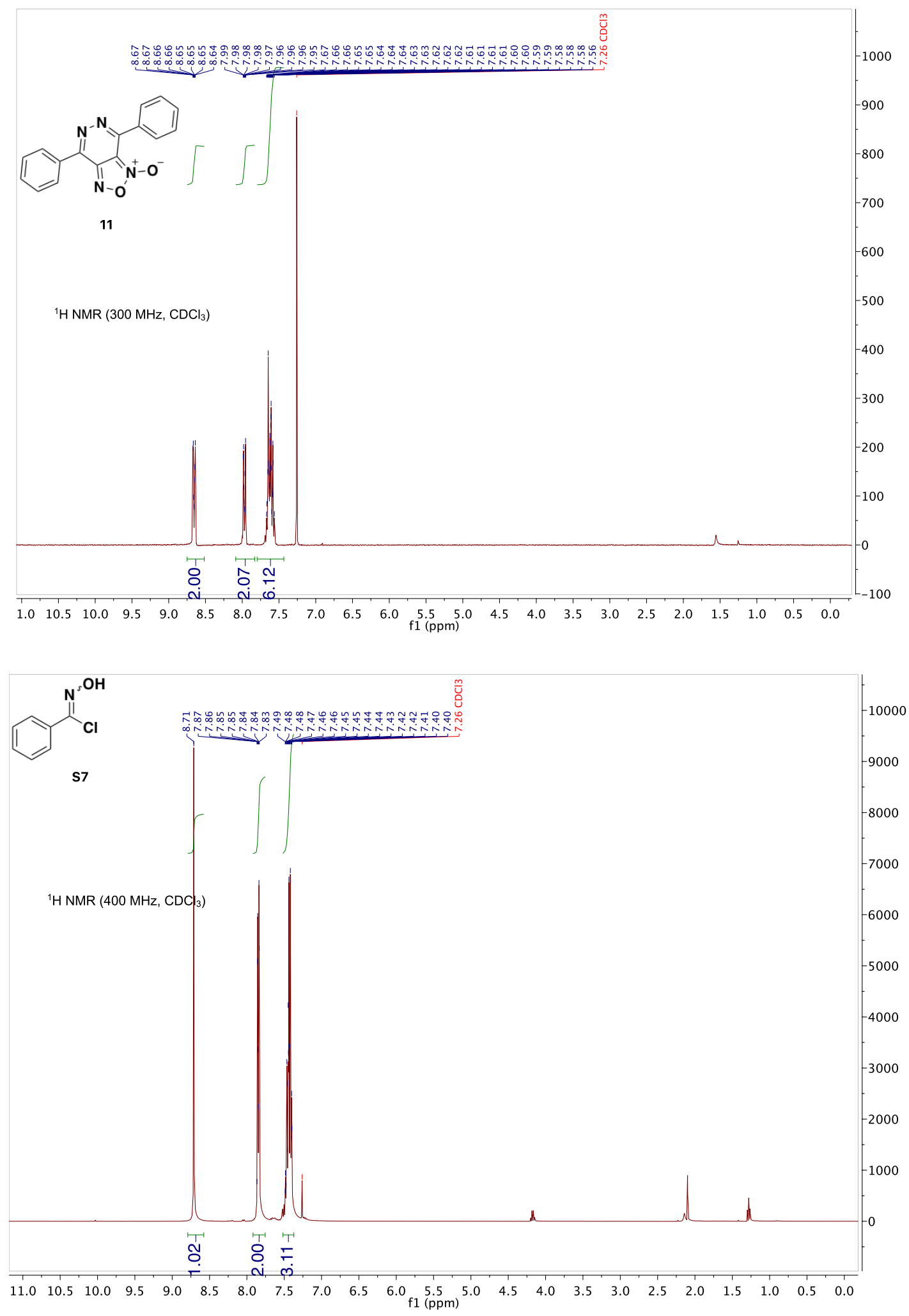

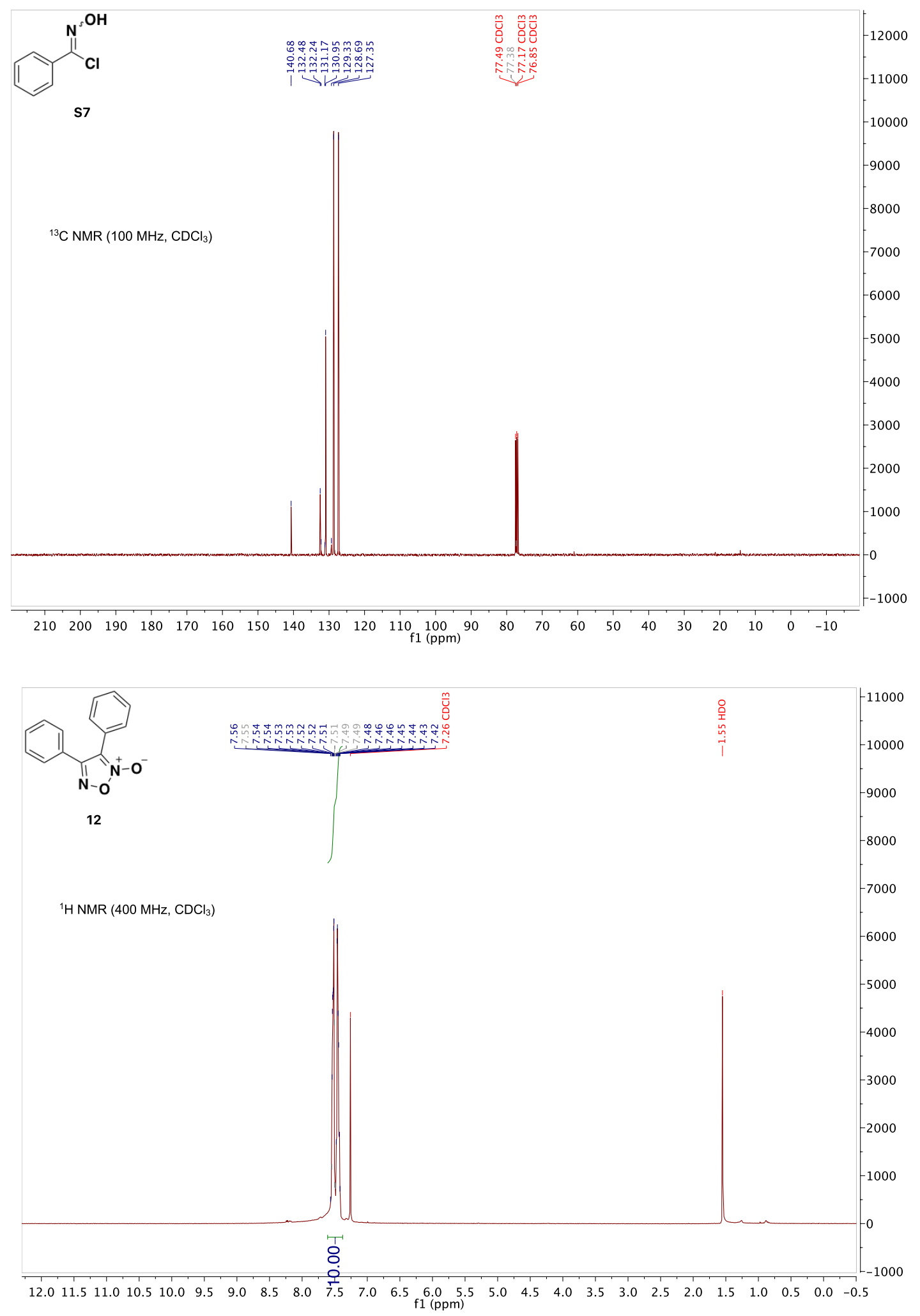


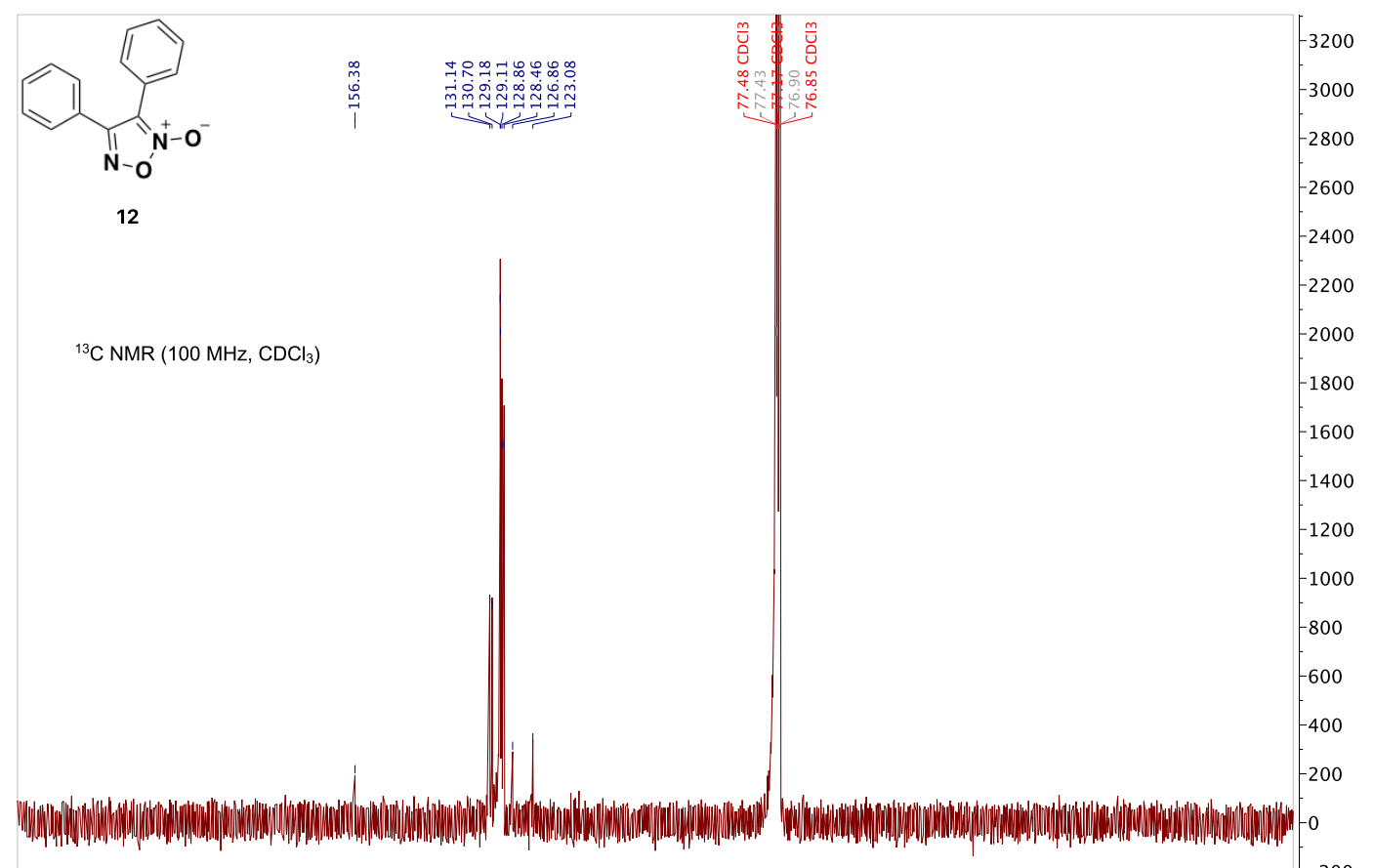

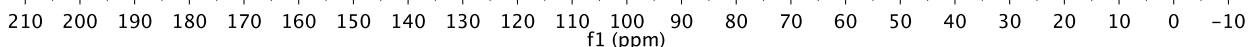

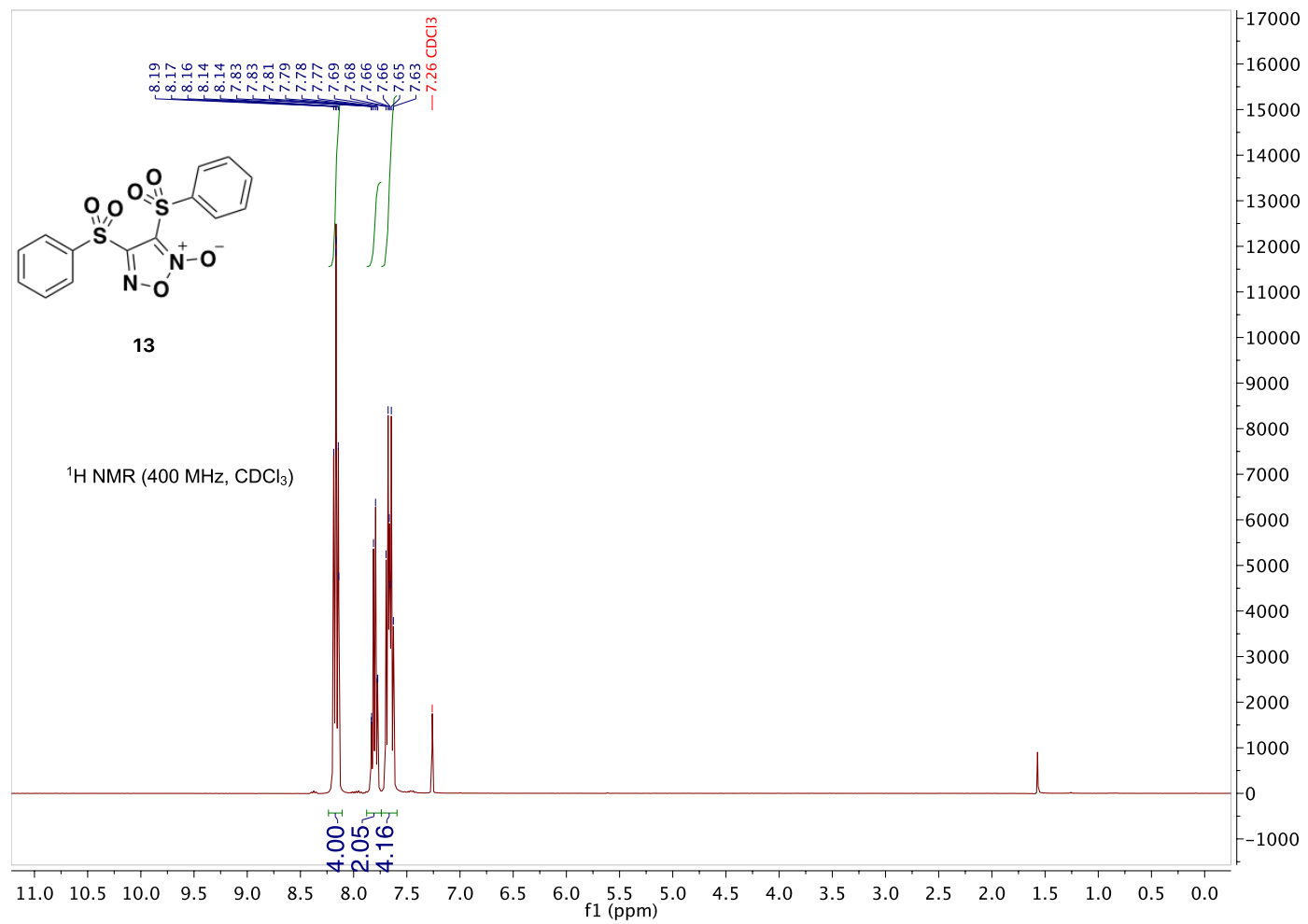



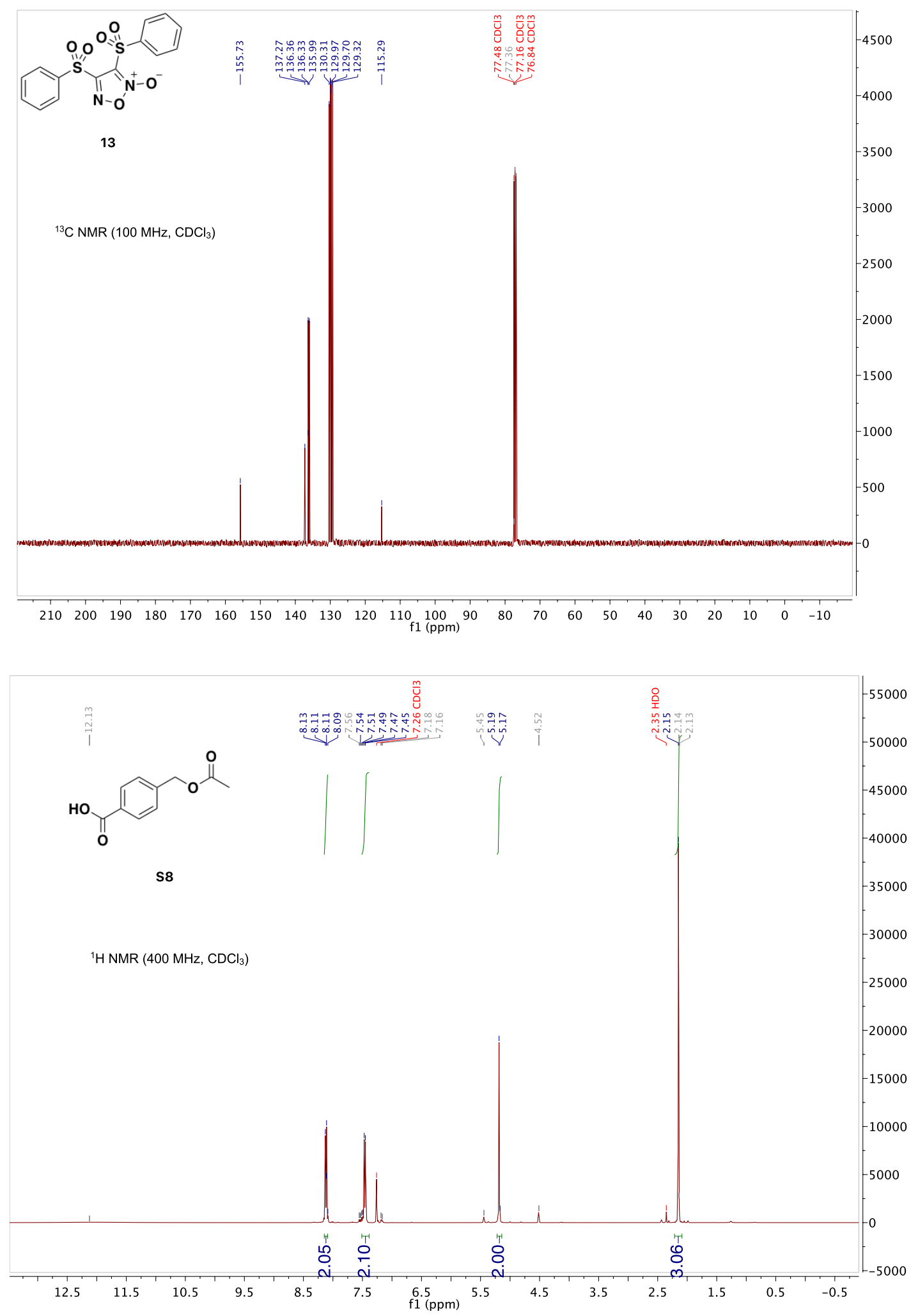

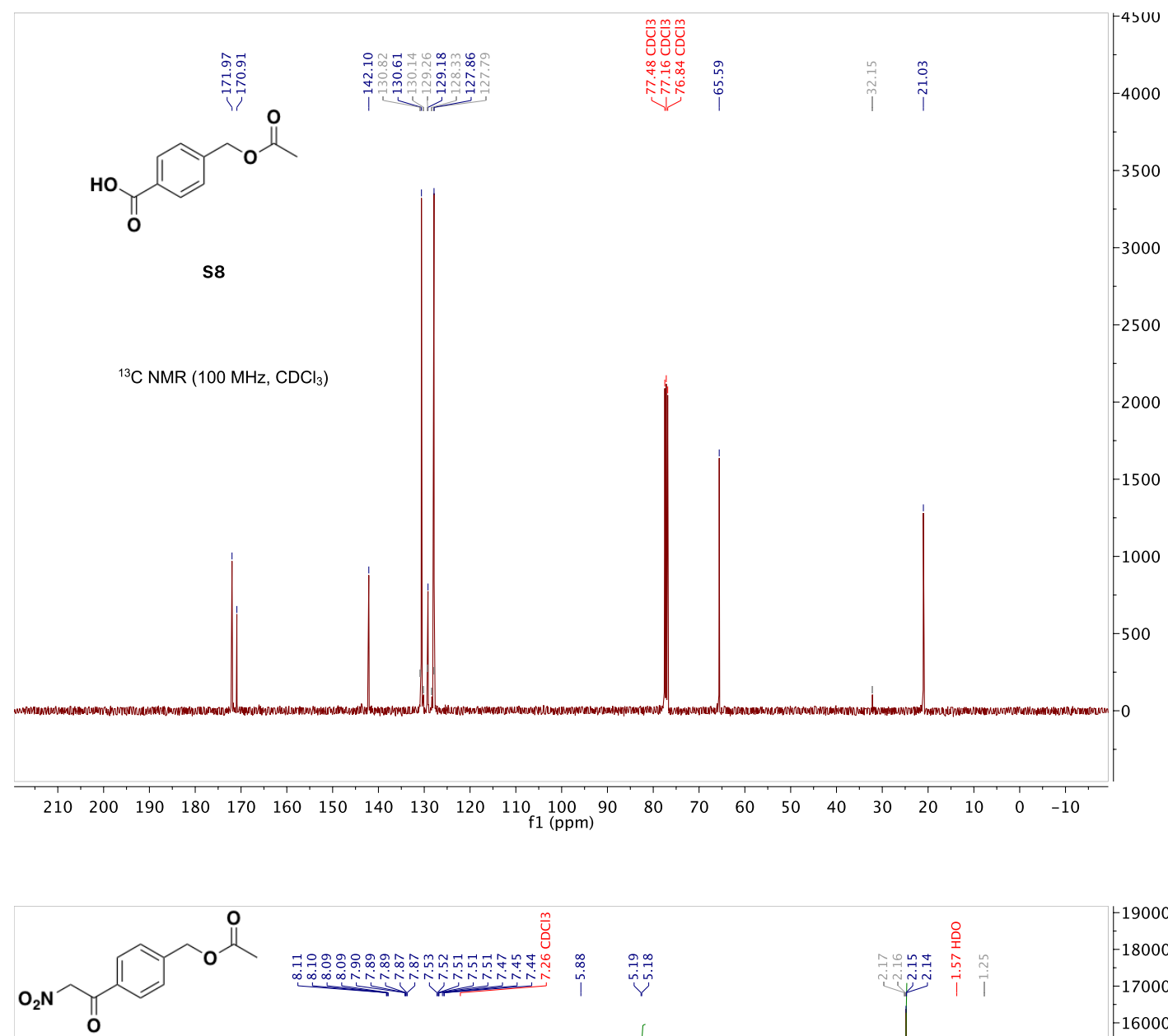

s9
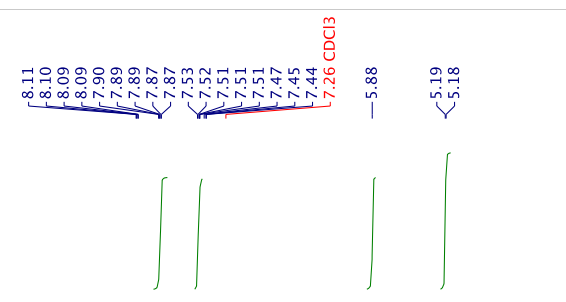

${ }^{1} \mathrm{H}$ NMR $\left(400 \mathrm{MHz}, \mathrm{CDCl}_{3}\right)$

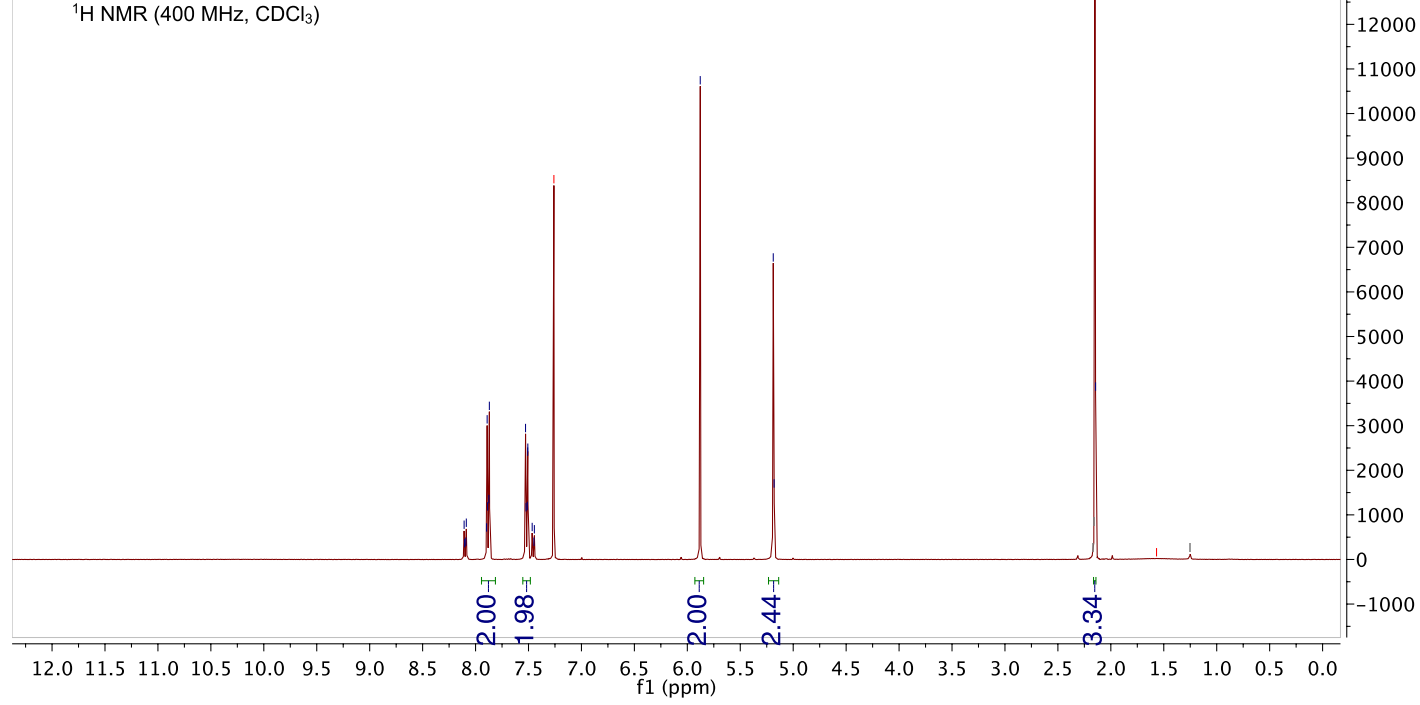



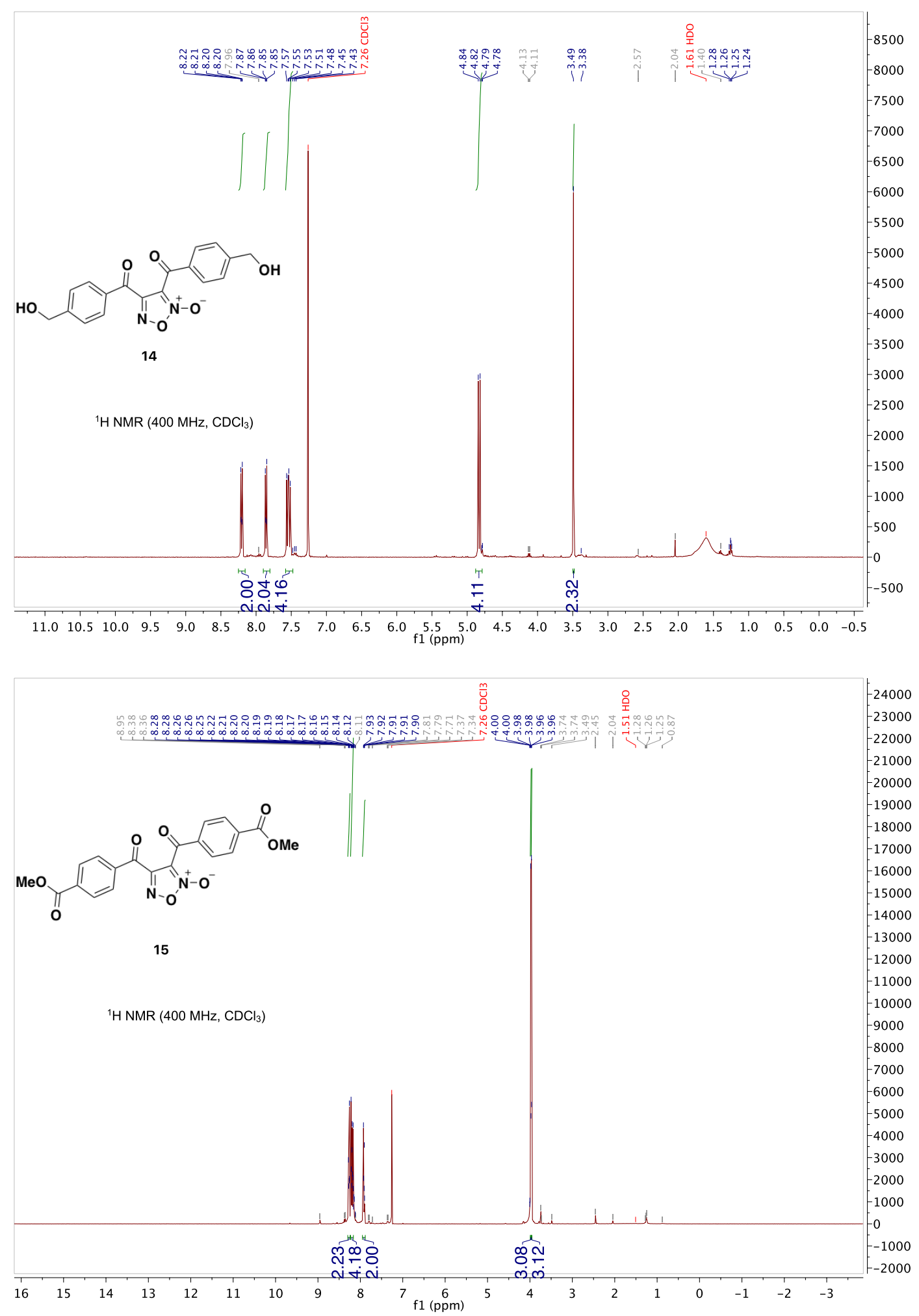

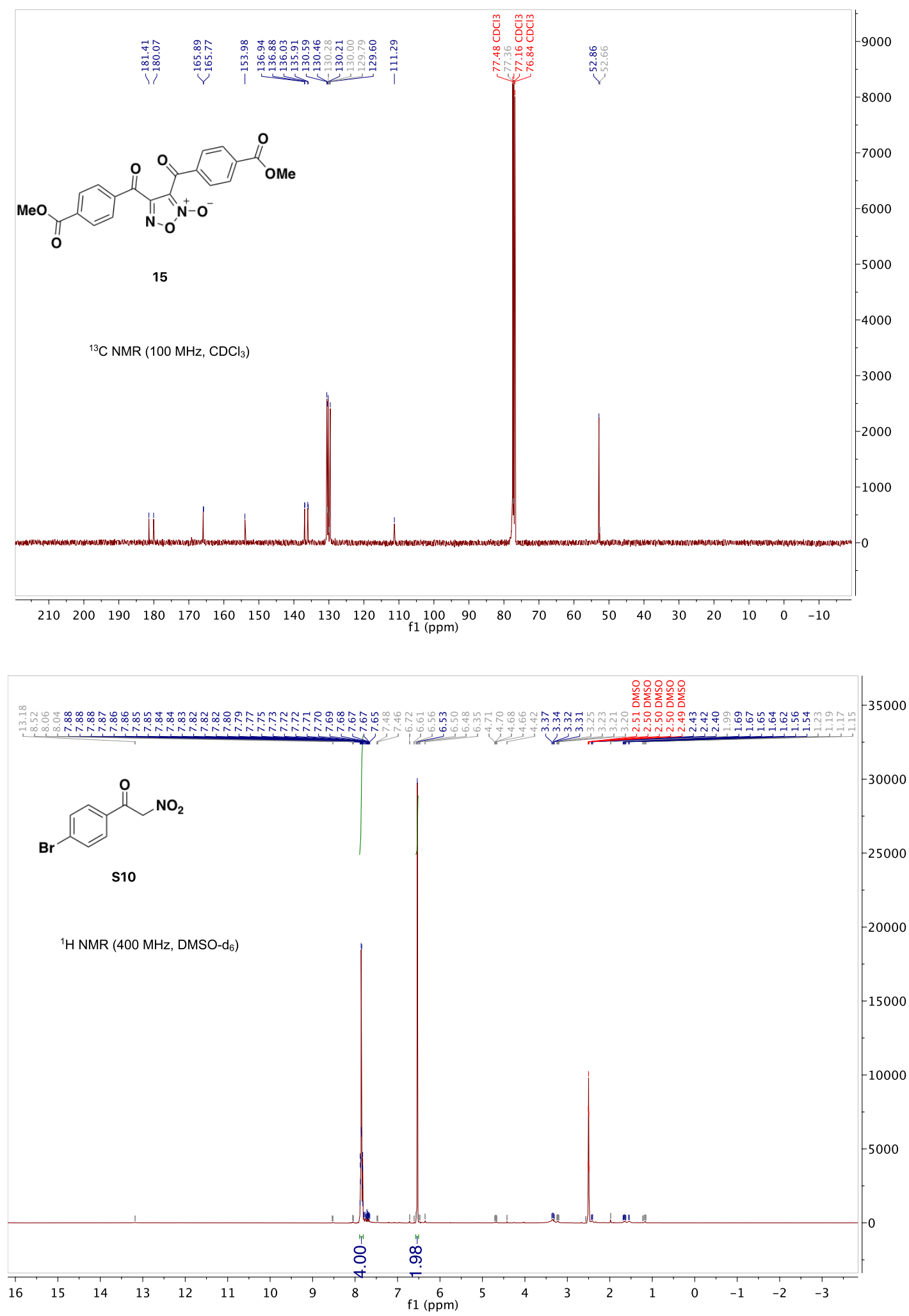

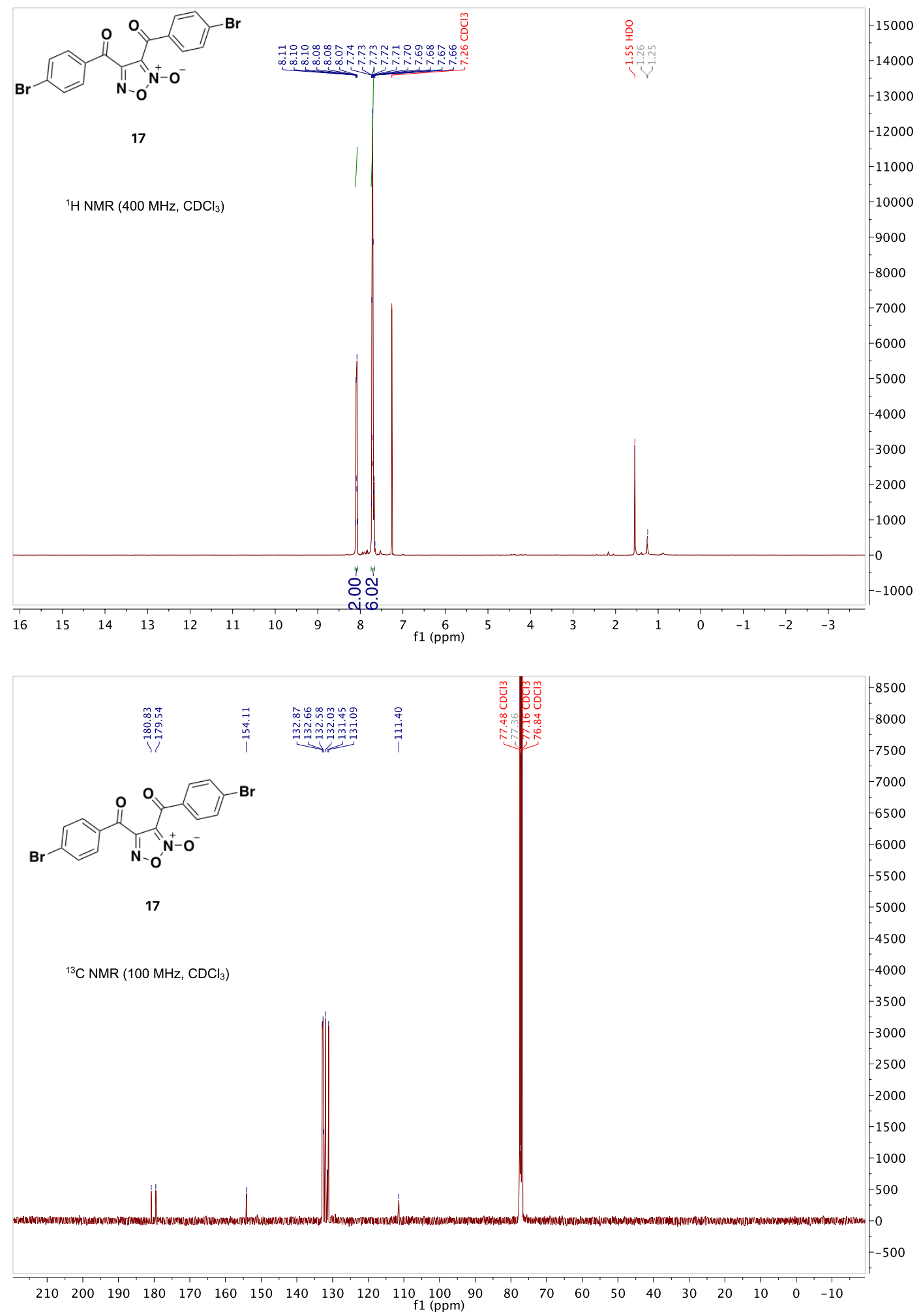

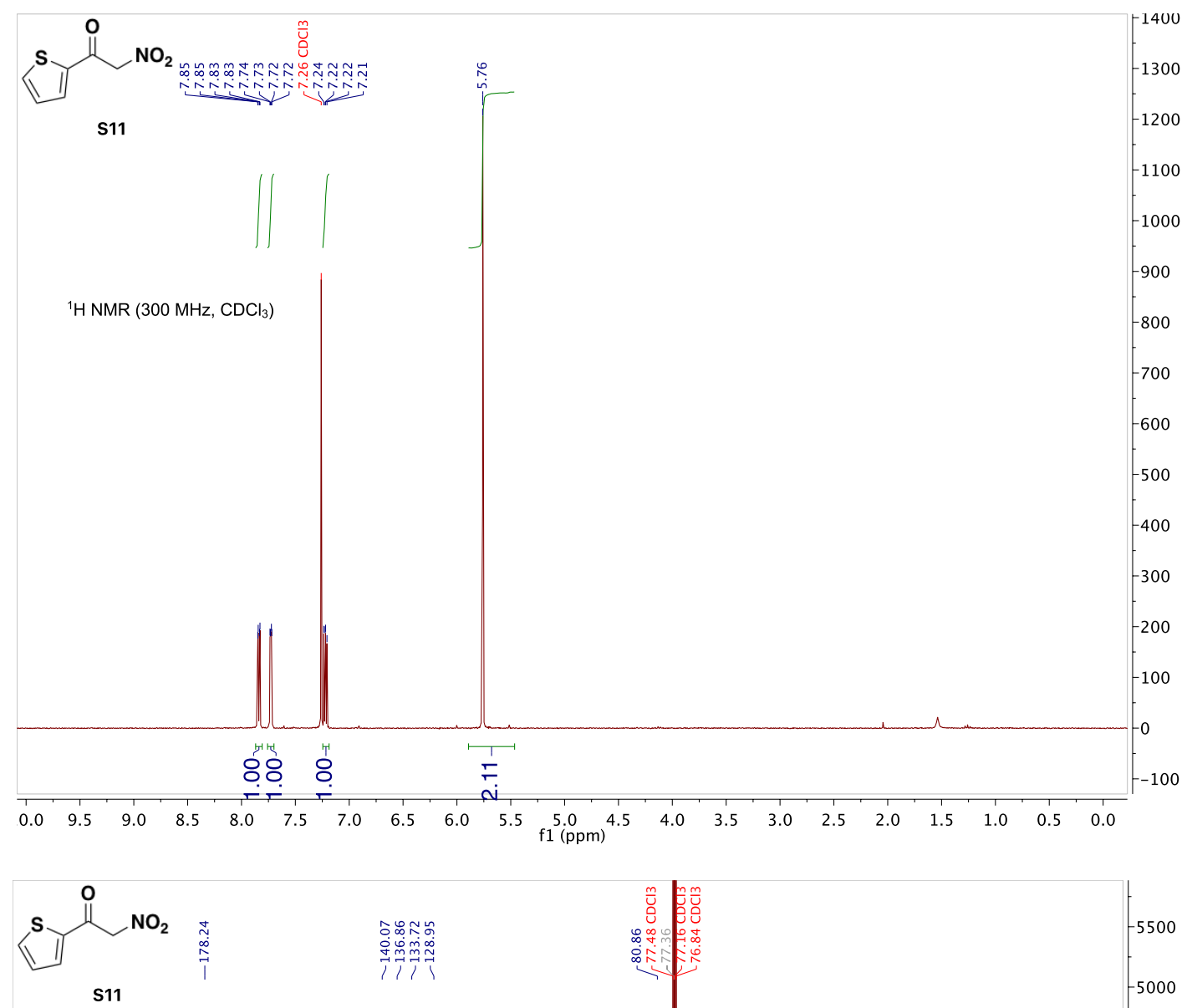

${ }^{13} \mathrm{C}$ NMR $\left(100 \mathrm{MHz}, \mathrm{CDCl}_{3}\right)$

S11
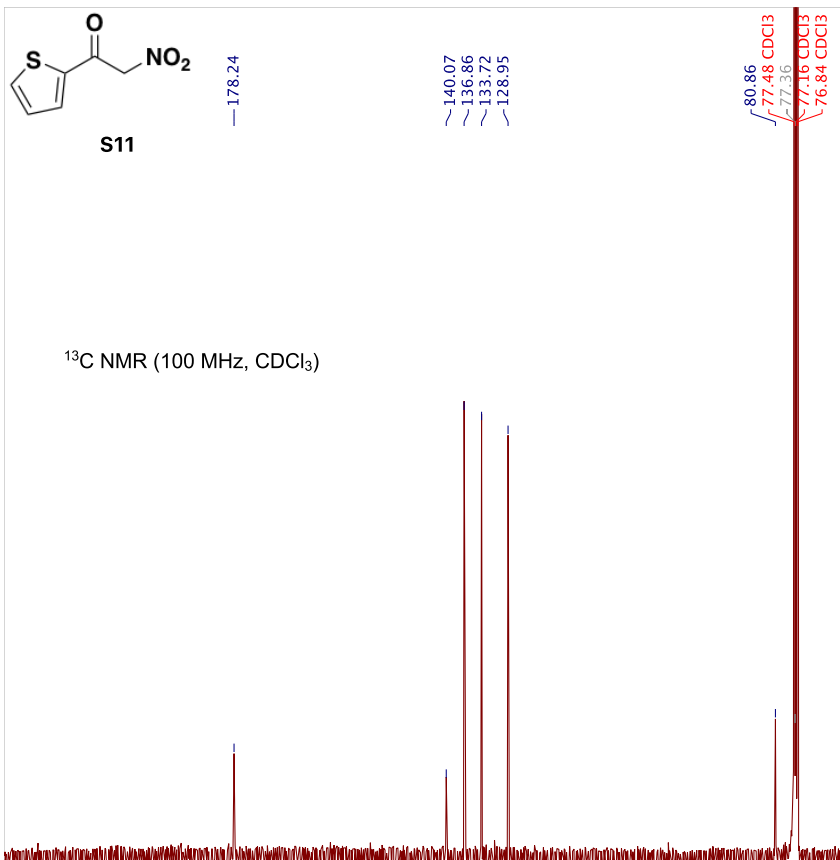

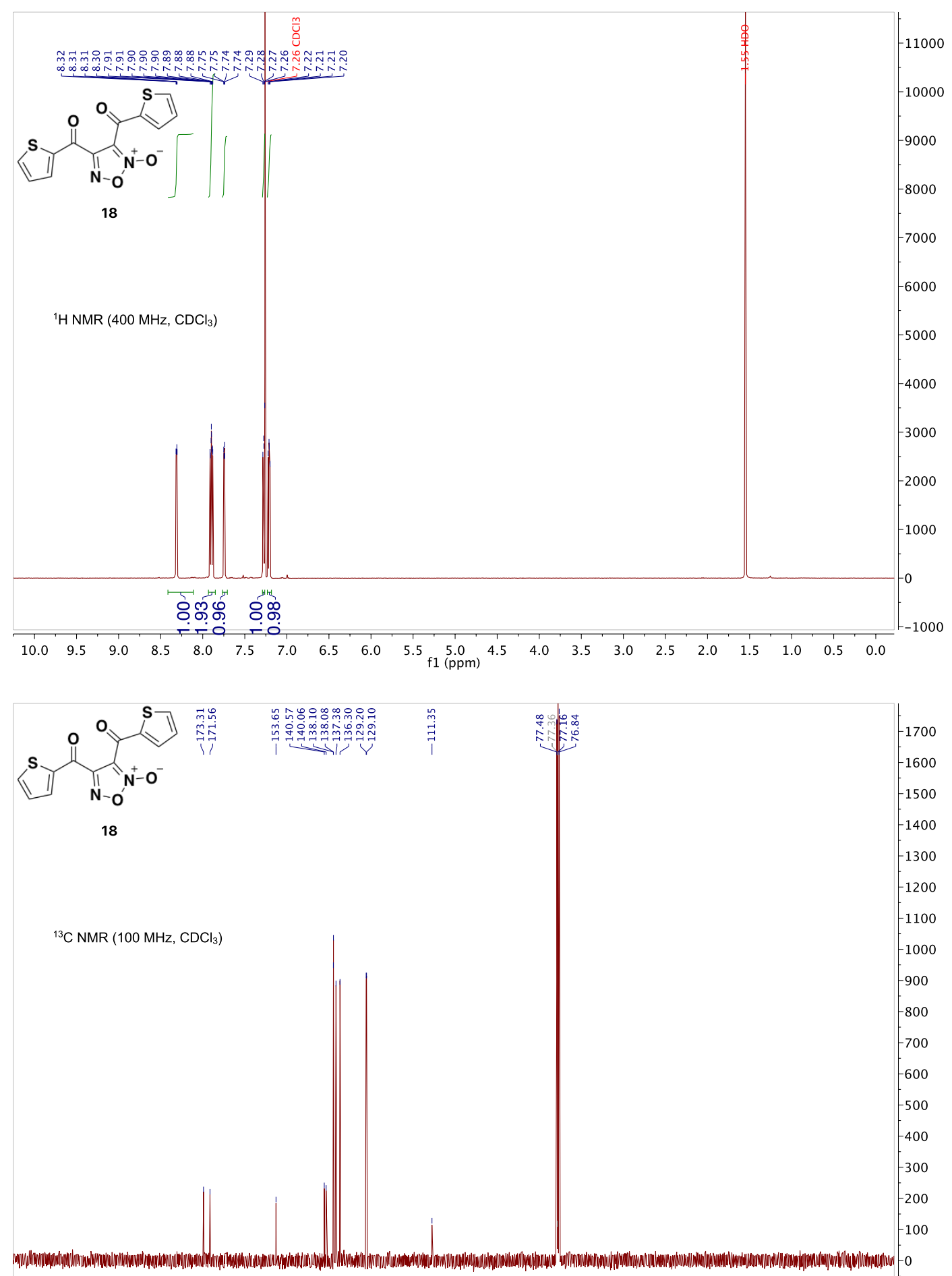

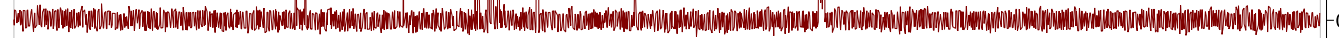

$\begin{array}{llllllllllll}220 & 210 & 200 & 190 & 180 & 170 & 160 & 150 & 140 & 130 & 120 & \begin{array}{l}110 \\ \mathrm{f} 1(\mathrm{ppm})\end{array}\end{array}$ 

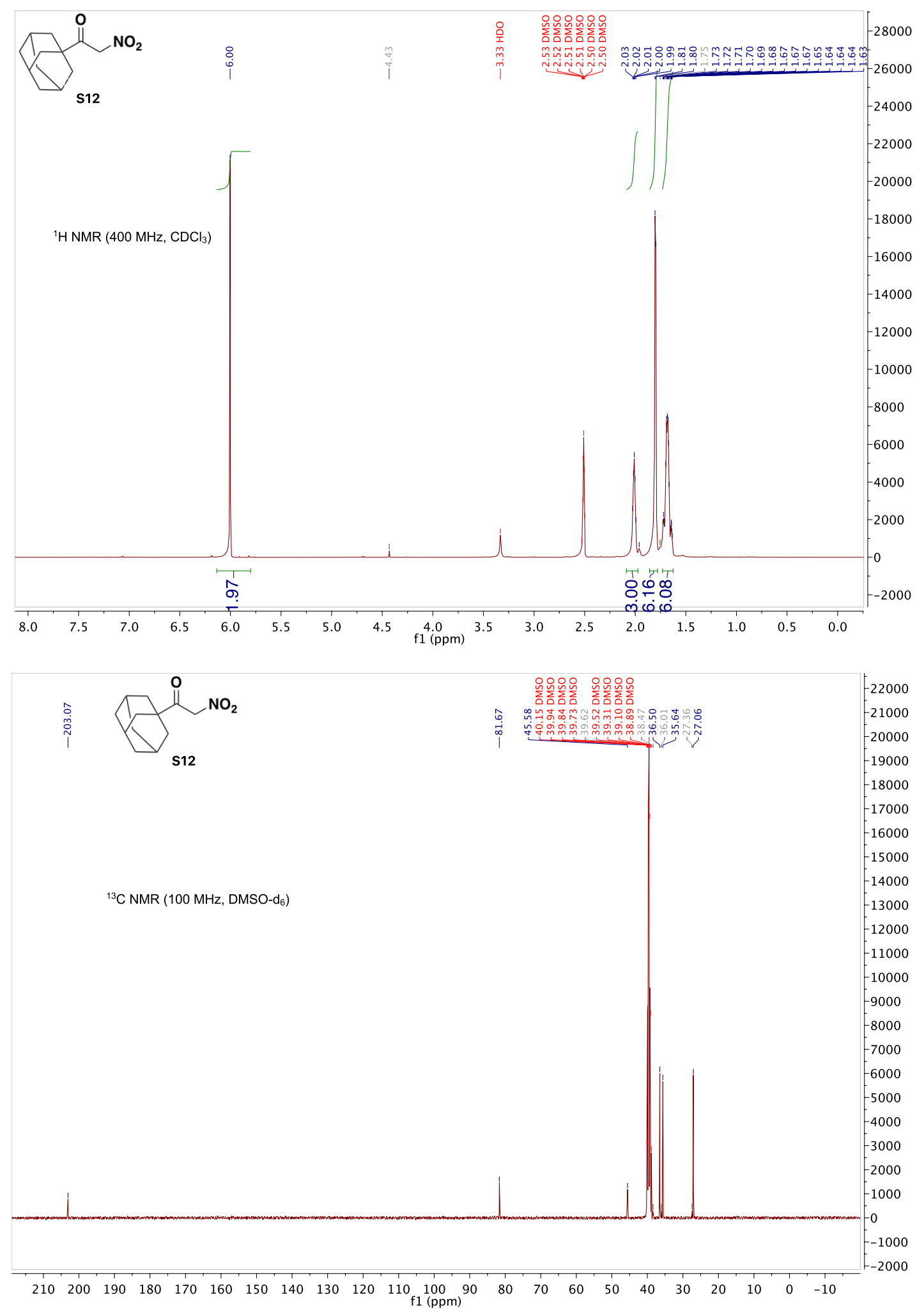


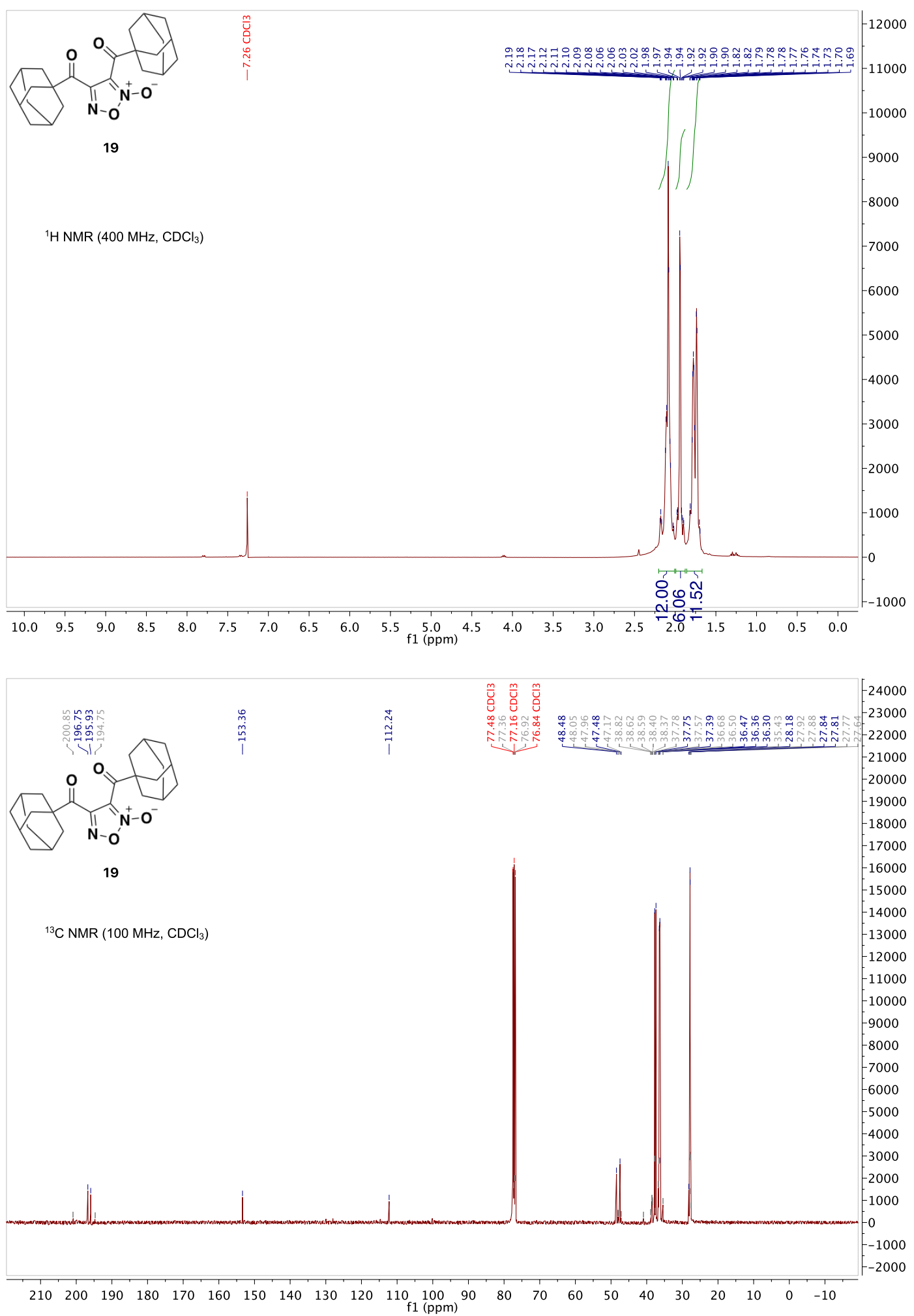



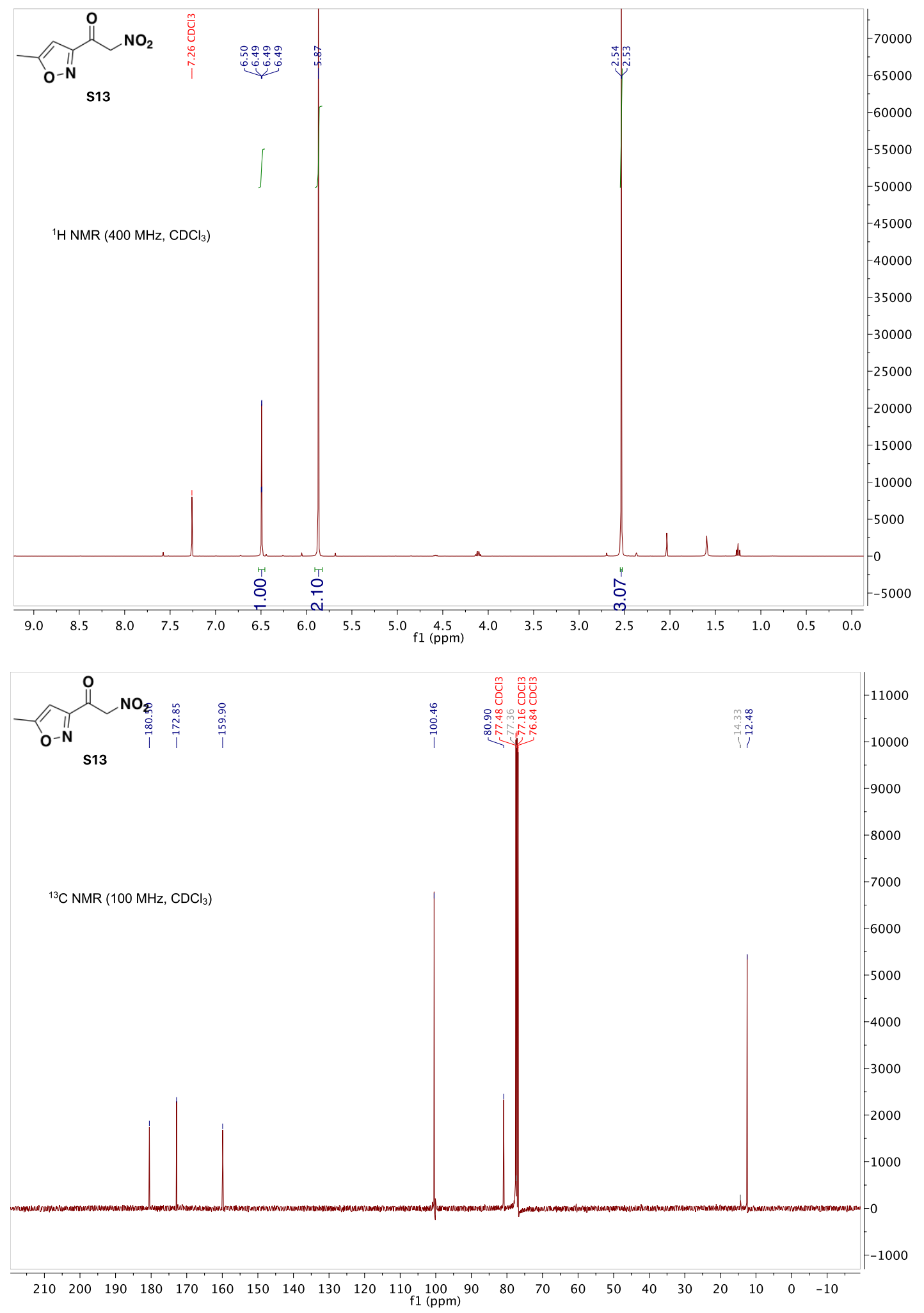

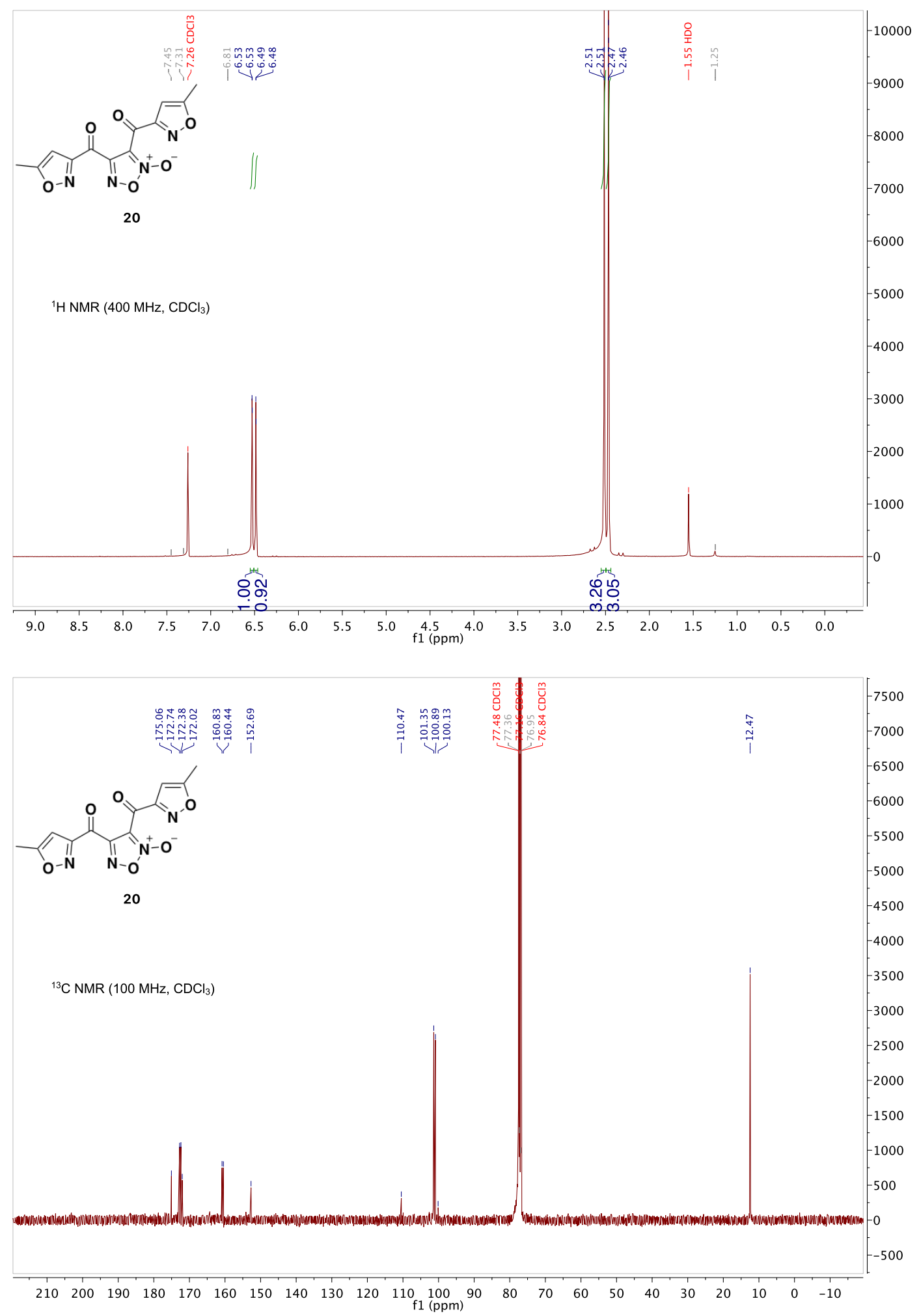

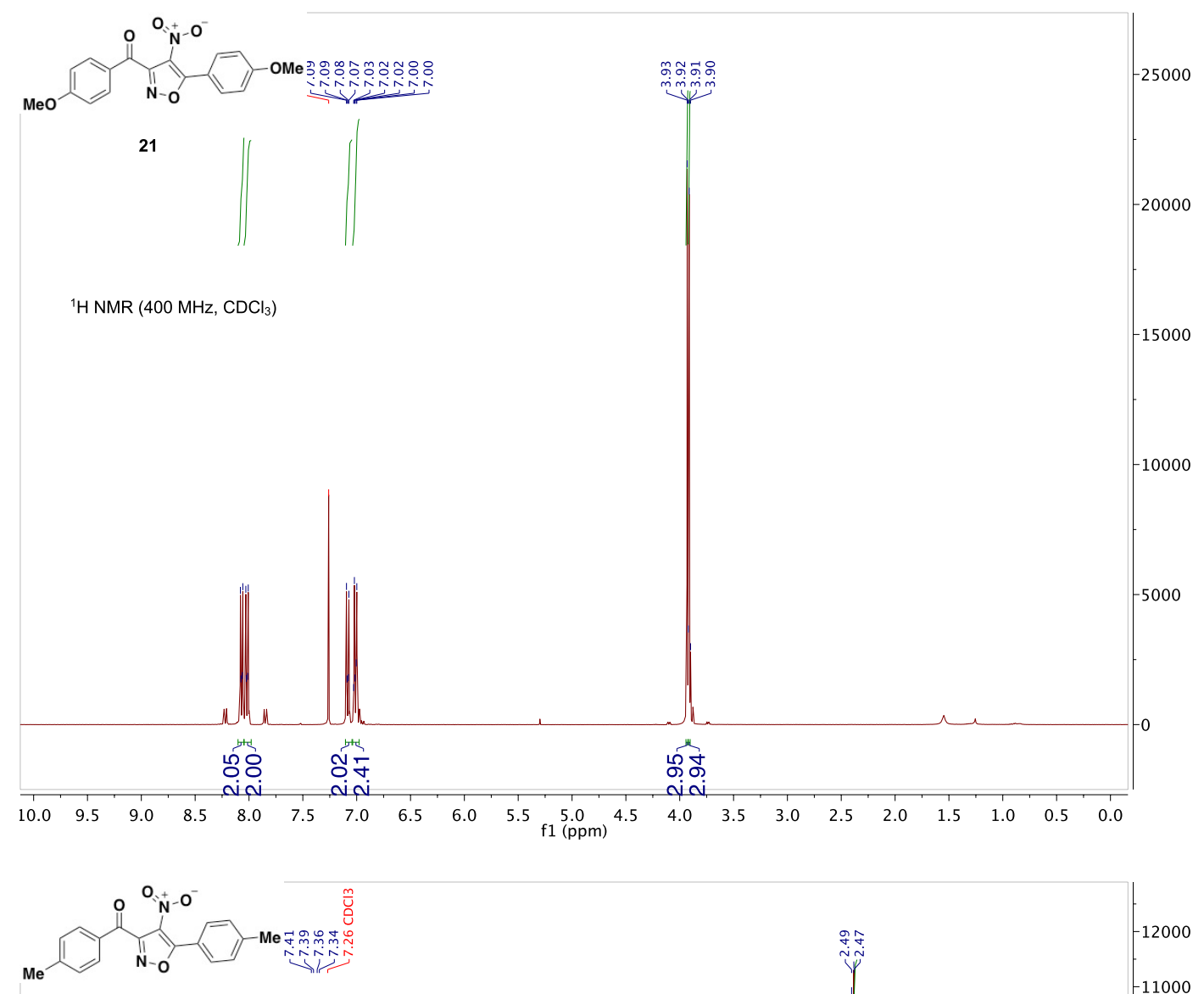

22

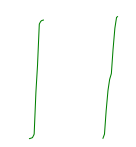

${ }^{1} \mathrm{H} \mathrm{NMR}\left(400 \mathrm{MHz}, \mathrm{CDCl}_{3}\right)$

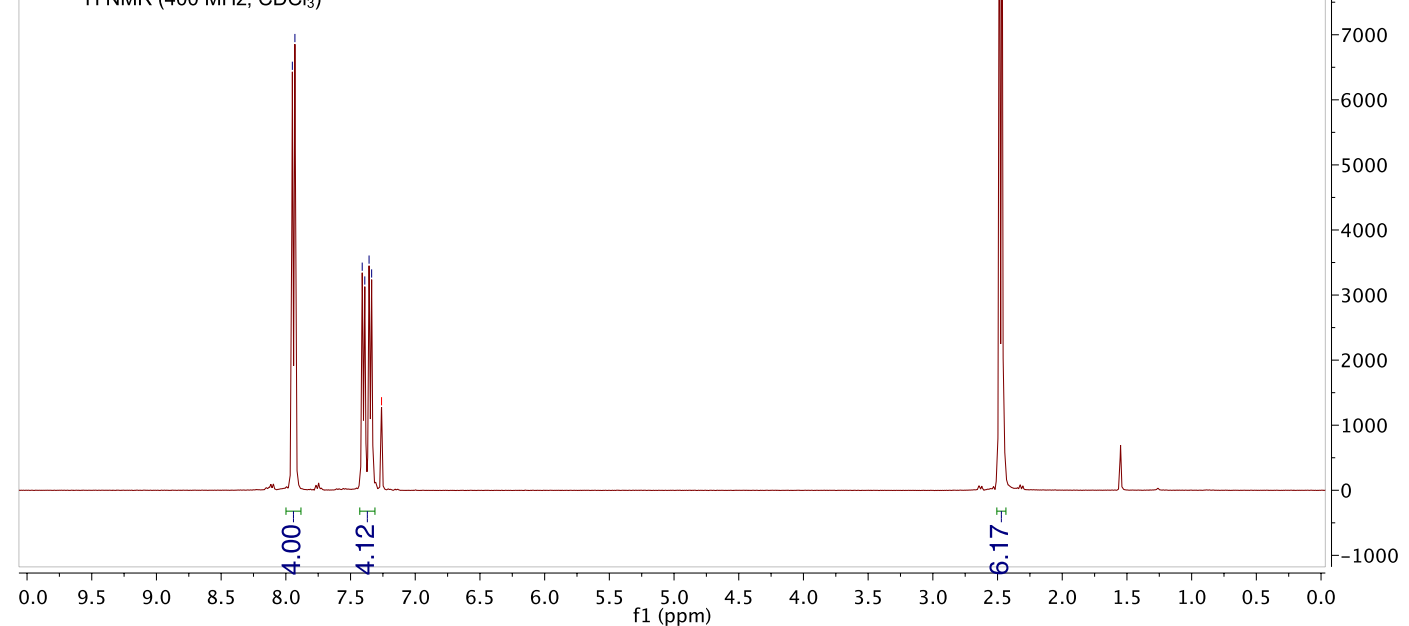



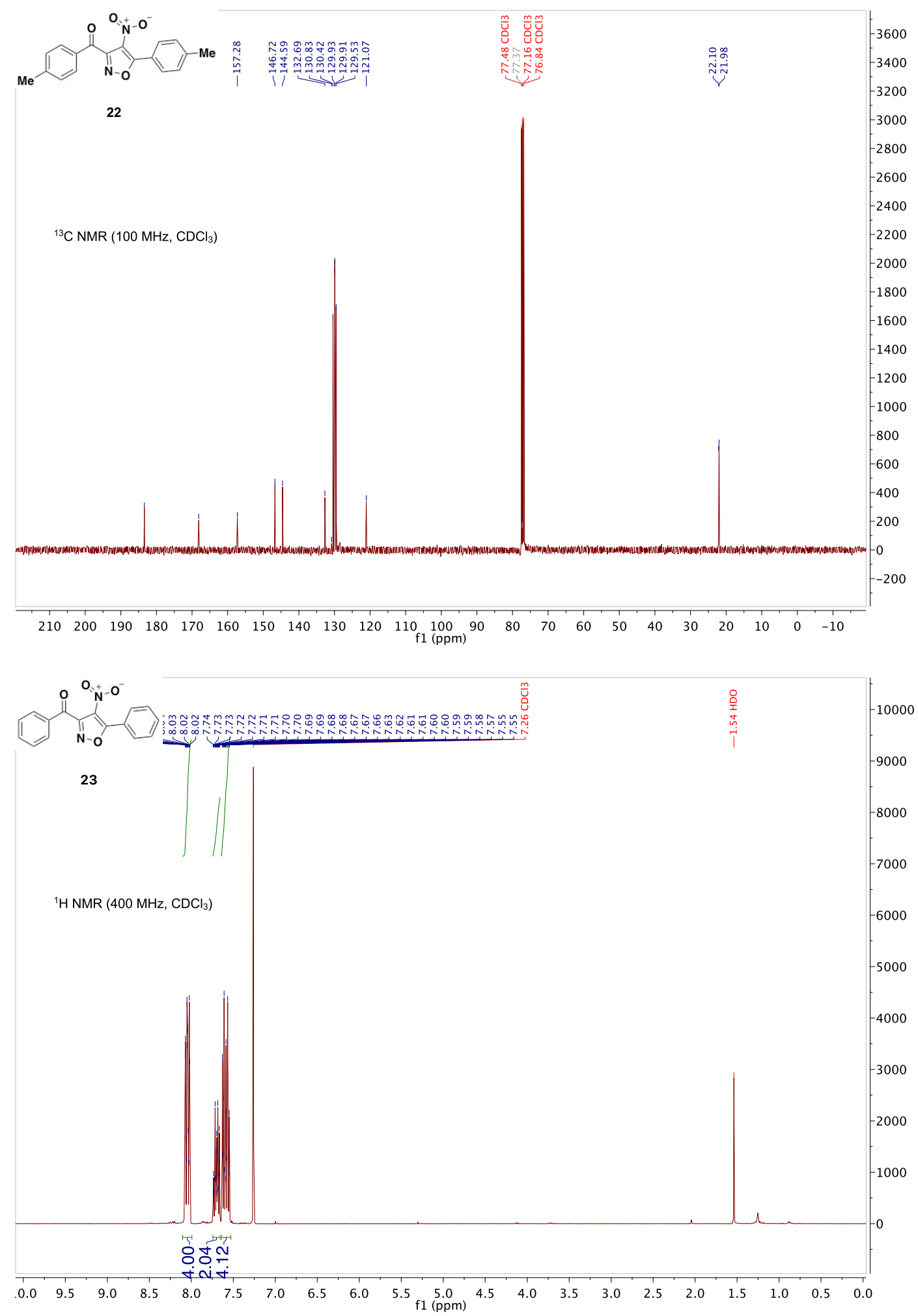


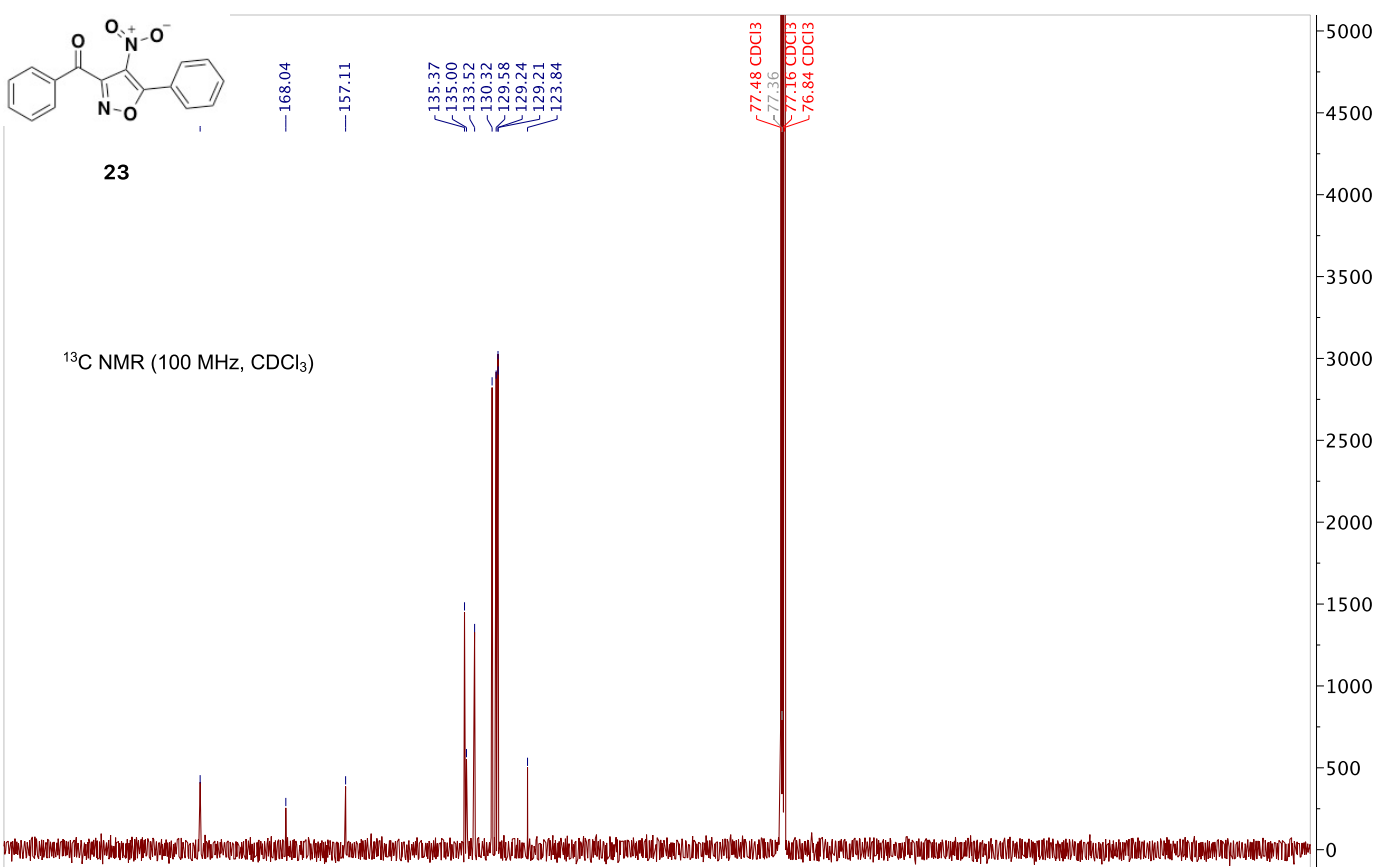

$\begin{array}{llllllllllllllllllllllll}210 & 200 & 190 & 180 & 170 & 160 & 150 & 140 & 130 & 120 & 110 & 100 & 90 & 80 & 70 & 60 & 50 & 40 & 30 & 20 & 10 & 0 & -10\end{array}$

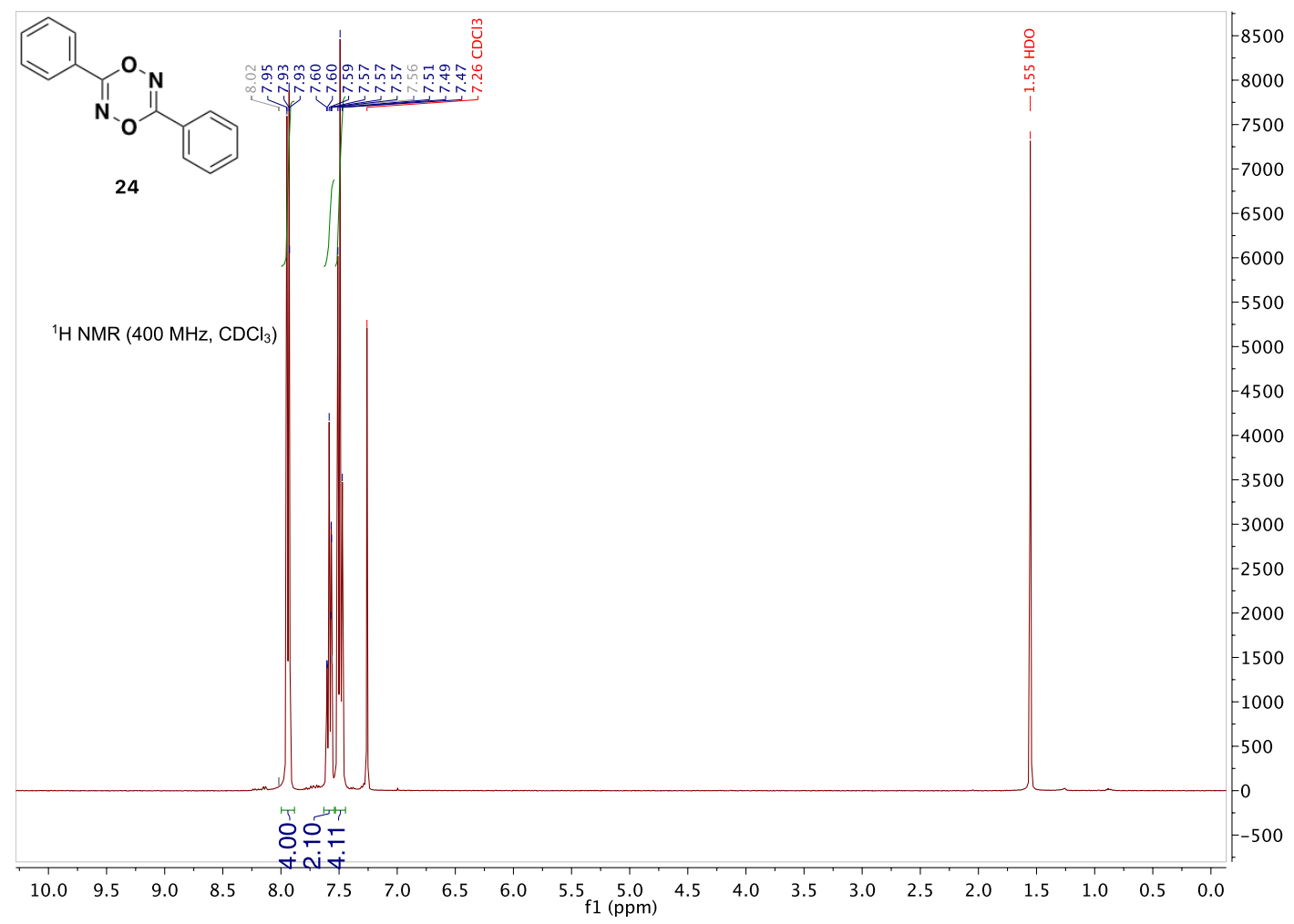




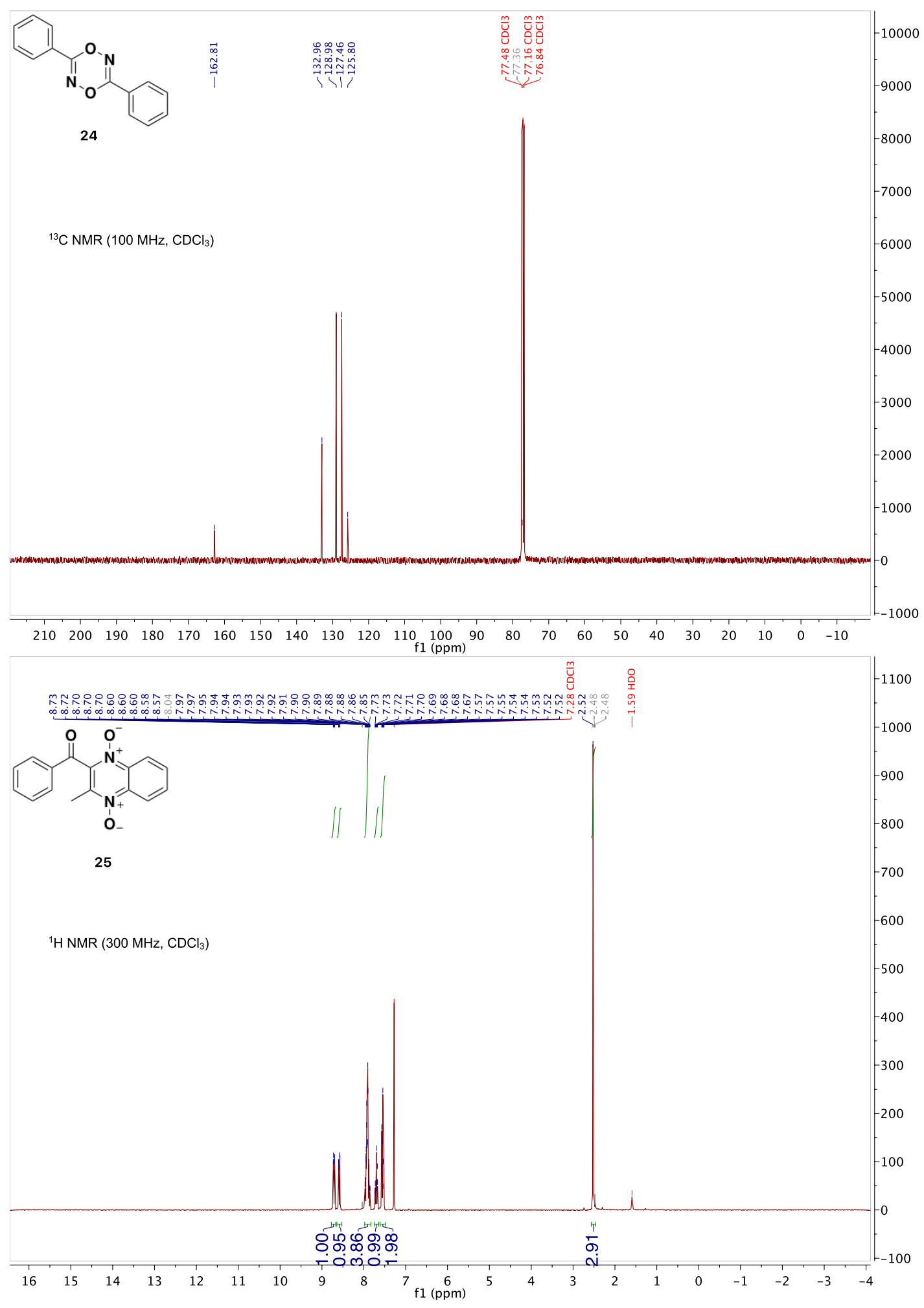




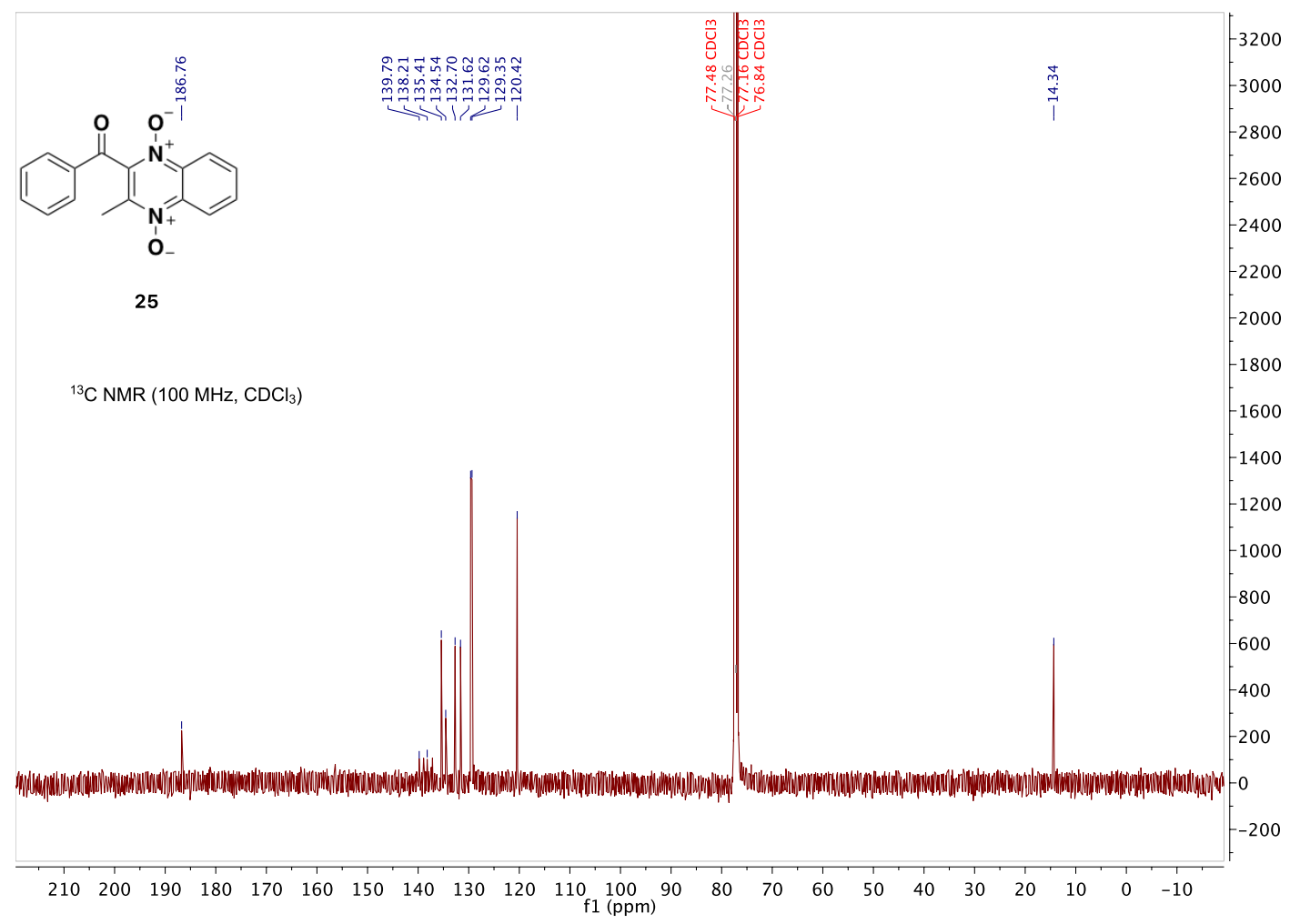

